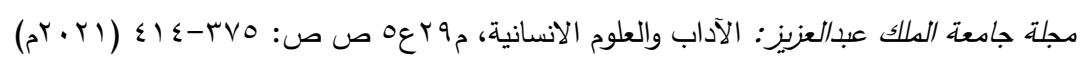

DOI:10.4197/Art.29-5.13

\title{
أحكام وآداب المزاح في الشريعة الإسلامية
}

\author{
د. إنصاف حمزة الفعر الثريف \\ أستاذ مشارك \\ قسم المواد العامة - كلية الآداب والعلوم الإنسانية \\ جامعة الملك عبدالعزيز
}

مستخلص. هدف البحث عرض أحكام وآداب المزاح في الثريعة الإسلامية، وتم استخدام المنهج الاستنباطي، وجاء

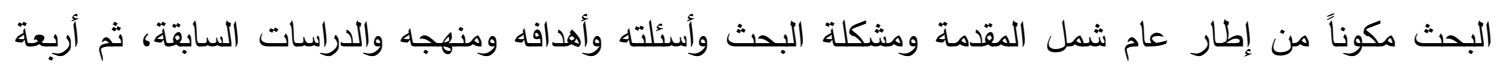

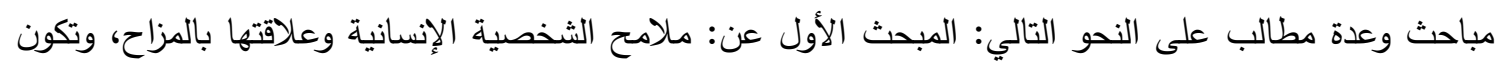

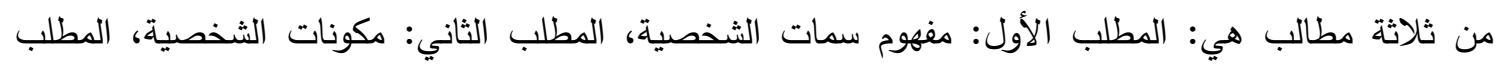

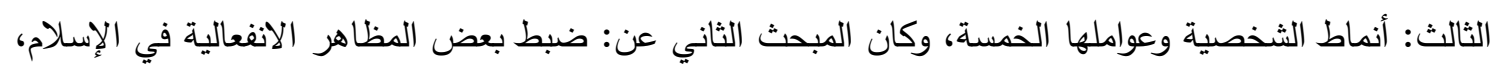

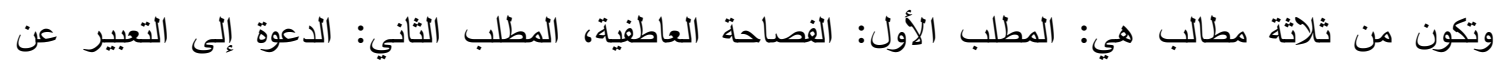

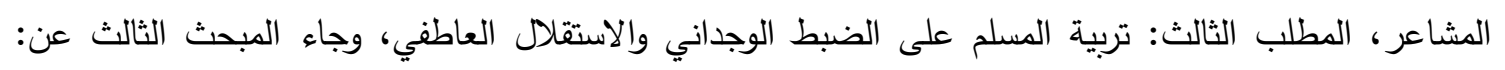

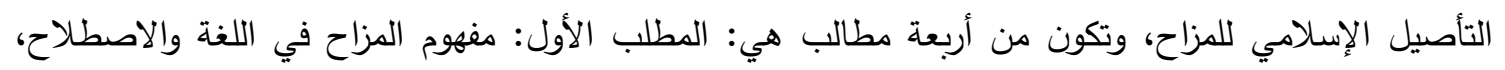

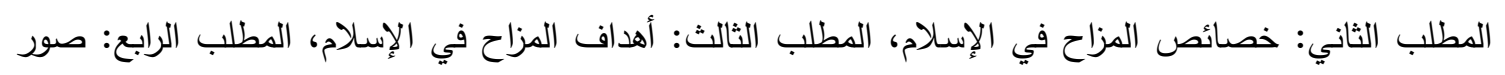

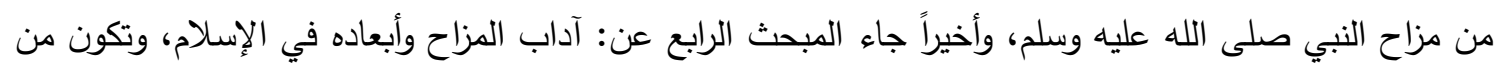

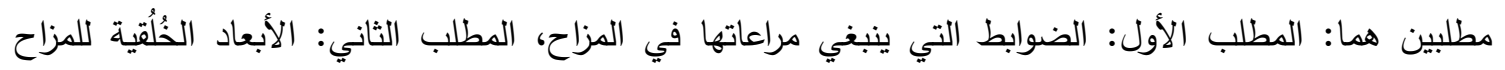

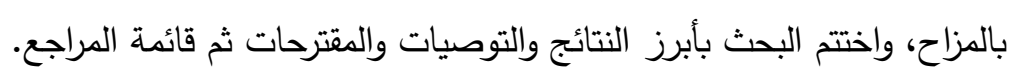
الكلمات المفتاحية: الضوابط - الآداب - التزويح - المزاح - الانفعالات.

التي يتعاملون معها، ومعرفه كيف تتصرف تلك

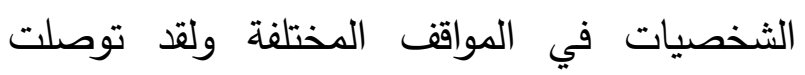
الدراسات إلى العديد من الأساليب والطرق العلمية لمعرفه هذه السمات وطباع الشخصية ومدى تكونها

\section{المقدمة}

انشغل الإنسان من قديم الأزل بمحاولات فهم ذاته ومعرفه صفات وسمات شخصيته وكما اهتم الناس الإن لتصن أيضاً بمعرفه طبيعة السمات وصفات الثخصيات ونسات 
وفي هذا السياق أوضح كل من (أنس محمد شحاتة،

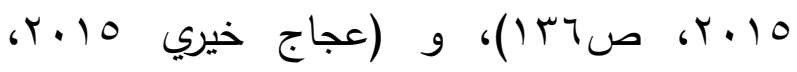
ص صاT) أن القدرات الانفعالية والاجتماعية تشكل بعداً مهماً في الأداء المعرفي وعمليات التفكير والسلوك، مما ينعكس بشكل إيجابي في تطوير قدرة الفرد على التكيف والنجاح كمًا وكيفًا، ويعد الذكاء الانفعالي من المتطلبات الضرورية لنجاح الفرد الأكاديمي، والمهني، وفي مجال العمل، والتفاعل

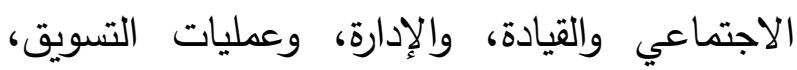
والعلاقات العامة.

ولذا من المهم التحكم في دوافع البدن في حسن توجيهها بما يتوافق مع المصلحة الفردية والجماعية،

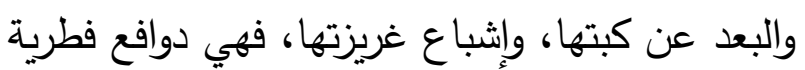
في حاجة إلى توجيا وإثباع بالحلال المسموح به شرعا، وعدم المبالغة والإسراف في إثباعها لما في

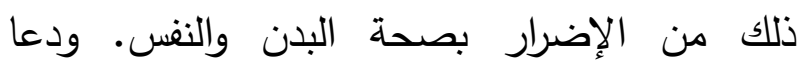
الإسلام إلى عدم الإسراف في إثباع دوافع الفطرة

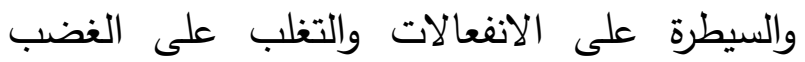
وغيره. وبينت الدراسات الطبية والنفسية الحديثة ولئي الحكمة في ذلك، إذ ثبت أن اضطراب الحياة

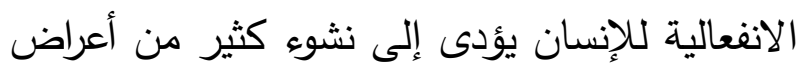

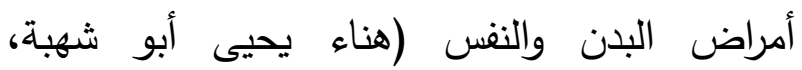

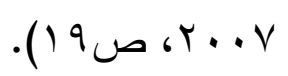
وهذا ما يتوفر فعلاً في التربية الإسلامية حيث يتميز منهجها التربوي بشموله لكافة جوانب حياة الإنسان، لئل وذلك وفق المنهج الإسلامي، حيث تهدف التربية
والتي تشكل سلوك الفرد الناتج من التفاعلات والمكونات النفسية والاجتماعية والانفعالية (فرج عبد

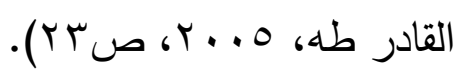
وازداد الاهتمام بدراسة الثخصية زيادة كبيرة،

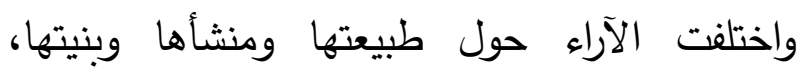
وأخذت الدراسات التي تختص بها تتثكل وتنتظم منذ

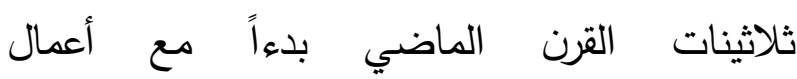
ألبورت Allportوالى ما تبعتها من دراسات وأبحاث وكتابات متخصصة متواصلة حول مجمل جوانبها. فتتاولت موضوع الشخصية نظريات التحليل النفسي هلي والنظرية السلوكية ونظرية السمات، والنظرية الإنسانية (Schultz \& Schultz, 2005, .P^) ونظريات نفسية أخرى كلٌ تبعاً منظوراتها. ويتضح الاهتمام المتزايد بدراسة الثخصية من خلال العديد من الأبحاث المنشورة في الدوريات المتخصصة. وتشير بعض الدراسات الحديثة إلى أن الإنسان

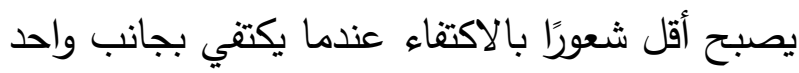
من جوانب الحياة ماديًّا كان أو رُوحيَّا، مما يؤكد بداء على أهمية وضرورة إثباع الحاجات المادية

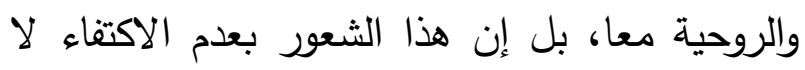

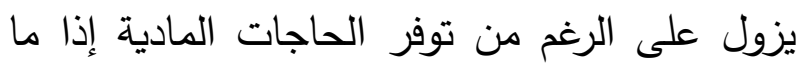
كان هناك نقص في إثباع الحاجات الرّروحية، والتي لرون يظهر أثرها لدى الإنسان فيما نسميه مظاهر الدين والأخلاق والفن، أو معايير الحق والباطل، والفضيلة

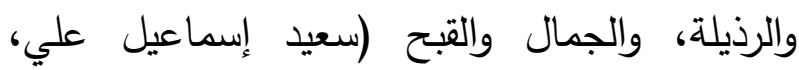
. ( VO G T... V 
وصارت روايته أغلب، ومضاحيك حديثه أكثر

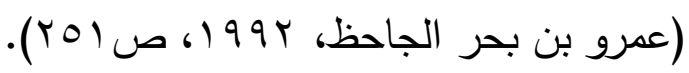

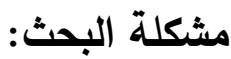

تؤثر المتغيرات والمستجدات المادية والنفعية التي تسود في ظل العولمة في شخصية وهوية الفرد وتجعله يقع في حيرة بين تمسكه بما نشأ وتربي

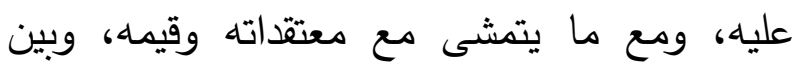

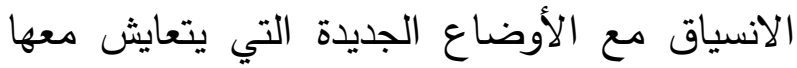
يوميا. هذا الصراع يؤدي بالثباب إلى اضطراب هويته ويفقده الإحساس بالهوية ويصبح مضطربا بوليا وجدانيا مما يؤثر على طريقة سلوكه وأفكاره، كما ساد الثباب شعورٌ متتاقضٌ وغير متكيف مع القيم

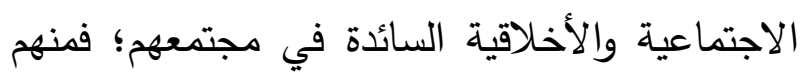
من يتجه نحو التحدي لقيم مجتمعه، ومنهم من تتعمق لديه التمايزات والفوارق ليصل إلى ممارسة مظاهر التعصب، والبعض الآخر تكرس لديه هذه المقارنة مشاعر الضعف والهزيمة النفسية وعدم الثقة

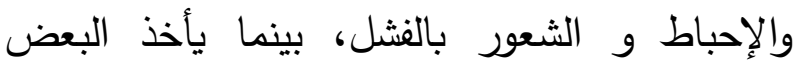

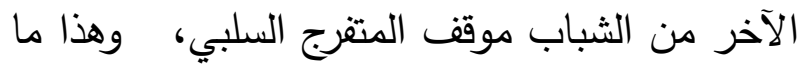
أكدته نتائج العديد من الدراسات مثل دراسة (محمود

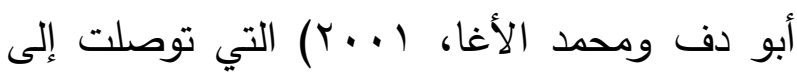
أن أهم المشكلات التي تواجه الشباب في الوقت الحاضر ، التتاقض بين القيم والمجتمع، وافتقاد الهوية

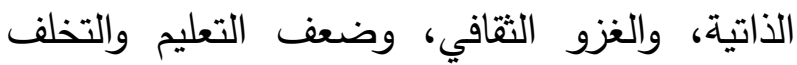

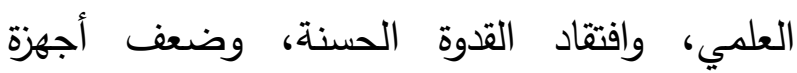
الإعلام المحلية في توجيه الشباب.
الإسلامية إلى "تربية الإنسان لحياة أخلاقية واجتماعية قائمة على أساس العقيدة الإسلامية ونظرتها الثمولية للحياة، ويتمثل الغرض الأسمى لإنى من التربية في "تهذيب الخلق، وتأديب النفس، وتربية الروح، إلى جانب الاهتمام بتثقيف العقل، وتقوية

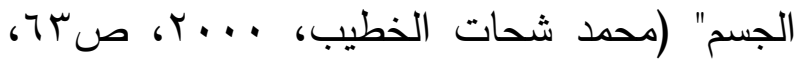
§ آ). ويعد المزاح من الجوانب التي تؤثر في شخصية الفرد وفي تعامله مع الآخرين، كما أن لهما مردود إيجابي على جوانب النمو المختلفة خاصة النفسية إذا تم توظيفهما بصورة سليمة. ولقد كانت الثقافة الإسلامية أكثر الثقافات ولَعَا بالمزاح، حتى ظهر فيها على مرِّ العصور في صور مختلفة، وعبرت عنه بمفردات متنوعة، مثل 》الهزل والمراح والبطالة والفكاهة والدعابةه، وهي مفردات تجريها المعاجم على الترادف رغم بعض الفوارق التي يشير إليها الأصل اللغوي، وكلها تعني أخذ الخدافي الأمور من جانبها الميسور العابث (حمادي صمود، لاصدي، (VT) ولم يترك المزاح مجالاً من مجالات الثقافة الإسلامية إلا دخله، فهو موجود في الثعر والنثر والمقامة، ولا

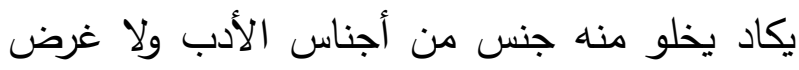

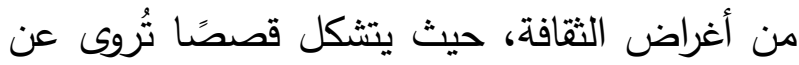
البخلاء، ونوادر في الحمقى والمغفلين، وأخبارًا في لرولي

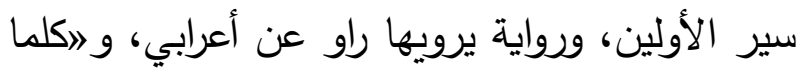

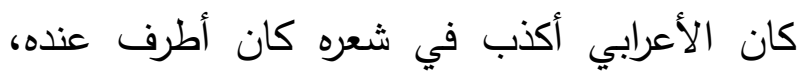


1. الآثار الإيجابية التي يمكن أن تترتب على المعال المزاح حال الالتزام بالضوابط الثرعية التي حددها لإنا

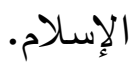
r. كثرة المزاح في الوقت المعاصر وتعدد البرامج الدقدمة فيه مما يتطلب وضع ضوابط وآداب لهذه الئ

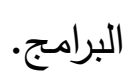
r. كثرة التحديات والمتغيرات التي تستهدف التأثير على قيم المجتمع خاصة الشباب ومن بينها المزاح.

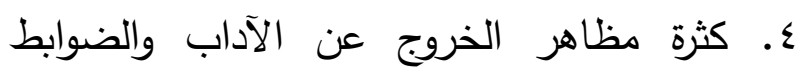
الثرعية في المزاح حتى أصبح كثيراً منه يشتمل الخدراب على ترويع الآخرين أو التعريض بهم والإنساءة إليهم.

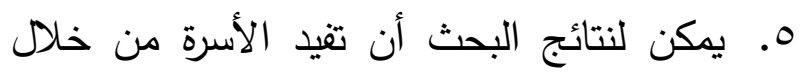
تعريفها بآداب وضوابط المزاح التي ينبغي تنتئة التئة الأبناء عليها. آ. يمكن لنتائج البحث أن تفيد المؤسسات التعليمية

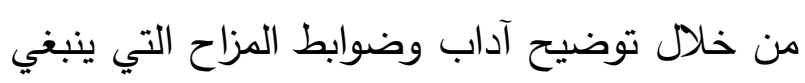
مراعاتها في الوسط التعليمي وغرسها في نفوس التساب

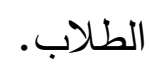

$$
\text { منهج البحث: }
$$

استخدمت في البحث الدنهج الاستتباطي، وذلك البكا باستقراء آيات القرآن الكريم وأحاديث السنة النبوية واستتباط ما يتعلق منها بآداب المزاح وضوابطه. الداسات السابقة:

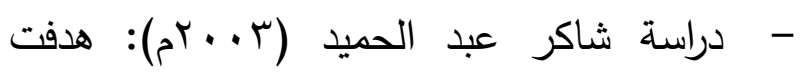
الدراسة لبحث الأهمية النفسية والاجتماعية للمزاح، من خلال دراسة المفاهيم الأساسية للضحك علداعية للمزاح،
وللميزاح وظيفة جميلة في الحياة، تأليف القلوب، تلطيف الجو، تطيبب القلوب، إدخال الفرح على قلب

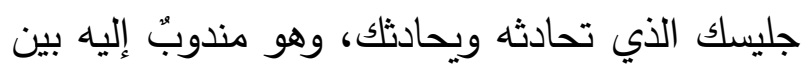

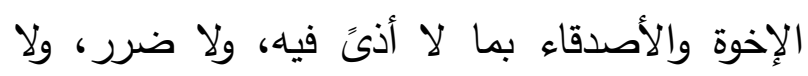

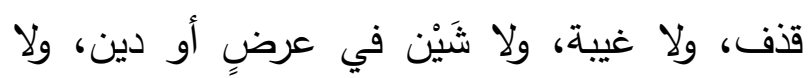
استخفافٍ بأحٍٍ منهم. امزح مع أصدقائك وإخوانك إنكا

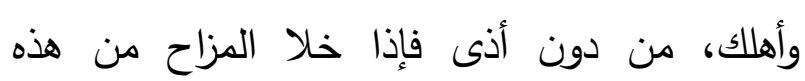
النواقص كان مزاحاً مباحاً، بل مندوباً إليه. وفي ضوء تعدد المتغيرات والتحديات التي تؤثر سلباً على قيم وثقافات الأفراد، ونظراً لشيوع كثير من النيات أنماط المزاح وصوره غير المرغوبة، كان من الأهمية تناول موضوع المزاح في الثريعة الإسلامية وبيان ضوابطه وأحكامه، وهذا ما تسعى إليه الدراسة الحالية.

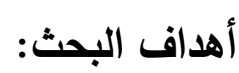
1. ما أبرز ملامح الثخصية الإنسانية وعلاقتها بالمزاح؟ r. ما منهج الإسلام في ضبط بعض المظاهر الانفعالية؟ ب. كا ما ملامح التأصيل الإسلامي للمزاح؟

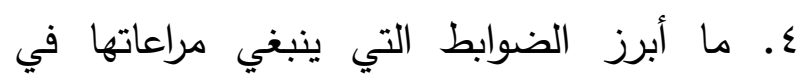

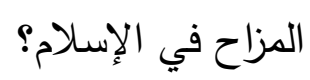
ه. ما أبرز الأبعاد الخلقية للمزاح في الإسلام.

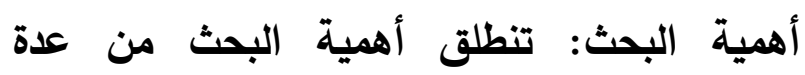
اعتبارات أبرزها ما يلي: - البعث: 
تفعيل عملية الضبط الاجتماعي بما يحقق

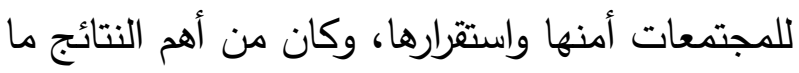
يلي: الضبط الاجتماعي في التصور الإسلامي وهو عبارة عن مجموعة القيم والمبادئ والأخلاق التي تؤمن بها جماعة ما وتستمد منها النظم والمعايير التي تضبط تصرفات الأفراد وتكفل أمن المجتمع وتحقق له الاستقرار في ضوء تطلعات المجتمع بما يحقق أهدافه المرحلية والمستقبلية، صلاح المجتمعات ونهوضها مرتبط بصلاح الأفراد فبصلاحهم تصلح المجتمعات وبفسادهم - لا قدر الله - تقسد المجتمعات، وصلاحهم منوط بصلاح تربيتهم وتعليمهم، فقل لي: أي تربية وتعليم تتلقاه؟! أقول لك: من أنت؟؛ الأساليب النبوية في التربية تقضى على مكامن الجريمة في النفس البشرية قبل

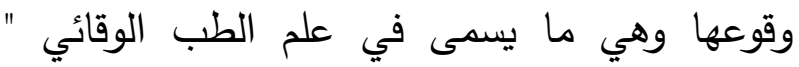
الوقاية خير من العلاج"، من خصائص الضبط الاجتماعي في الإسلام أنه ينبع من داخل النفس هن

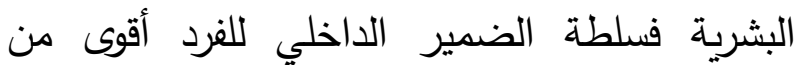
سلطة القانون الخارجي وهو ما تحققه التربية الإسلامية في عملية الضبط الاجتماعي، تعلم مبدأ أداء الحقوق والواجبات من أعظم ما تتحقق به عملية الضبط الاجتماعي متى ما أعتني وعمل بها في شتى جوانب الحياة المختلفة، تعد الأسرة من الأهمية بمكان لتفعيل أساليب النبي الاجتماعي.
الفلاسفة، ودراسة الاستجابات الفسيولوجية للضحك، وقد استخدم الباحث عدة مناهج، منها: المنهج الوصفي التحليلي، والمنهج الاستتباطي، وكان من أهم النتائج التي خلص إليها الباحث، ما يأتي:

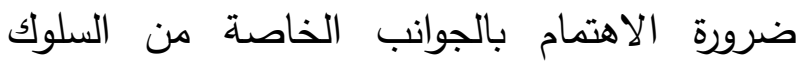
الإنساني المرتبطة بالتفاؤل والأمل، والتي منها

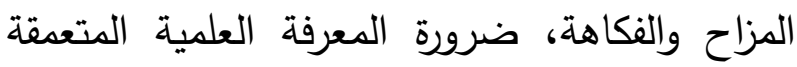
بموضوع الفكاهة والمزاح من خلال دراسة النظريات الفلسفية والسيكولوجية التي تتاولت الموضوع، أن الفكاهة والمزاح ظاهرة اجتماعية مهمة، لها علاقة وثيقة بثقافات الثعوب، بل أصبحت مرتبطة بالعولمة، حيث تستخدم في تسويق السلع، وترويج الأفكار، كما اتجهت بعض المؤسسات النفسية إلى لى العلاج بالضحك، تأكيد أن موضوع الفكاهة والمزاح

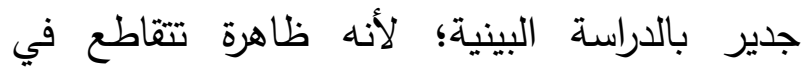
دراستها حقول معرفية عديدة، كعلم النفس، وعلم الاجتماع، والتربية، والتاريخ، والأدب، وغيرها.

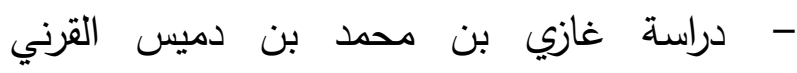

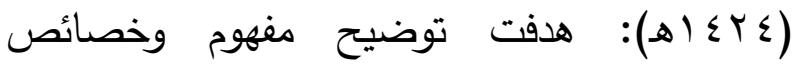
الضبط الاجتماعي في الإسلام، وإبراز دور التربية

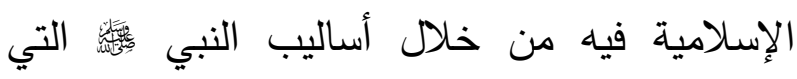
تساهم بشكل مباشر في عملية الضبط الاجتماعي، وكيفية تطبيقها في واقع الأسرة، واستخدم الباحث المنهج الوصفي لجمع المعلومات من المصادر والمراجع المرتبطة بموضوع الدراسة من إيضاح مفهوم الضبط الاجتماعي ودور أساليب النبي من في في في 
من أهداف الإرشاد والتوجيه في مدارسنا الثانوية هو توجيه الطالب إلى المنهج الرباني، يعمل التوجيه والإرشاد الطلابي على مساعدة الطالب لأداء دوره

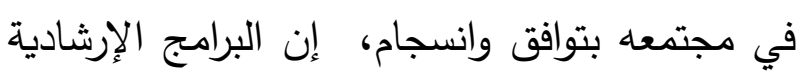
تحتل مساحة واسعة من عمل المرشد الطلابي، فهي

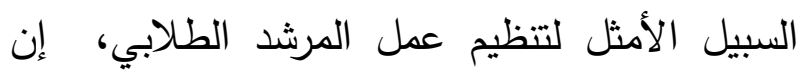
إثباع الحاجات النفسية لطلاب المرحلة الثانوية والتعامل معهم وفق مطالب النمو والتغيرات التي تمر لتصر بهم يعزز الجوانب الإيجابية عندهم، ويساهم في

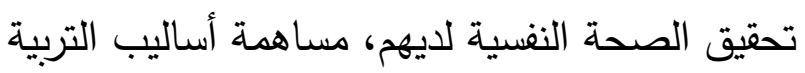

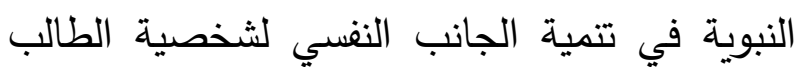
المسلم بالمرحلة الثانوية.

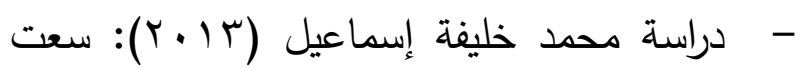
الدراسة لتقويم تأثير تدخل المعلمة باللعب مع أطفال ما قبل المدرسة على الامتثال لها داخل الروضة. وتكونت عينة الدراسة من (1) (1) طفلا وطفلة تتراوح أعمارهم من الثانية إلى الخامسة، بروضة الثنا السلام الخاصة بمدينة طنطا. وتم تدريب إحدى المعلمات

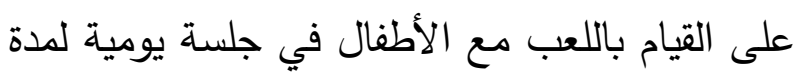

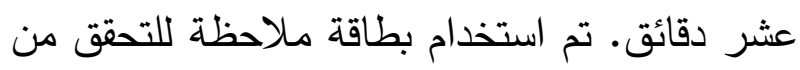
مدى تأثير التدخل باللعب على الامتثال لدى أطفال عينة الدراسة. وأشارت الملاحظات القبلية إلى تكرار صعوبات امتثال الطفل داخل قاعة الدراسة. وأشارت

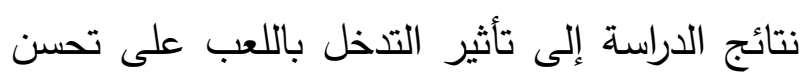

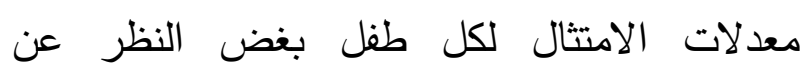

- قام (Rieger, 2004)بدراسة كيفية للكثف عن وظيفة الفكاهة لدى أسر الأطفال المعاقين،

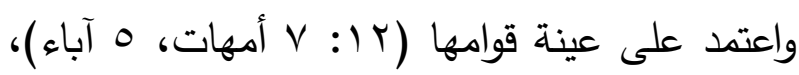
تراوحت أعمارهم بين سب: الأبناء (1) إعاقات تمثلت في (ذاتوية -توحد- ، = rا، إعاقة

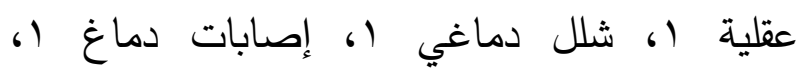

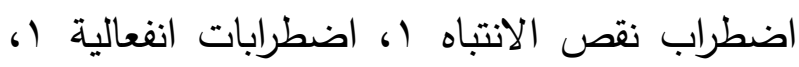
إعاقة سمعية ا، مرض فقر الدم (، إعاقات متعددة

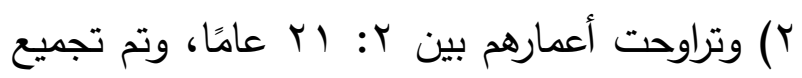

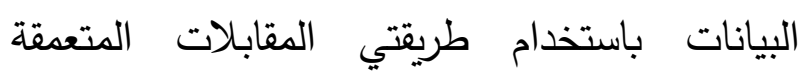
والملاحظة؛ وتوصلت النتائج إلى أن المشاركين يُدركون الفكاهة بشكلٍ يتجاوز بكثير المفهوم العام

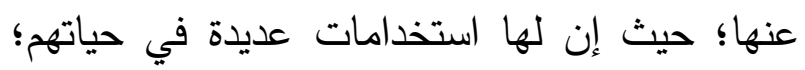
فهي تُعد وسيلة لإطلاق المشاعر السلبية والتخفف

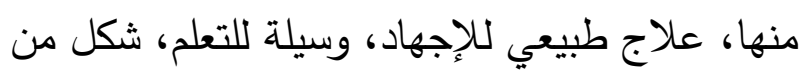
أثكال حل المشكلات، وسيلة للاتصال والتواصل، وسيلة لمنع الآخرين من الانخراط في القمع، تعبير عن الحرية، وسيلة لبناء تفكير تفاؤلي، وسيلة الخين لاكتشاف روح مرحة وهزلية في ذات الشخص.

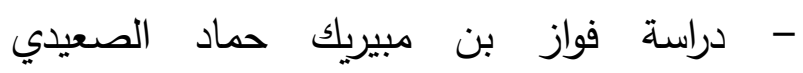

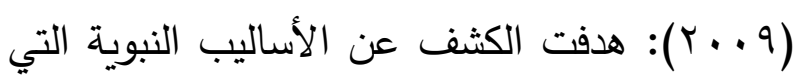

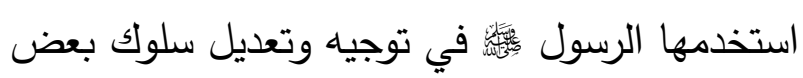

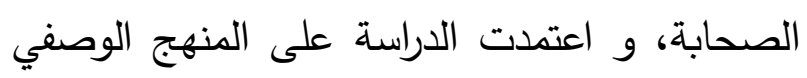

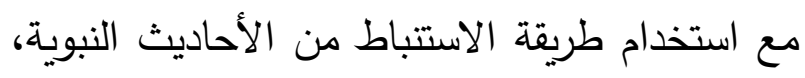

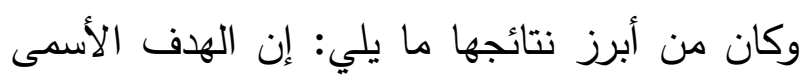


في أربعة أبعاد: عقدية، وخلقية، واجتماعية، ونفسية، اشتملت أحاديث المزاح على أبعاد عقدية عديدة، مثل: تحقيق العبودية لله وحده، وتزكية النغس وتهذيبها، والتوبة من الذنوب، والترغيب في الجنة، والدعاء، والثبات على الحق، والتذكير بنعم الله، وبلوغ كمال الإيمان، ومحبة الرسول صلى الله عليه وسلم وتوقيره،اشتملت أحاديث المزاح على أبعاد خلقية عديدة، مثل: الصبر، والصدق، والتواضع، والعفو، والحلم، والكرم، والشجاعة، والحياء، وتحقيق القدوة الحسنة، اشتملت أحاديث المزاح على أبعاد اجتماعية عديدة، مثل: العدالة، والحرية، والمساواة، والأخوة، والتعاون، والتراحم، وبذل النصيحة، وتقديم الهدية، تضمنت أحاديث المزاح أبعادا نفسية، مثل: السعادة، والرضا، والأمن، والعزيمة، والتفاؤل، والمحبة، وجهاد النفس.

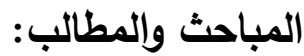

المبحث الأول: ملامح الثخصية الإنسانية وعلاقتها بالمزاح المطلب الأول: مفهوم سمات الشخصية

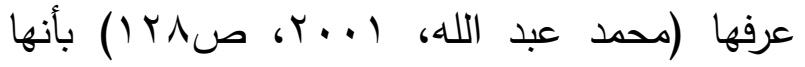
"المجموع الدينامي المنظم لخصائص الإنسان" وصفاتها المعرفية والانفعالية والجسمية والاجتماعية التي تميزه عن غيره وتحدد درجة تكيفه مع بيئتـه" والشخصية هي أكثر التصورات الذهنية موائمة لسلوك الشخص في كل تفاصيله التي يمكن للعالم
الاختلافات في العمر والجنس، ومستوى الصعوبة في الامتثال. - ملبحث ما إذا كان الحس الفكاهي كأسلوب مواجهة يتنبأ بفعالية الأسرة قام كل من \&ieger \&) بتطبيق مقياس الفكاهة MC Grail, 2013) كأسلوب للمواجهة، ومقياس تقييم تماسك وتوافق الأسرة على (VY) من أمهات الأطفال الذاتويين، الذين تتجاوز أعمارهن التسعة عشر عامًا، وانتهت النتائج إلى أن الفكاهة كأسلوب مواجهة تتبأ بشكلٍ دال بتماسك الأسرة ومرونتها.

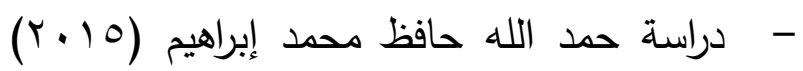
هدفت الدراسة إلى التعرف على الأبعاد التربوية للمزاح بالمزاح في ضوء السنة النبوية المطهرة، ممثلة في: الأبعاد العقائدية، والأبعاد الأخلاقية، والأبعاد الاجتماعية، والأبعاد النفسية، وقد اعتمد الباحث على المنهج الوصفي التحليلي، كما تم استخدام المنهج الأصولي الاستنباطي، ولإتمام هذه الدراسة قام الباحث بتحليل الأحاديث النبوية الدالة على المزاح بالمزاح؛ وتوصلت الدراسة إلى العديد

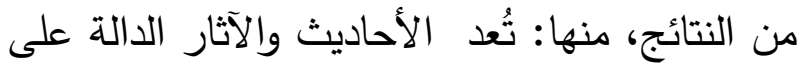
مزاحه صلى الله عليه وسلم من الأحاديث النبوية التي تتضمن الترغيب في أعمال الخير، وتردع النفس عن أعمال الشر، مشتملة على أمور الحياة العقائدية والخلقية والاجتماعية والنفسية، تضمنت هذه الأحاديث الثريفة أبعادا تربوية متعددة، لها أثر كبير في حياة المسلم، تمثلت ـ من وجهة نظر الباحث . 
• سمات ديناميكية: تهئ الفرد وتدفعه نحو

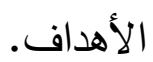

سمات قدرة: تتعلق بمدى قدرة الفرد على تحقيق

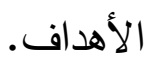

المطلب الثاني: مكونات الثخصية: يولا الإنسان كوحدة بيولوجية تتفاعل مع وحدة أكبر هي وحدة البيئة المادية والاجتماعية، ويستمر هذا التفاعل مادام الإنسان على قيد الحياة، حيث تتشكل الشخصية وتنمو وتتحدد معالمها وبصمتها وتصبح تتظيم دينامي داخل الفرد، ينظم الأجهزة النفسية والجسمية التي تفرض على الفرد طابعا خاصا في السلوك والتفكير، أي أنها جملة السمات الجسمية والعقلية والانفعالية والاجتماعية الموروثة والمكتسبة والتي يتميز كل شخص عن غيره، وإن صح التعبير فهي تركيبة من عدة مكونات، يمكن تحليلها إلى:

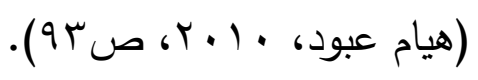

أ. المكونات الجسمية: تتعلق بالثكل العام للفرد وصحته من الناحية الجسمية، مثل اللون، الطول، الوزن، الصحة العامة، الأداء الحركي، ألأمراض الجسمية، والإعاقات ووظائف الحواس وأجهزة الجسم المختلفة، العصبي، الدوري، الغدد. إلخ. ب. المكونات العقلية المعرفية: ونقصد بها وظائف العقل العليا كالذكاء العام والقدرة الخاصة كالقدرة العددية واللغوية والميكانيكية والفنية وكذلك العمليات النفسية كالانتباه والتنكر والإدراك.
تقديمها في لحظة ما من الوقت (حلمي المليجي،

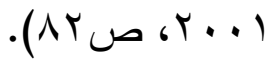

وتعرف السمة بأنها هي وحدة بناء الشخصية، وهي عامل أو متغير (Factor)، أي أنها تجمع من العوامل المرتبطة فيما بينها ولها مصادر مشتركة .(Block, 2001, 102)

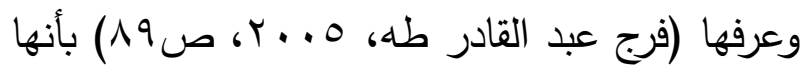
ميل أو نزعة مستقرة ثابتة نسبياً لدى الفرد والاتساق في سلوك الفرد الانفعالي والمزاجي والاجتماعي في مختلف المواقف، وهي صفة تعبر عن الاختلاف بين الأفراد في سلوكهم، فالسمة تعتبر تكوينا فرضياً يمكن استتتاجه، وثباتها يسمح بدرجة من التنبؤ بالسلوك. وقد صنفت السمات بصورة عامة كما يلي: (ختام عبد الله. غنام، 0 . . r6، ص وr). سمات فريدة: لا تتوافر إلا في أفراد معينين، ولا توجد على نفس الصورة بالضبط لدى الآخرين. • سمات مشتركة: يتسم بها مجموعه كبيرة من

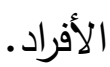
• سمات سطحية: وهي السمات الواضحة الظاهرة. • سمات مصدرية: وهي السمات الكامنة غير الظاهرة. - ما سمات مكتسبة: تتتج عن فعل العوامل البيئية وهي سمات متعلمة. سمات وراثية: وهي سمات تكوينية تتتج عن

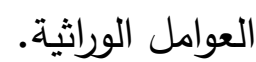


Personality Compass ويتميز كل نمط بصفات خاصة يقل وجودها في الأنماط الأخرى وهذه الأنماط هي: طبيعة الشمالوطبيعة الجنوب- وطبيعة الشرق- وطبيعة الغرب. وتؤكدان بأن لاى كل فرد بعض المميزات من كل وطل أنماط الطبيعة الأربعة، لكن إحدى الطبائع تكون طاغية على جوهر الشخصية أكثر من البقية .(Turner \& Greco, 1998, P19)

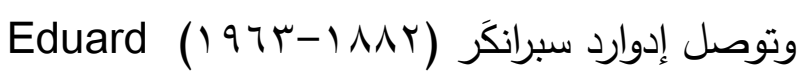
Spranger الشخصيات وملاحظته لسلوك الأفراد، إلى تصنيف

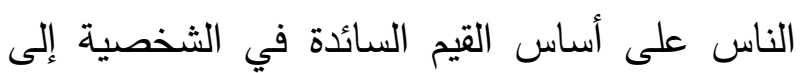

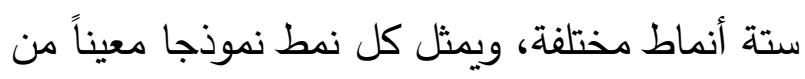
الشخصية وهذه الأنماط هي: النمط النظري- والنمط

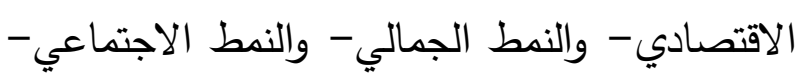

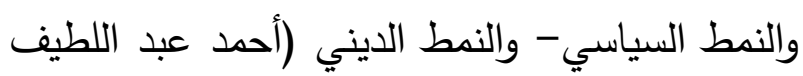

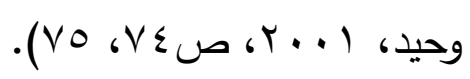

ثانياً: العوامل الخمسة الكبرى للشخصية:

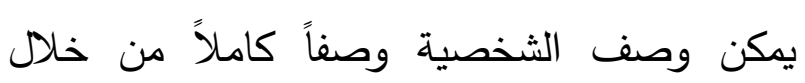
خمسة عوامل أساسية هي:

ا. العصابية: Neuroticism (N) إلى الأفكار والمشاعر السلبية أو الحزينة، فالدرجة المرتفعة تدل على أن الأفراد الذين يتميزون

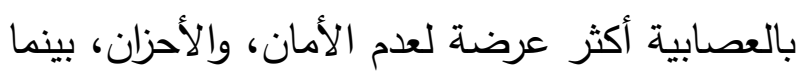
تدل الدرجة المنخفضة على أن الأفراد الذين يتميزون الأنان

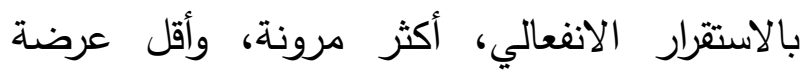

ج. المكونات الاجتماعية: ويقصد بها قدرة الفرد على تكوين علاقات مع كثير من ألأفراد أو تكوين علاقات مع جماعات. د. المكونات الانفعالية: وتتعلق بالنشاط الانفعالي

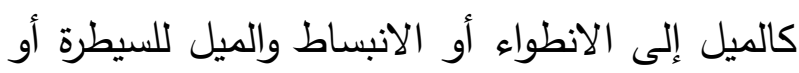

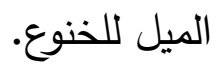
هـ. المكونات البيئية: تتعلق بالعواطف والاتجاهات والقيم التي تكتسب من البيئة التي يعيشها الفرد كالأسرة والمدرسة والمجتمع. هذه المكونات تتحدد بتفاعل العوامل الفسيولوجية والبيئية ولا شك أن التغير الذي يحدث لأحد هذه المكونات نتيجة العوامل الفسيولوجية والاجتماعية يؤثر بدوره في تكوين الثخصية مما يؤكد عملية تفاعل تلك المكونات وتأثيرها ببعضها مما يؤكد بدوره فكرة التكافل الديناميكية بينها. المطلب الثالث: أنماط الثخصية وعواملها الخمسة أولاً: أنماط الثخصية: يقسم يونك الإنسان إلى نمطين رئيسيين الشخصية

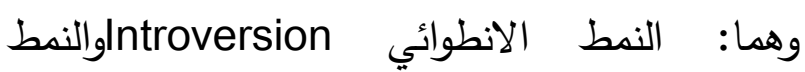
الانبساطي:Extroversion. فالإنسان المنطوي هو الإنسان غير الاجتماعي الذي يميل إلى الانعزال والانفراد. والإنسان المنبسط يرغب في الاختلاط الإنس لإنيان ومعاشرة الآخرين (Crow, 1968, P. 164). أما تورنر وكريكو Turner \& Greco فاعتقدت الاختين بتصنيف شخصية الإنسان حسب التقسيم الثقافي الجغرافي للبشر وأطلقتا على ذلك "بوصلة الثخصية 
ع. المقبولية: Agreeableness (A) يعكس هذا العامل كيفية التقاعل مع الآخرين، فالدرجة المرتقعة

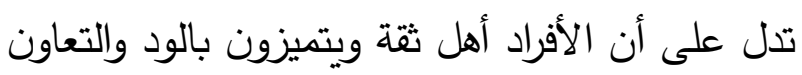

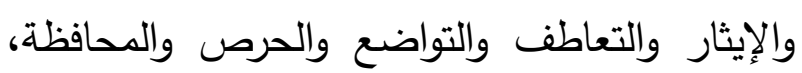

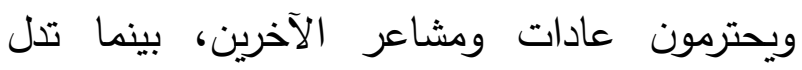
الدرجة المنخفضة على العدوانية وعدم التعاون،

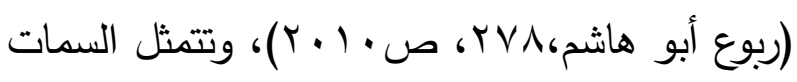

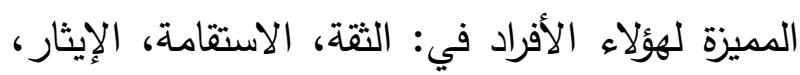

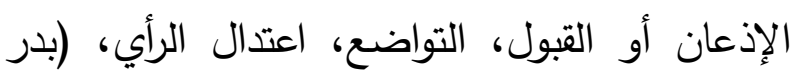

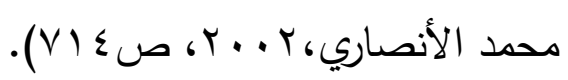

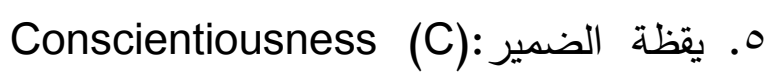
وتشمل المثابرة والتنظيم لتحقيق الأهداف المرجوة، فالدرجة المرتفعة تدل على أن الفرد منظم، ويؤدي التفي

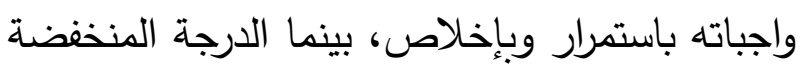

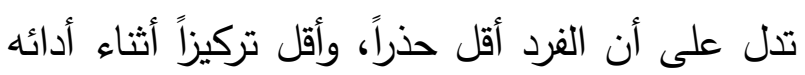

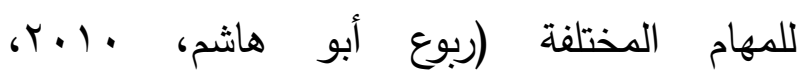

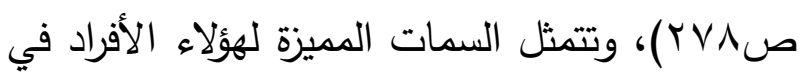

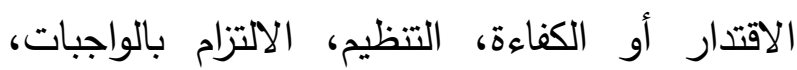

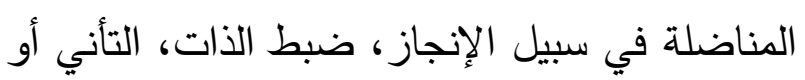

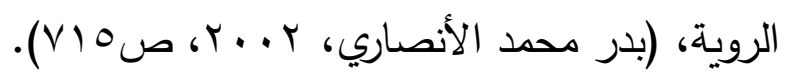
المبحث الثاني: ضبط بعض المظاهر الانفعالية في الإسسلام

المطلب الأول: الفصاحة العاطفية:

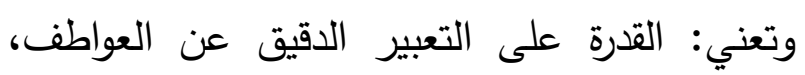
والقدرة على التعبير عن الحاجات المرافقة لهذه العواطف (مأمون المبيض، د.ت، صسب (1).

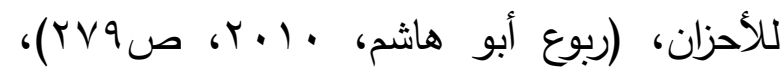

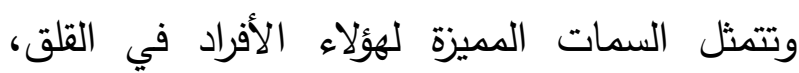
الغضب، العدائية، الاكتئاب، الانعصاب والقابلية

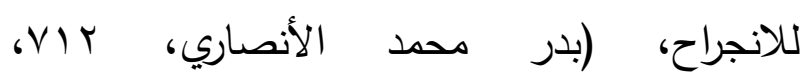

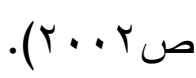
r. Extraversion (E) التضضيل للمواقف الاجتماعية والتعامل معها، والاستقلال والتفتح الذهني، فالدرجة المرتفعة تدل على أن الأفراد مرتفعي الانبساطية يكونوا نشطين

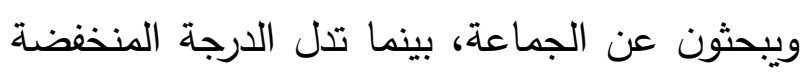

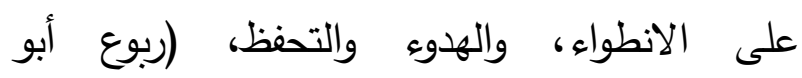

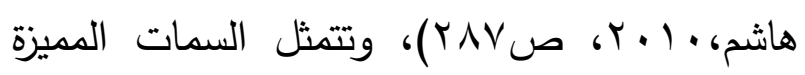

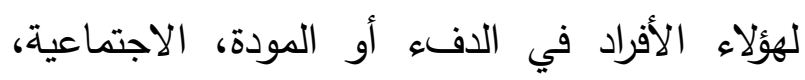

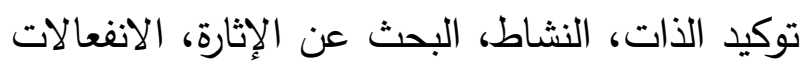

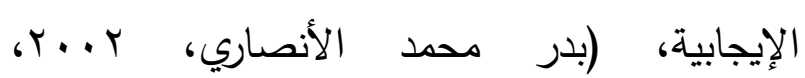
ص (V) - (v).

ب. الانفتاحية على الخبرة: Openness to experience (O) بالثقافة، والتفوق وحب الاستطلاع، وسرعة البديهة،

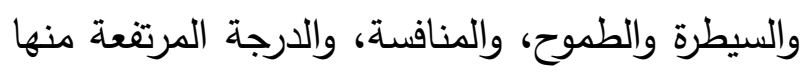
تدل على أن الأفراد خياليون، ابتكاريون، ويبحثون ولني

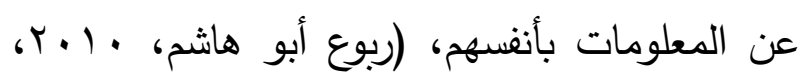

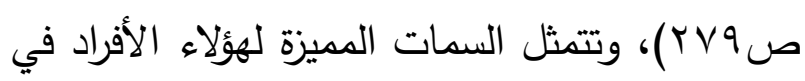

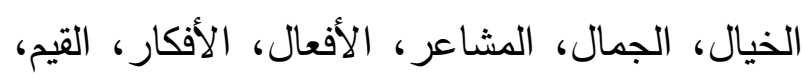

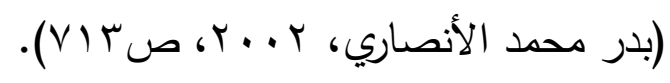




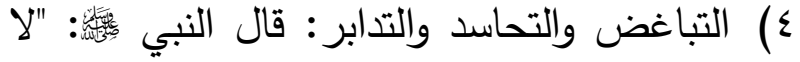
تباغضوا ولا تحاسدوا ولا تدابروا وكونوا عباد الله إخواناً، ولا يحل لمسلم أن يهجر أخاه فوق ثلاثة أيام"(محمد بن إسماعيل البخاري، ل•• إه، رقم .$(7.70$

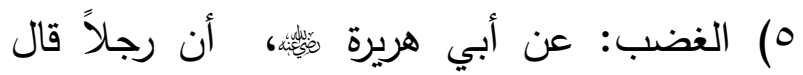
للنبي "إس قال: "لا تغضب"(محمد بن إسماعيل البخاري،

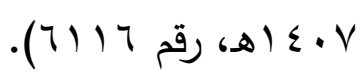

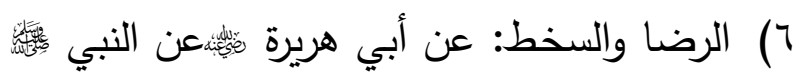

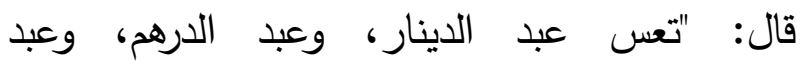
الخميصة، إن أعطي رضي وإن لم يعط سخط..."

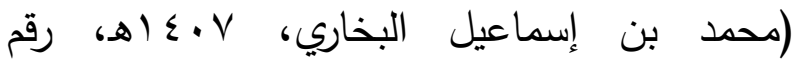
. ( YAN V الحزن والهم: عن عائشة رضي الله عنها قالت: قال رسول الله ولا نصب ولا سقم ولا حزن حتى الهم يهمه إلا كفر

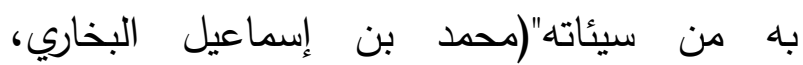

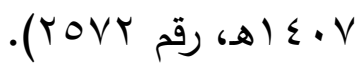

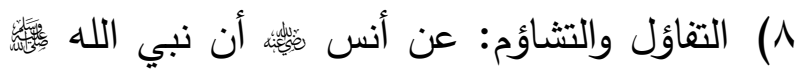
قال: "لا عدوى ولا طيرة، ويعجبني الفأل: الكلمة

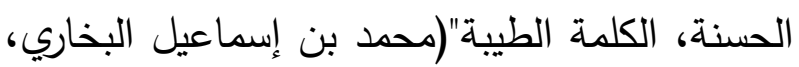

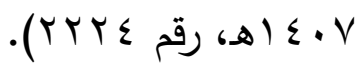

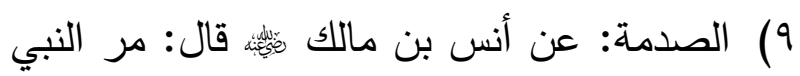

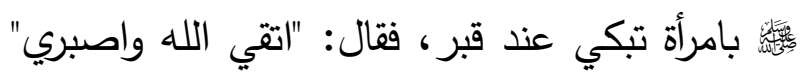
قالت: إليك عني فإنك لم تصب بندي بصيتي ولم
والمتتبع للسنة النبوية يلحظ الاستعمال النبوي الدقيق

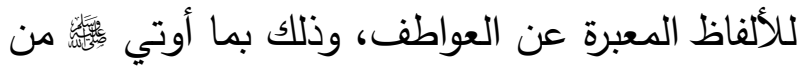
جوامع الكلم، ومن دقة التعابير النبوية في هذا المجال وصف شدة هذه الانفعالات وسهولتها. ومع غزار الألفاظ النبوية في وصف العدة العواطف الإنسانية يمكن جمع معجم عاطفي في السنة النبوية، لذلك سأذكر أهم الانفعالات والعواطف التي هدجي ورد ذكرها في السنة النبوية، مكتفياً بذكر دليلٍ واحدٍ على كلٍ منها اختصاراً.

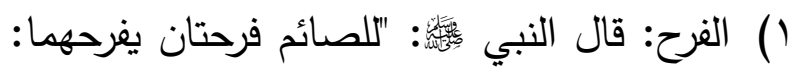
إذا أفطر فرح، وإذا لقي ربه فرح بصومه" (محمد بن

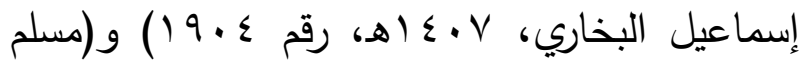

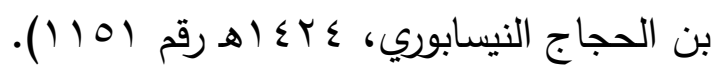
r الحب والكراهية: فعن ابن عباس رضي الله عنهما أن زوج بريرة عبد أسود يقال له مغيث، كأني أنظر إليه يطوف خلفها ييكي ودموعه تسيل على لحيته، فقال النبي من حب مغيث بريرة، ومن بغض بريرة مغيثاً..."

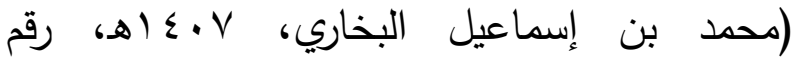
. OrNT r) التعاطف والتواد والتراحم: قال النبي "ن المؤمنين في تراحمهم وتوادهم وتعاطفهم كمثل الجسد، إذا اشتكى عضواً، تداعى له سائر جسده بالسهر

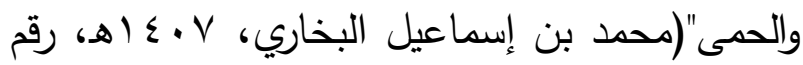
.$(7.1)$ 
المطلب الثاني: الدعوة إلى التعبير عن المشاعر: فقد كان النبي

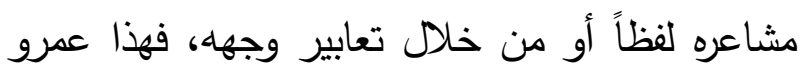
بن العاص يسأله: أي الناس أحب إليك؟! فلا يتردد النبي دي الصحابي سؤاله عن مشاعره، فيقول: "عائشة..."

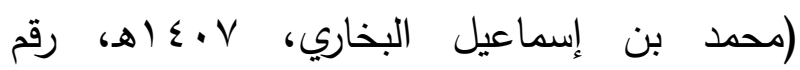

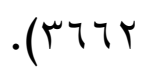

وهذه عائشة رضي الله عنها تسأله عن أثد يومٍ أتى عليه، فتقول: هل أتى عليك يوم كان أشد من يوم أحد؟ فيجيبها عن همومه ويبث لها حزنه قائلاً: "لقد لقيت من قومك ما لقيت، وكان أشد ما لقيت منهم يوم العقبة، إذ عرضت نفسي على عبد ياليل بن عبد كلا، فلم يجبني إلى ما أردت فانطلقت وأنا مهموم

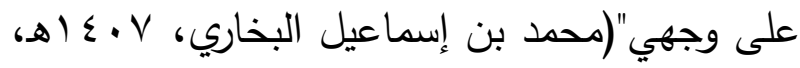
رقم اسبץ) و و(مسلم بن الحجاج النيسابوري،

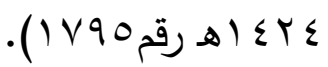

وكان النبي

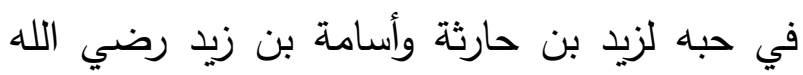

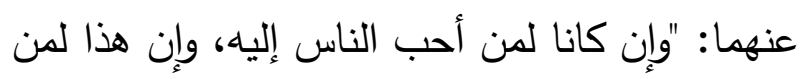

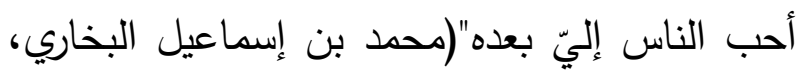

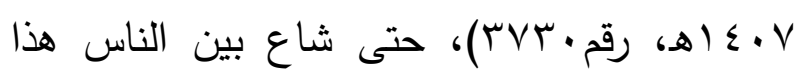

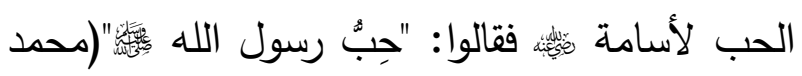

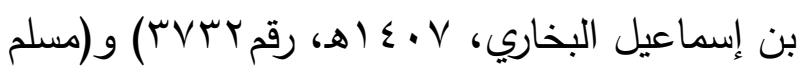

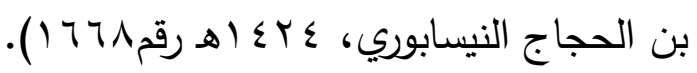

تعرفه. فقيل لها: إنه النبي

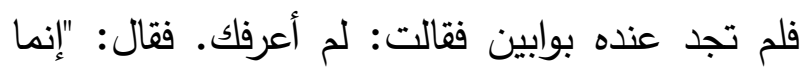
الصبر عند الصدمة الأولى"(محمد بن إسماعيل

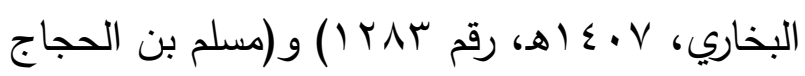

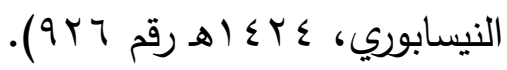

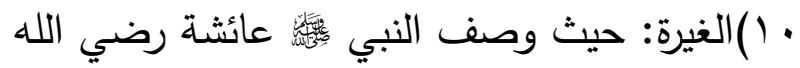
عنها بذلك فقال: "غارت أمكم"(محمد بن إسماعيل

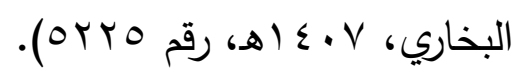
هذه بعض العواطف والانفعالات الإنسانية التي أوردتها

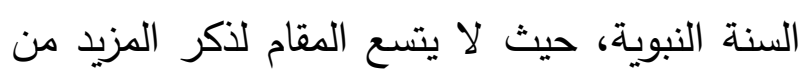

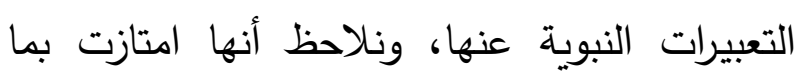
يأتي:

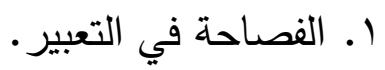
r. الدقة في الوصف.

r. التتوع في التعبير : فالبغض يعبر عنه النبي

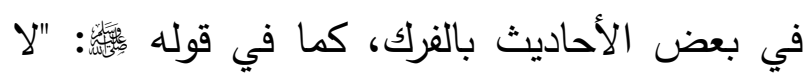
يفرك مؤمن مؤمنة، إن كره منها خلقاً رضي منها لاحها

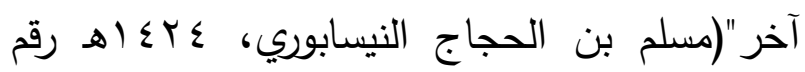
.$(1 \leq 79$ ع. شمولها لمجمل العواطف الإنسانية. 0. استعمال التضاد في بيانها زيادة في الوضوح

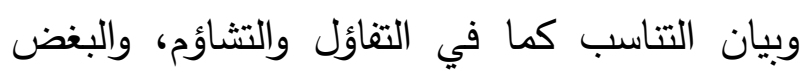
والحب. T. الربط بين عدد من العواطف لما بينها من أثر،

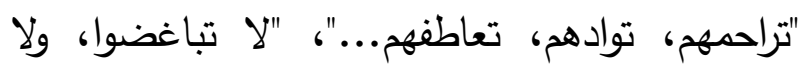
تحاسدوا، ولا تحاسدوا، ولا تدابروا...". 
وكانت مشاعره :

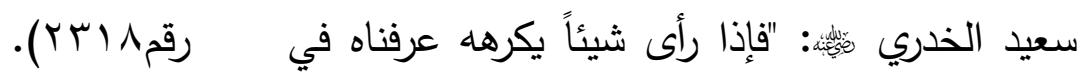

وعندما تعجب عبد الرحمن بن عوف خوفئ山 من حزن

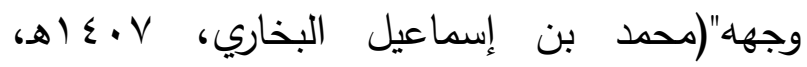

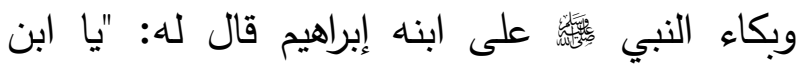

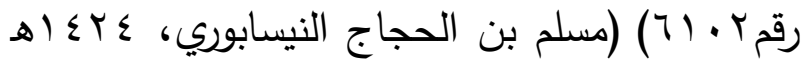
عوف إنها رحمة..." (محمد بن إسماعيل البخاري،

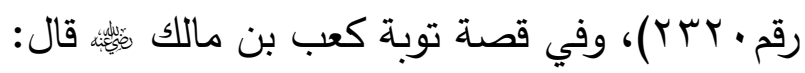

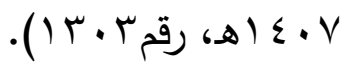
المطلب الثالث: تربية المسلم على الضبط الوجداني والاستقلال العاطفي: لعل من المسلم به لدى التربويين أن التربية أصبحت تهدف إلى إعداد الشخصية المتكاملة جسميًا وعقليًا ونفسيًا واجتماعيًا، وأن من أهم واجباتها - من الهن

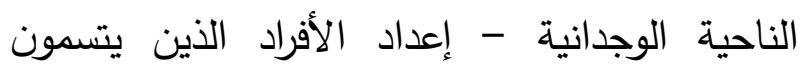
"فلما سلمت على رسول الله : من السرور، ويقول: "أبشر بخير يوم مرّ عليك منذ

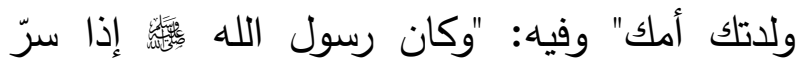
استتار وجهه كأنه قطعة قمر، قال: وكنا نعرف

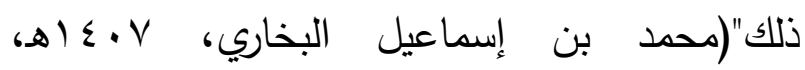

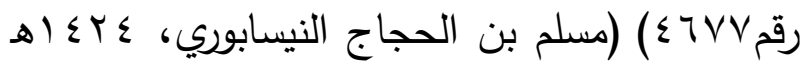
بالاتزان الوجداني والثقة بالنفس. وتحرص التربية الوجدانية في الإسلام على أن بلن فئن تستهدف في تربية المسلم ما قد يسمى بالنضج الوجداني كدلالة على نضج الشخصية. فالمؤمن لئن ليس متبلد الوجدان ولا بارد العاطفة، قال تعالى: \}ويخرون للأذقان يبكون ويزيدهم خشوعائ (سورة الإسراء، الآية: 9 • (1)، وعن النبي صلى الله عليه وسلم: "والذي نفسي بيده لا تدخلوا الجنة حتى الإهى تؤمنوا، ولا تؤمنوا حتى تحابوا" (يحيى بن شرف لهن النووي، 910 (، ص (1) ). وليس من سماته الانفجار

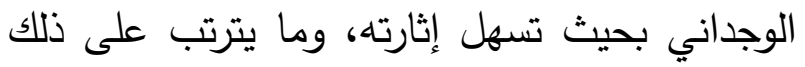
من عنف ورعونة، إنما هو قوي التحمل يتميز بالهدوء والثبات والتحكم الوجداني مما يجعله لا يندفع

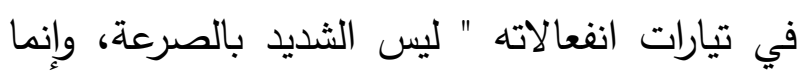

وحث النبي

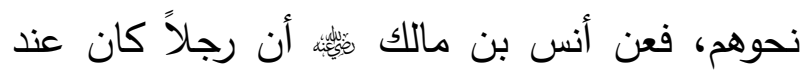
النبي

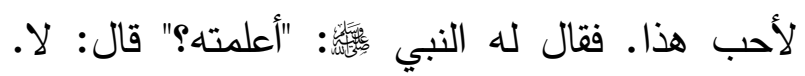
قال: "أعلمه" قال: فلحقه فقال: إني أحبك في الله. فقال: أحبك الذي أحبيتني له (أبو داود سليمان بن إن إن الأشعث، 1991، رقم الشيباني، د.ت، رقم • ـ ( ).

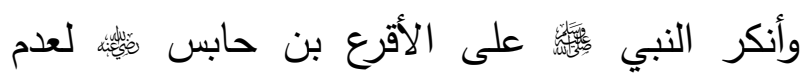
إظهاره لحب أبنائه بتقبيلهم، فهذا الأقرع يبصر النبي لني

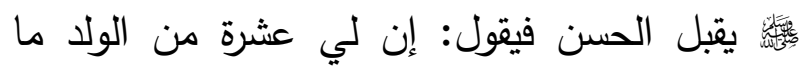
قبلت واحداً منهم. فقال الرسول فئس

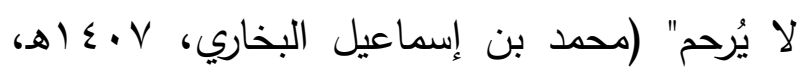


وفي حديث النبي صلى الله عليه وسلم: " لا تكونوا إمعة تقولون إن أحسن الناس أحسنا، وإن ظلمان إنها: ظلمنا، ولكن وطنوا أنفسكم إن أحسن الناس أن تحسنوا، وإن أساءوا فلا تظلموا " (عبد الرحمن بن الرنان

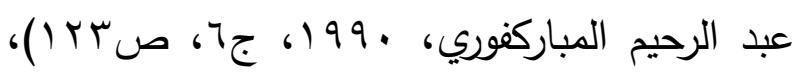
ومما ينبغي أن يتسم به المسلم عدم التأثر الوجداني

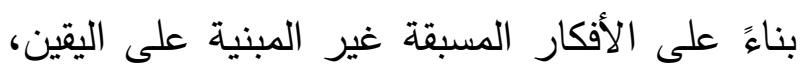
سواءً كانت عن الأشخاص أو التصورات أو غيرها،

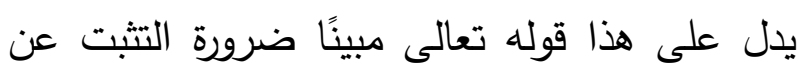
سماع نبأ الفاسق قبل صدور أية ردود أفعال غير محمودة يترتب عليها آثار وجدانية مؤلمة: ريا أيها الذين آمنوا إن جاءكم فاسق بنبإ فتبينوا أن تصييوا قوما بجهالة فتصبحوا على ما فعلتم نادمين) (سورة

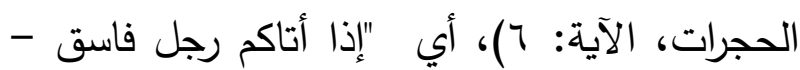
غير موثوق بصدقه وعدالته - يخبر من الأخبار . . فتبينوا من صحة الخبر. لئلا تصيبوا قوما وأنتت جاهلون حقيقة الأمر .. فتصبحوا نادمين أشد الندم

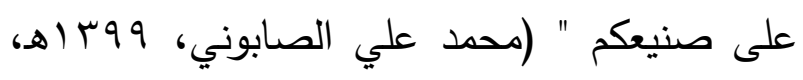

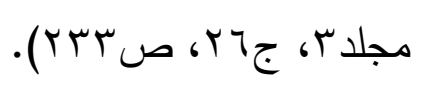
والمؤمن إنسان من خلقه الخشوع والتواضع والتسامح والمودة، وغير ذلك من قيم واتجاهات موجبة من شأنها تأليف القلوب وقد مدح الله تعالى رسوله وله بلين الجانب مع المؤمنين لما له من أثر طيب في تعاليب

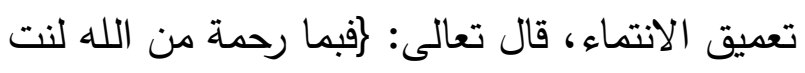

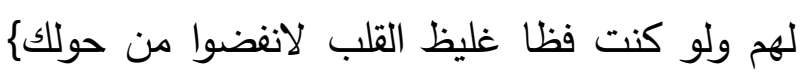
(سورة آل عمران: آية 109)، على أن تواضع
الثديد الذي يملك نفسه عند الغضب"(يحيى بن

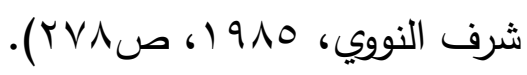
وإذا كان الغيظ - على ما ذكر الثيخ محمد عبده

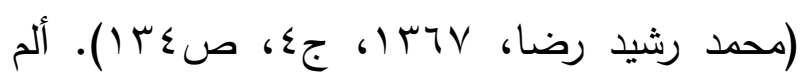
يعرض للنفس إذا هضم حق من حقوقها المادية أو

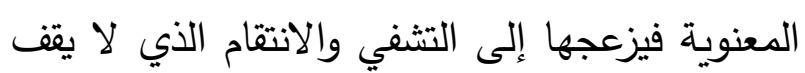
عند حد الاعتدال. فإن الله قد أثنى على الكاظمين

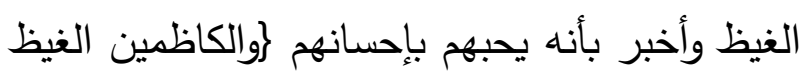
والعافين عن الناس والله يحب المحسنين) (سورة آل باله

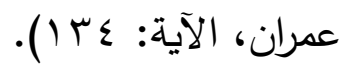
إن الإنسان عندما يكون رابط الجأش في مواقف الإنف الثدة، يقلب وجوه الرأي ابتغاء مخرج مما عراه، فإن إن

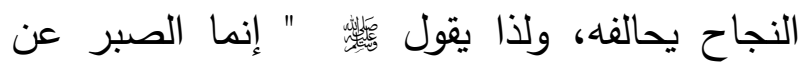

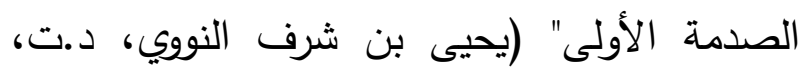

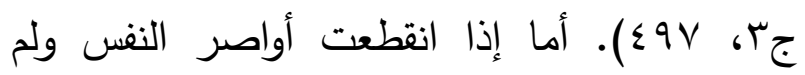
يربطها نظام يركز قواها، فعندئذ تنفرط مكوناتها الوجدانية والعقلية وتصبح لا خير فيها كالذي قال الله تعالى في وصفه: (أغفلنا قلبه عن ذكرنا واتبع

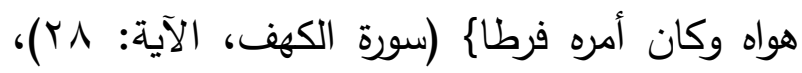
مما يدل على ضرورة العمل الدائم لتتظيم الوجدان حتى يعود إليه الضبط والاعتدال، وذلك كلما هزته

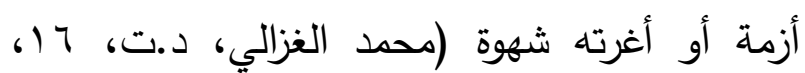
.$(1 \mathrm{~V}$ والإسلام يربى المسلم على الاستقلال العاطفي وعدم الانسياق وراء الآخرين في مواقفهم وعواطفهم، الأمر الإنيا الذي يؤدي إلى انمحاء الثخصية وفقدان هويتها، 
فالجذور اللغوية للكلمة تشير إلى معاني الانبساط والسرور والخروج من الثقل، وهو قريب من المعنى الهی الاصطلاحي للمزاح.

وفي الاصطلاح: المباسطة إلى الغير على جهة

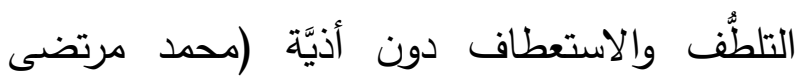

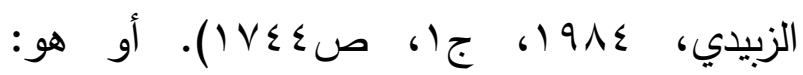
مباسطة لا تؤذي المخاطَب ولا توجب حقارته، بخلاف الهزل والسخرية، أي: الاستهزاء (عبد النبي

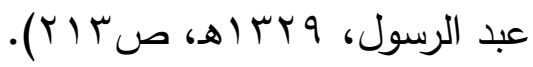
وهو كل نشاط حركيّ أو قوليٍّ، يقدم عليه الفرد أو أو الجماعة بهدف مداعبة الغير، والمزاح عن الذات، لهني لتحقيق التجانس النفسي والتوافق المزاجي، سواء

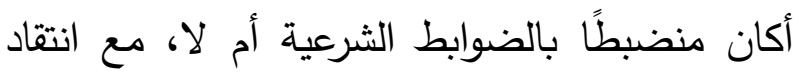

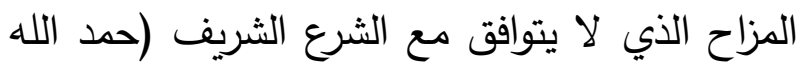

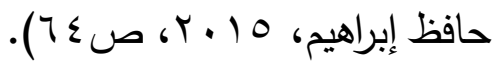
المطلب الثاني: خصائص المزاح في الإسلام.

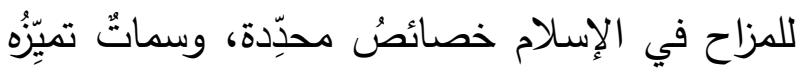
عن غيره من ألوان النشاطات البشرية، والممارسات الإنسانية التي يُقصَد بها المزاح، ومن خلال دراستنا

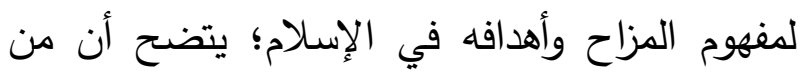
أهمّ خصائصسه:

ا. الإفادة والمردود الإيجابي: فالمزاح في الإسلام ليس مجرد مله لوقت الفراغ، بل هو نشاط هادف لهاف وبنَّاء، يساهم في تطوير شخصية الفرد، من خلال

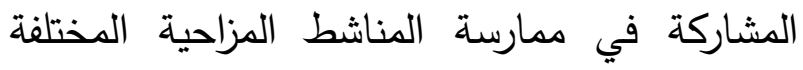
(محمد الحماحمي، وعايدة عبد العزيز،
المؤمن ولينه لا ينبني أن يؤدي به إلى الضعة

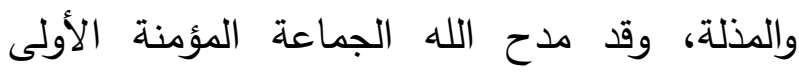
بالثدة على الكفار والرحمة بالمؤمنين، قال تعالى: محمد رسول الله والذين معه أثداء على الكفار رحماء بينهم. .... (سورة الفتح: آية). المبحث الثالث: التأصيل الإسلامي للمزاح المطلب الأول: مفهوم المزاح في اللغة والاصطلاح (المزاح) في اللغة: نقيض الجد. ومَزَحَ يَمْزَحُ مَزَحًا

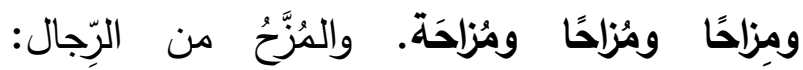

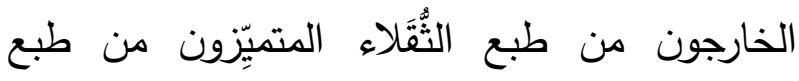
البُغَضَاء (محمد بن مكرم بن منظور، د.ت، جَّاء

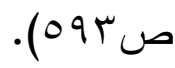
قال في المختار الصِحِحاحه: المَزْحُ: الدعابة، وبابه

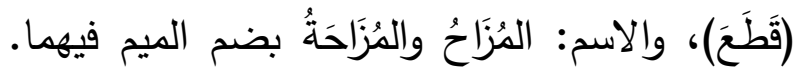

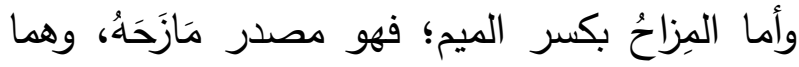

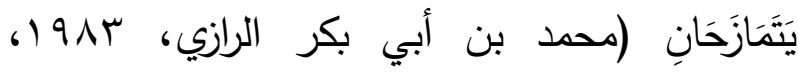

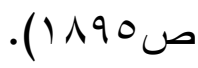

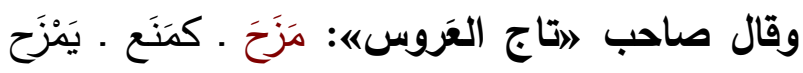

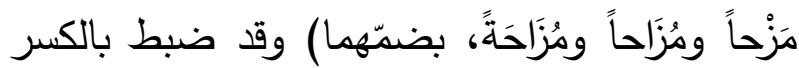

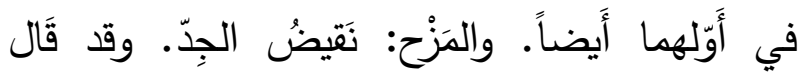

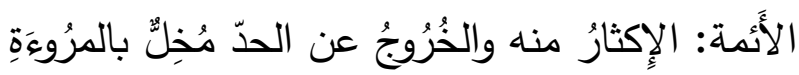

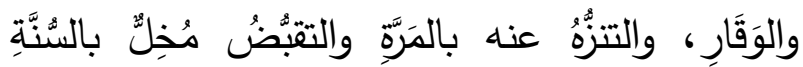

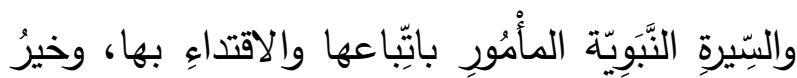

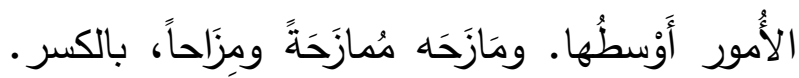

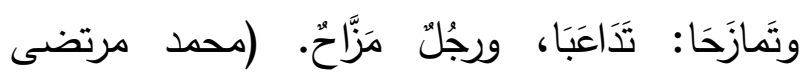

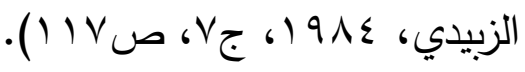


تضييعًا للوقت بلا فائدة (عبد الله ناصر السدحان،

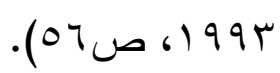
7. الاختيارية: حيث يختار الفرد نشاطه المزاحي وفقًا لرغبته ودوافعه، ولا يعني هذا إغفال التوجيه التربوي نحو إرشاد الفرد لممارسة نوع من النشاط يتفق وميوله ودوافعه وحاجاته واستعداداته وقدراته ومستوى نضجه (محمد الحماحمي، وعايدة عبد العزيز ، 0 . 9 (، صع ع).

V. تحقيق التوازن النفسي: وذلك من خلال إثباع الفرد الممارس للمزاح لحاجاته النفسية، كما أن المشاركة في مناشط المزاح تحقق الاسترخاء والرضا النفسي، مما يحقق للفرد التوازن النفسي (محمد الحماحمي، وعايدة عبد العزيز، 0 . 9 (، صع ب). المطلب الثالث: أهداف المزاح في الإسدلام تتعدد أهدف المزاح في الإسلام ويمكن تتاولها على النحو التالي:

اـ المساهمة في تحقيق التربية العقَََية: العقيدة سلوك إنساني، وليست مجرد معلومات يقينية فقط، فالمؤمن الحق ينطبع سلوكه وتعامله مع نفسه ومع غيره بالشعور الإيماني، من حيث مراقبة الله

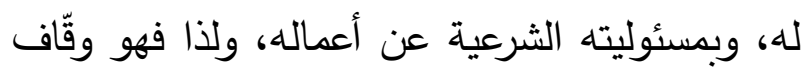
عند حدود الله، مسارع إلى طاعات الله. وعادةً ما يكون الانطلاق والانفلات سمة أساسية في أنماط المزاح، إلا أن المزاح التربوي بما يقدمه من ضوابط يذكر الإنسان بهذا الشعور وبهذه المسئولية، وإذا استطاع الإنسان أن يملك نفسه في مثل هذه المواقف
صع ب)، مما يحقق له مجموعة من الفوائد الجسمية والعقلية والروحية، مباشرة أو غير مباشرة، آنية أم

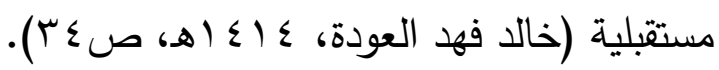
r. الانضباط بالشَّرع الشَّربف: حيث يجب على المسلم خلال ممارسته لأيّ لون من ألوان النشاط المزاحي المختلفة أن يلتزم بحدود ما أباحه الشَّرع المطهَّر ، فلا يتعدّاه إلى غيره من الحرام أو المكروه

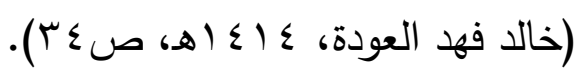
r. الاعتدالية: فلا يجوز أن يطغى وقت المزاح على وقت العمل، ولا أن يؤدي الانشغال به إلى إهمال الواجبات الأخرى، كما لا ينبغي التركيز على نمط واحد من المزاح وإهمال بقية أنماطه؛ مما يؤثر على نمو الفرد نفسيًا بصورة غير متوازنة (خالد فهد

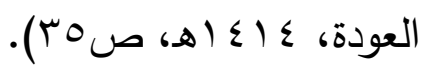
ع. الأمر بالمعروف والنهي عن المنكر: فلا يصح

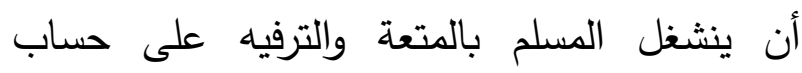
انتهاك حرمات الله تعالى، بإيثار السكوت على أنواع التجاوزات التي لا يقرها الشرع الأغر، كترك صلاة الجماعة لأجل اللعب، أو كثف العورة، أو الاختلاط المحرم، وغيرها من المنكرات (يحيى بسيوني

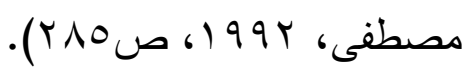
๑. الإشباع: حيث شرع المزاح في الإسلام لإراحة النفس المجهدة، وتجديد النشاط، وإدخال السرور والسعادة على النفس، من خلال الإبداع والتعبير عن الذات في ممارسة النشاط المزاحي، وإلا فيعتبر 
تفكيرهم وتساهم في بنائهم العقلي المستقل (جلال

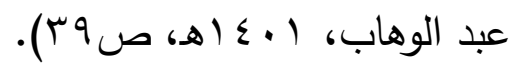

ومن ناحية أخرى فالمزاح التربوي في مساهمته في تتمية القدرات العقلية لا يغفل استغلال مواقف المزاح

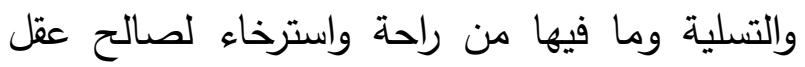
الإنسان ومعارفه، ولذا فهو يسهل عملية التعلم والاكتساب المعرفي، وما ذلك إلا لأن الاسترخاء شرط مهم للتعلم الجيد فالشخص المتوتر لا يكون مستقبلاً ولا مستجيبًا للمثيرات الجيدة، ولذا فالتعليم

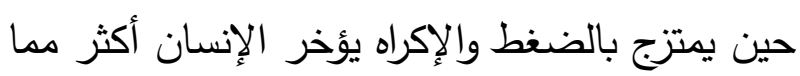
يدفعه للتقدم، فالتعليم الفعال هو التعليم المشوّق

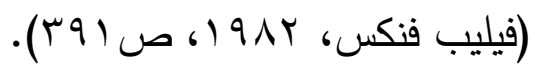
r. المحافظة على الصحة الجسمية:

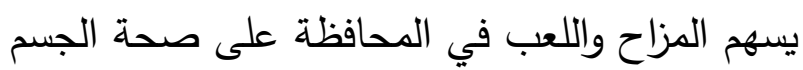
واطِّراد نموه بما يتيحه من رياضات أو حركات تسهح في تحريك وتتمية عضلات الجسم الكبيرة والصغيرة، كما تسهم في تتشيط الوظائف الحيوية للإنسان من خلال إكسابه اللياقة البدنية والقدرات الحركية التي لهي تعمل على تكييف أجهزة الإنسان بيولوجيًّا، ورفع كفايتها الوظيفية. ويؤكد بعض المختصين بالتربية

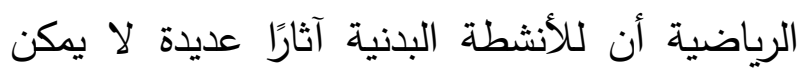

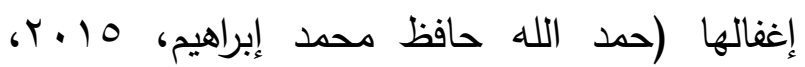
9r). فمن خلال الأنشطة البدنية يكتسب الفرد القوة إئمة

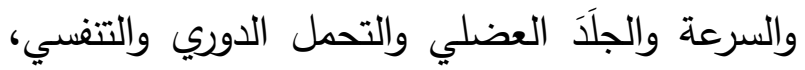

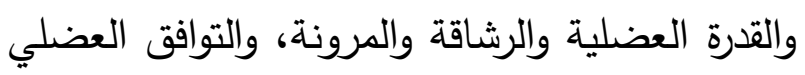

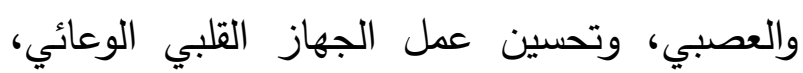

فهو فيما سواها أملك لنفسه، كما أن المزاح التربوي

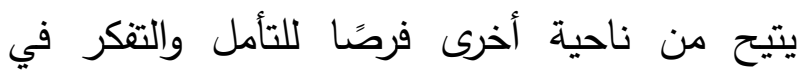
عظمة الله الخالق المبدع، كما يتيح فرصة لإشعار ممارسه بعظمة هذا الدين وشموله وتوازنه وإحكامه

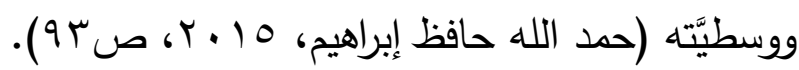
كما أن المزاح التربوي في الإسلام يحُدُّ من غلو

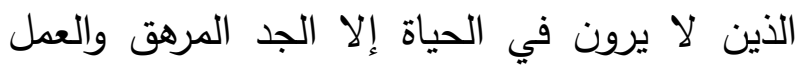
المتواصل، كما أنه يحد من غلو المفرطين الذين يرون الحياة فرصة للمتعة المنطلقة، ويشعر هؤلاء وهؤلاء أن هذا الدين وسط، وأن التوازن مطلوب، وأن قدوتهم رسول الله صلى الله عليه وسلم، كما أن المزاح يسهم في التربية الجهادية، وهي جزء من عقيدة المسلم لا يتجزأ، وسيأتي بيان كيفية هذا لهان

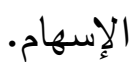
r. - تنمية القدرات العقلية: يسهم المزاح بتدريب وتتمية قدرات الإنسان العقلية، كما يسهم في إبعاد الخمول والكسل الفكري، وزيادة قدرات الإنسان على التركيز والتتكير، وهذا يتجلى في أنماط من المزاح مثل الكتابة الابتكارية والمناقثات والتمثيل (تهاني عبد السلام السيد، •) (1) ( $9 \vee 9$

والمزاح التربوي يتيح أمام الممارسين له طرقًا فعالة

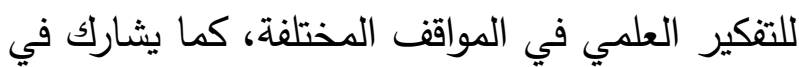
تنمية قدراتهم على التتظيم والتحليل والتفسير والإدراك والملاحظة، ويزودهم بالقدرة على التعبير الدقيق، كما يعرضهم لخبرات ومهارات وأفكار جديدة تثري 
ه. المساهمة في تنمية المهارات المعرفية: أي تعليم يقوم على السماح بقدر جيد من الاسترخاء

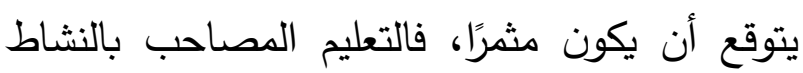

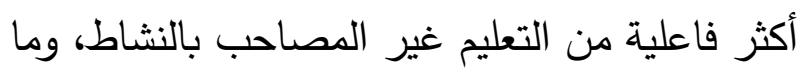
يتعلمه الطالب من خلال رحلة خلوية أو حفلة مسرحية، قد يكون أبقى مما يتعلمه من خلال

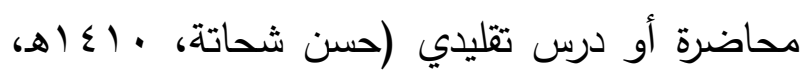

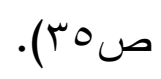

ولا يقتصر دور المزاح التربوي على تهيئة الممارس للتقبل العلمي فقط، بل يتعداه إلى تتمية بعض القيم

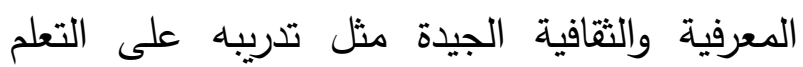
الذاتي، والتعلم المستمر والتتكير العلمي، والعناية

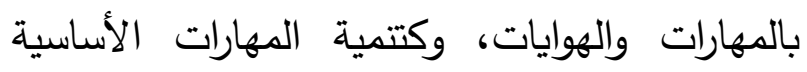
للتعلم، مثل مهارة القراءة والاستماع والمشاهدة ولتهيه والتفكير والمناقثة وغيرها. كما أن المزاح التربوي يؤدي وظيفة تثخيصية، إذ وغيرها.

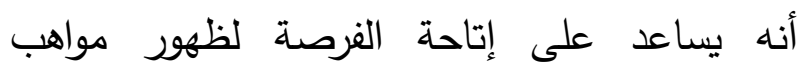
التلاميذ وإبراز ميولهم، فيسهل اكتشاف المواهب، ويعمل على تتميتها وتوجيهها في الاتجاهات السليمة، ويأخذ بيد الموهوبين للنمو في مجالات

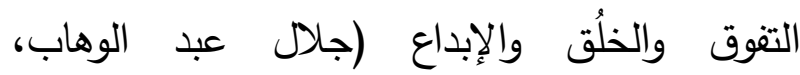

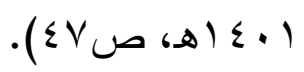

هذا ويمكن القول أيضًا أن المزاح التربوي يسهح

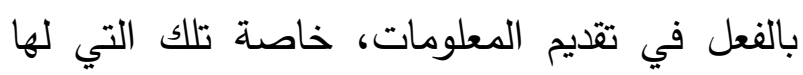
علاقة بنوع النشاط أو تاريخه أو بيئته، أو طريقة النشاط أو ضوابطه وقواعده فالرحلات مثلًا تزود
والتنفس والسعة الحيوية وعمل الكليتين والكبد، وبقية أجزاء الجسم، مما يساعد على الارتقاء بمقومات

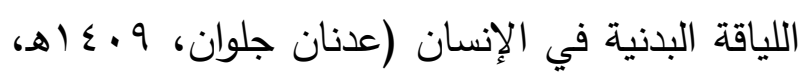

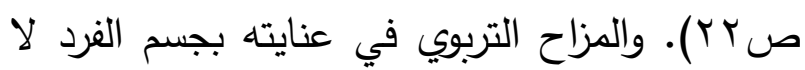
يجعل هذه العناية مبتورة الصلة عن بقية الأهداف ولا يعفيها من الضوابط الشرعية، كما لا يعتبرها الهدف الأول، ولا الهدف الأكثر حظوة ومكانة. ع. المساهمة في الصحة الخُلُقية: للمزاح التربوي إسهامه الواضح في التتمية الخلقية،

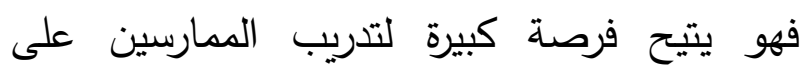
السلوك الإسلامي في العلاقات والمعاملات وفي هلي حالات المرح واللعب كمثل حالات الجِدِّ والعمل. والميزة الأساسية للمزاح في إسهامه في التربية

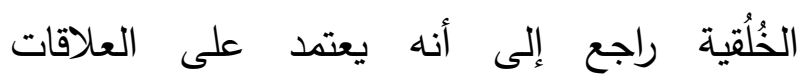
والتفاعلات الطيبة والموجهة والبناءة، وعلى القدوة

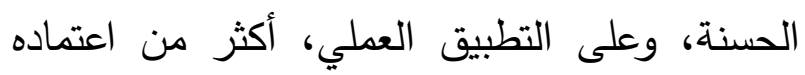

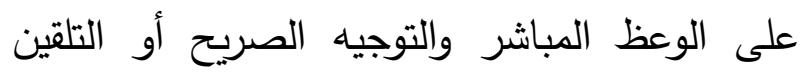

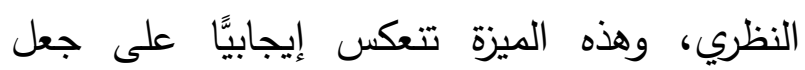

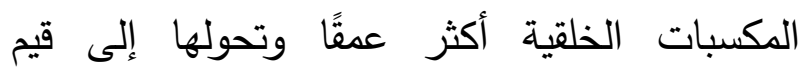
وعادات واتجاهات ثابتة ومميزة لسلوك الإنسان. ومن أهم القيم الأخلاقية التي للمزاح دور مهم في في

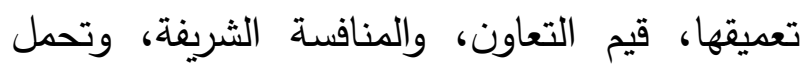

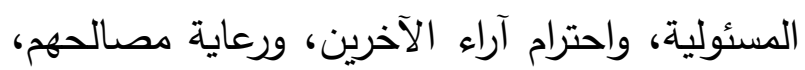

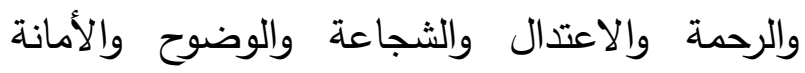

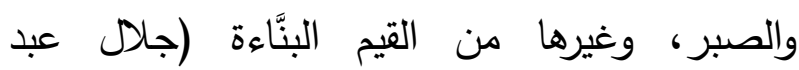

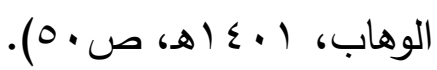


الحياة والناس والمواقف، وهذا من أبرز آثار المزاح،

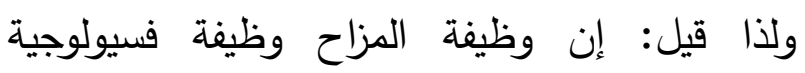
سيكولوجية، وما ذلك إلا لبروز هاتين الناحيتين في

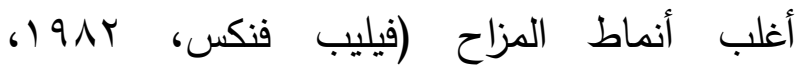

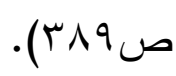

V. الجمية الجانب الاجتماعي:

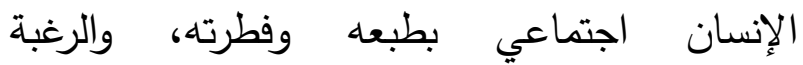
الاجتماعية في الإنسان من أقوى الرغبات، ولذان

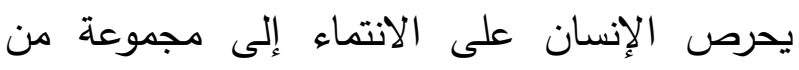

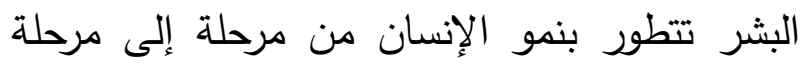

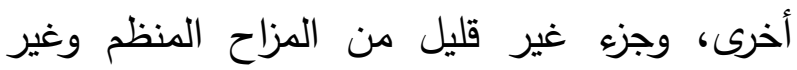
المنظم يعتمد أساسًا على مقابلة الحاجة للانتماء

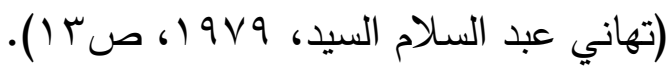

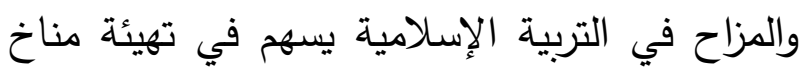

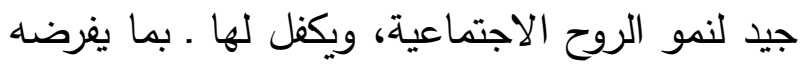
من ضوابط ـ الاستمرار والنمو الإيجابي، وذلك لأنه الأنه ينشئ الممارس على حب الاجتماع وبغض العزلة الإني

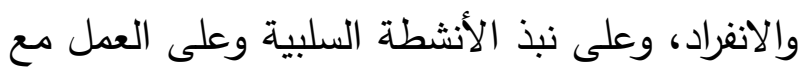
الجماعة، وفي هذا وقاية للفرد من الثعور بالوحدة.

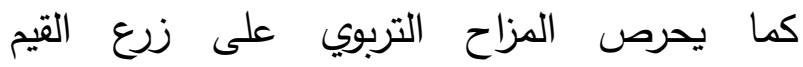
الاجتماعية والأخلاقية الجيدة التي تساهم في تتمية هذا الجانب المهم، فهو يمنع السخرية والإيذاء والظلم

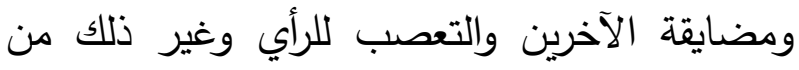

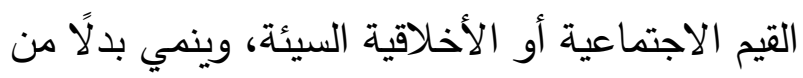

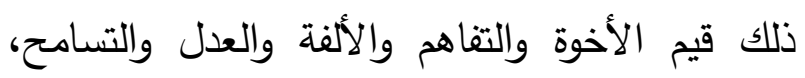

الفرد ـ إضافة إلى الخبرات العملية ـ بمعلومات جديدة عليه، مثل بعض المعلومات الجغرافية والطبيعية، وبعض المعلومات التاريخية والمعلومات التي تتصل لعنل بأساليب السفر وطرق التعامل مع و وسائل المواصلات وخطوات السفر ... إلخ، وهذه الأبعاد

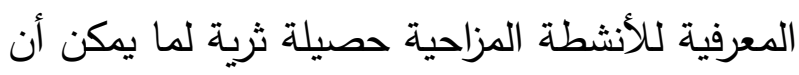

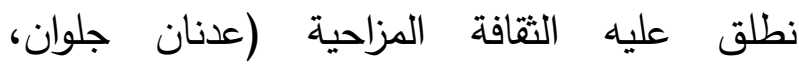
9 צ. تحقيق التوافق النفسي السليم: يسهم المزاح في تخليص الإنسان من التوترات والصراعات الداخلية ويسمح له بالتنفيس عن مشاعره وانفعالاته، وفيه يجد الإنسان إثباعًا لحاجات أساسية لديه، كالحاجة إلى التقدير وتحقيق الذات، وكالحاجة للتعبير عنها، وكالحاجة لتفيس المشاعر والانفعالات، والتخلص من الكبت والإحباط الذي قد يعيشه في فترة من الفترات (حمد الله حافظ إبراهيم، والهن

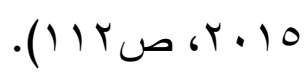
ويرى بعض المتخصصين أن للمزاح آثارًا نفسية أخرى؛ فهو يؤدي إلى تحسين مفهوم الذات النفسية

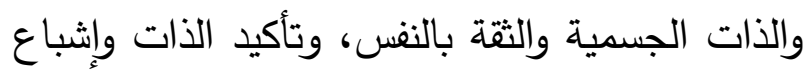
الميول والاحتياجات النفسية والاجتماعية، ويؤدي إلى تتمية مستوى الطموح والتطلع للتفوق والامتياز ، كما يساهم في خبرة النجاح المربِّة (عدنان جلوان،

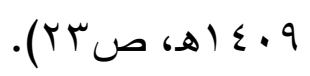
والمزاح التربوي يحمل في ثناياه شعورًا بالسعادة والرضا تمنح الإنسان أفقًا جديدًا يرى من خلادله 
إن المزاح التربوي يساهم بشكل واضح في تتمية

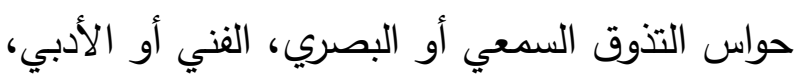

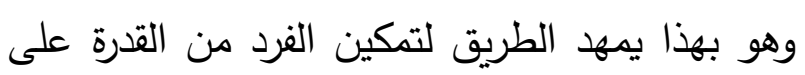
الإبداع البشري المتميز، ومن الاختراع والابتكار

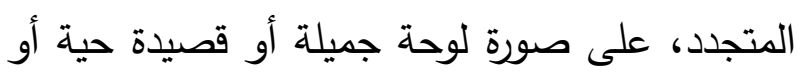

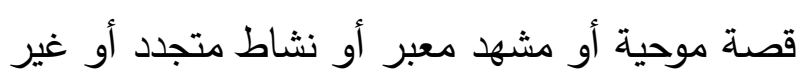
ذلك، فالفرد يعبر عن نفسه وذوقه من خلال هذه

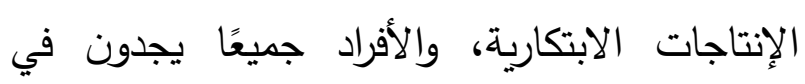
الفنون منطلقًا لقدراتهم وإمكانياتهم وللتعبير عن آرائهم

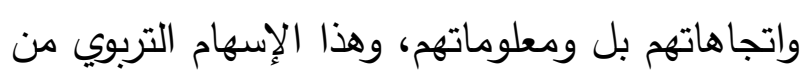
المزاح يصب في محصلته النهائية في زيادة إيمان

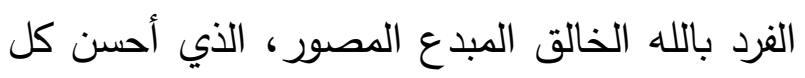

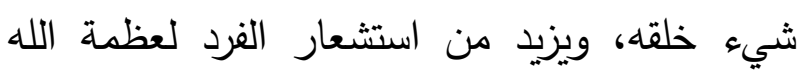

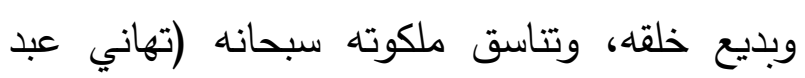

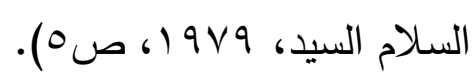

المطلب الرابع: صور من مزاح النبي صلى الله عليه وسلم: ا. عَنْ يَعْلَى الْعَامِرِيّ، أَنَّهُ خَرَجَ مَعَ رَسُولِ اللَّهِ

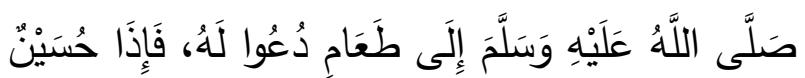

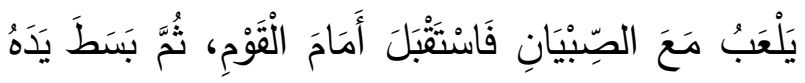

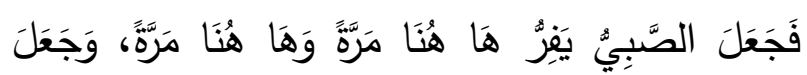

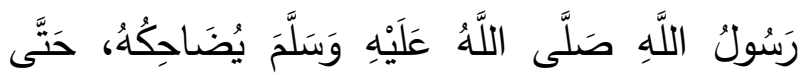

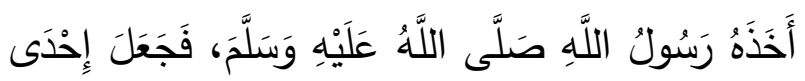

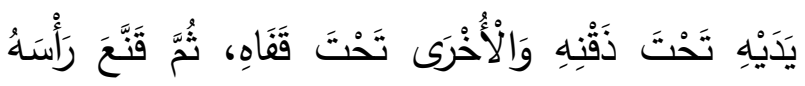

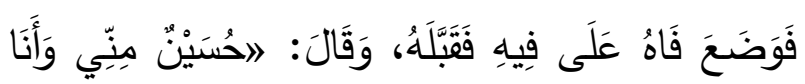

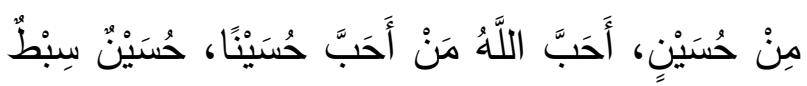

ويُشعر الفرد بكرامته، وبقيمته وبحقه، وكل هذه القيم الاجتماعية والفردية تخدم التربية خدمة كبرى. كما يسهم المزاح التربوي بتوعية الفرد بآداب وقواعد

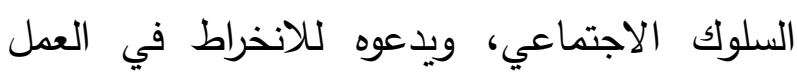
الجماعي ويدربه على أساليب القيادة والتبعية واحترام الأنظمة وتحمل المسئولية. ويضاف إلى كل ما سبق الوظيفة العلاجية للمزاح؛

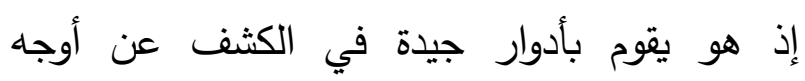
القصور الاجتماعي كحب العزلة والانطواء والسلبية والأنانية وغيرها، ويشارك في علاجها بما يقدمه من الأن

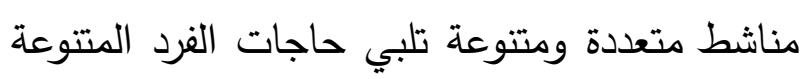
وتدفعه دفعًا إلى المشاركة. ^ـ تنمية الذوق والقدرة على الابتكار: إن جمال الطبيعة ومناظرها الخلابة، وجمال الكلمة

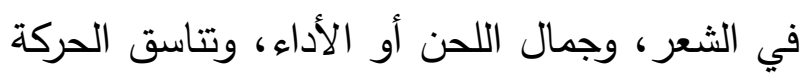

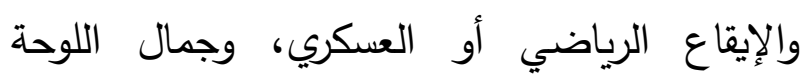

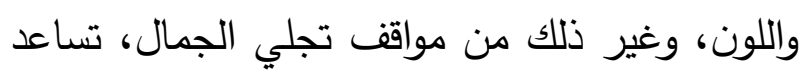
الإنسان على التذوق والإحساس بالجمال من حوله، دوالهي وهذا ذو تأثير كبير على سلوكه، وعلى نظرته

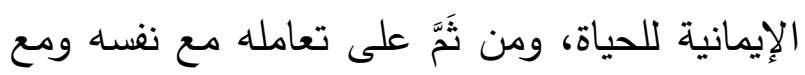

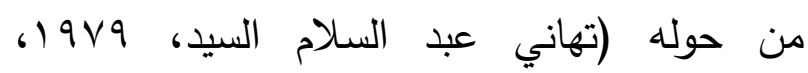

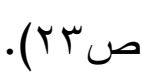
والتذوق الفني يزود الفرد بالقدرة على التقويم، فيوازن

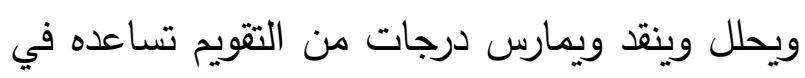

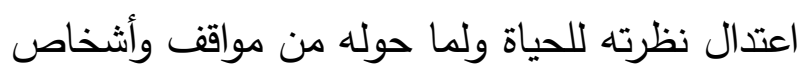

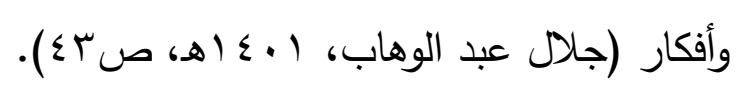




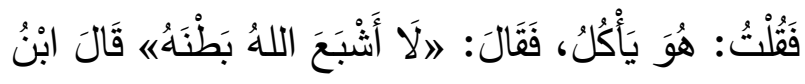

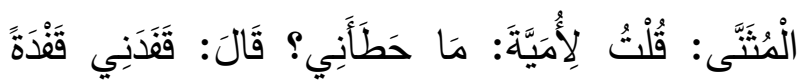

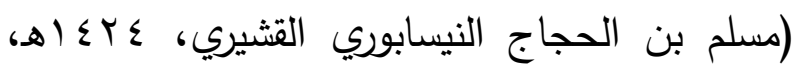
رقم \&.r؟r) (فحطأني حطأة) فسر الزاوي حطأني أي قدني وهو الضرب باليد مبسوطة بين الكتين. في هذه القصة إقرار من رسول الله صلى الله عليه وسلم للعب الصبيان إذ يين الحديث أن النبي مر فر الني

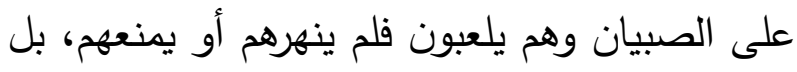

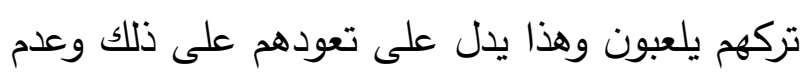

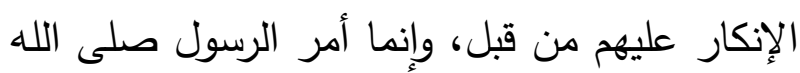

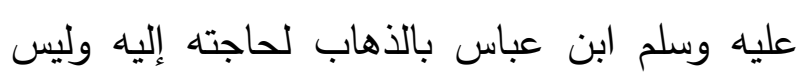

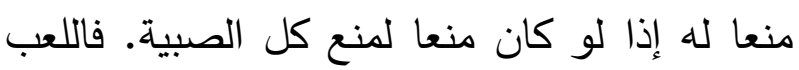

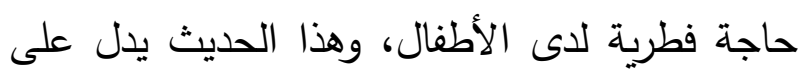

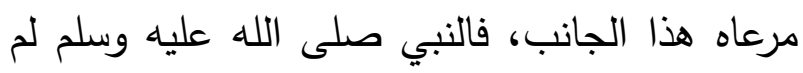
يعاتب ابن عباس على اللعب مع رفتته، ولم يعنفه

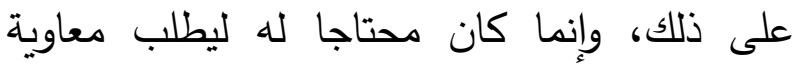
رضي الله عنه، وقد ترك للصبية فرصتهم في تحقيق

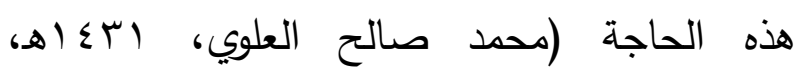
صبر1). يقول النووي (وفي هذا الحديث جواز ترك الصبيان يلعبون بما ليس حرام) (محي الدين

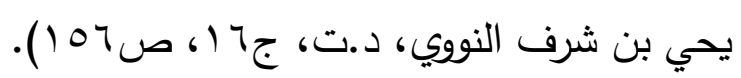

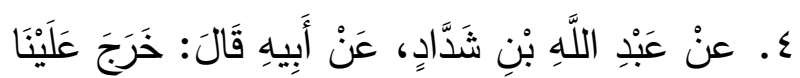

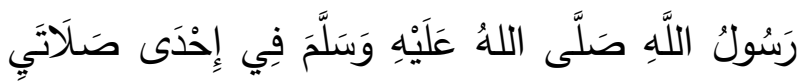

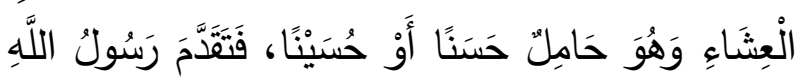

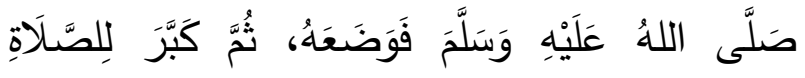

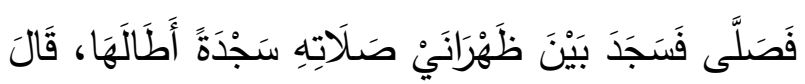

مِنَ الَْسَبَّاطِهِ (محمد بن يزيد ابن ماجة، و9 اهـ،

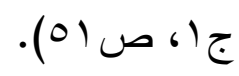
هذه الصورة الرائعة التي جمعت كثير من الخصال (الرحمة، والمحبة، والرفق، والتواضع) حفظت أيضا

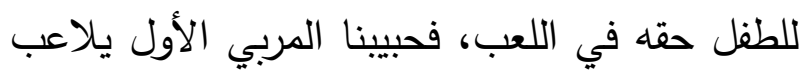
الطفل، ويضمن له حقه في اللعب بل يسايره ويقبله ليقدم صورة مضيئة تبين حفظ التربية الإنلامية للطفل حقه في اللعب.

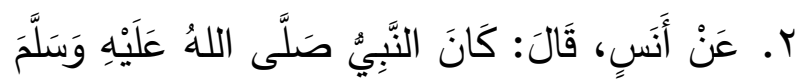

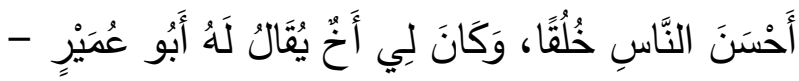

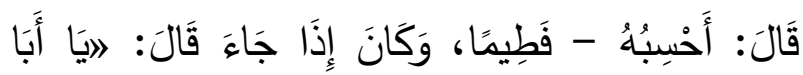

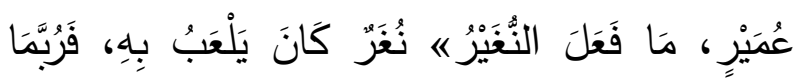

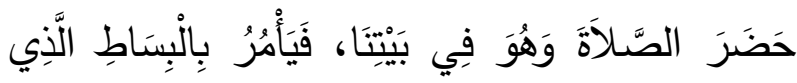

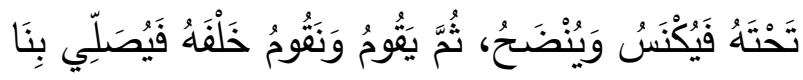

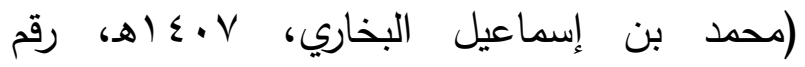
. (Tr.r يقدم الدصطفى صلى الله عليه وسلم نموذجا لرعاية الطفل وحفظ حقه حتى في اللعب، فالطفل (أبو عمير) يحب اللعب بالطير فيقرّه النبي صلى الله عليه وسلم على ذلك بل يداعبه بسؤاله عنه، ليدخل النسرور على قلب الطفل.

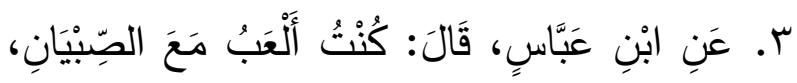

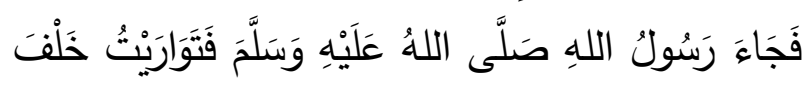

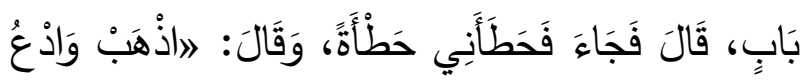

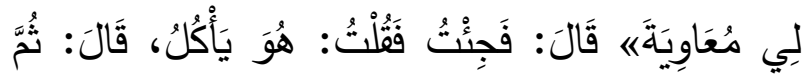

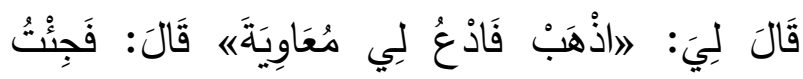


هناك ضوابط شرعية لا بد من مراعاتها عند المزاح،

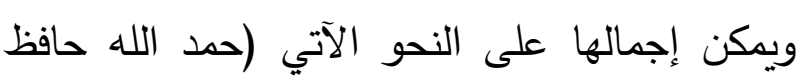

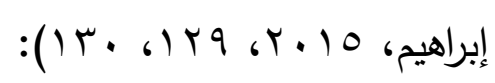

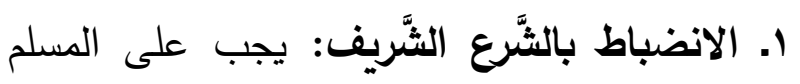

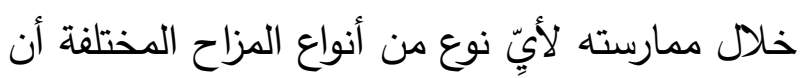

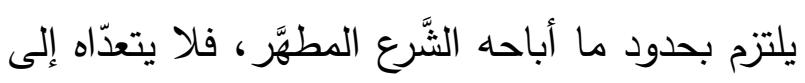
غيره. r. الصدق: فالمزاح في الإسلام لا يقصد إلى اجتلاب الضحك والسرور بأي طريق، ولو كان

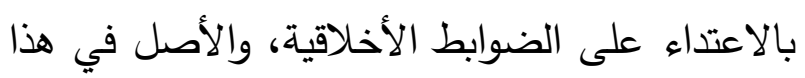
قول الصحابة رضي الله عنهم: يا رسول الله! إنك

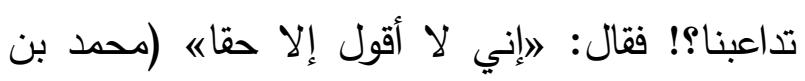

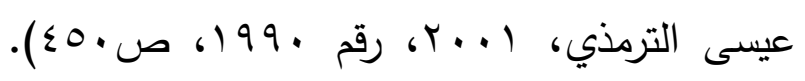

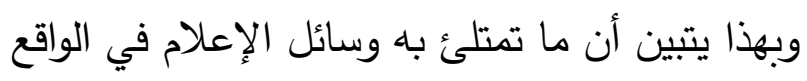

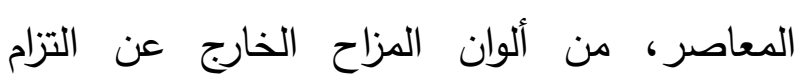
الصدق، أمر يأباه الشرع الثريف ولا يقره.

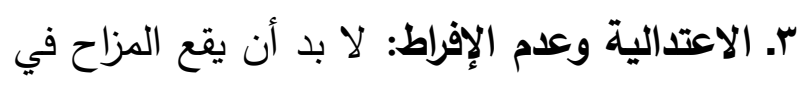
أوقات مناسبة، وبهدف سليم، أما أن يتخذه الإنسان

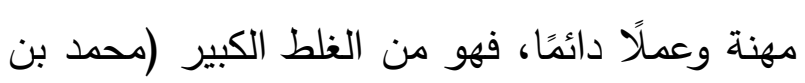

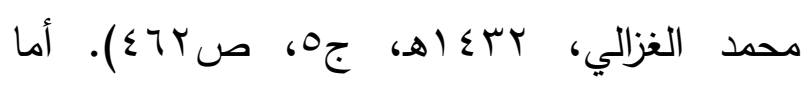

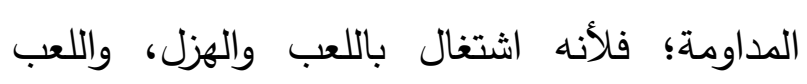
مباح، ولكن المواظبة الدائبة عليه مذمومة، وأما الإفراط فيه؛ فإنه يورث كثرة الضحك، وكثرة الضحك ولك

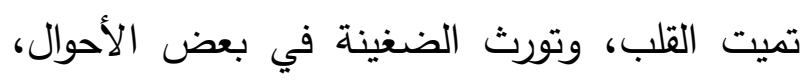

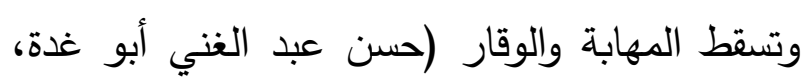

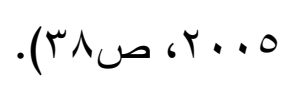

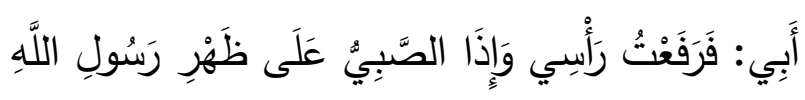

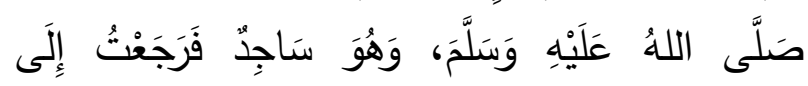

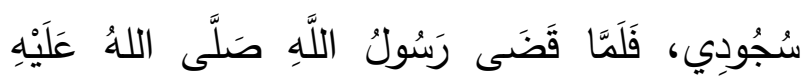

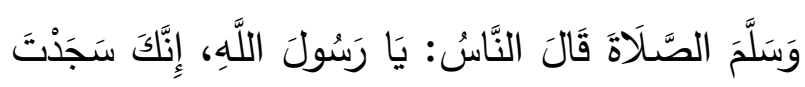

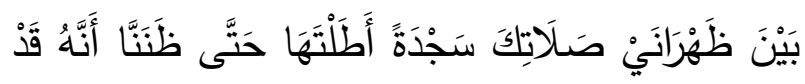

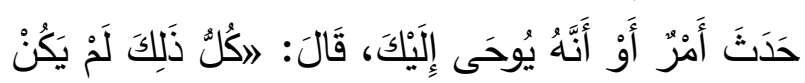

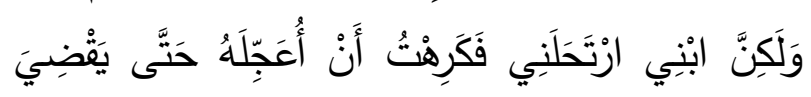
حَاجَتَهُهُ

في هذه القصة تأكيد على أهمية حصول الطفل على فلى

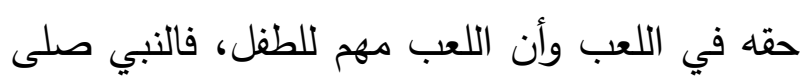
الله عليه وسلم يطيل السجود يشكل يلفت انتباه المصلين حتى ظنوا أن وحيا نزل أو حدث أمر فيبين لهم أنه أطال السجود لأجل أن يتمتع الطفل بحقه كاملا فلا يرفع حتى تنتهي حاجة الطفل، وهذا يؤكد أن اللعب حق من حقوق الطفل ينبغي إعطاؤه كاملا مهما كانت الأسباب.

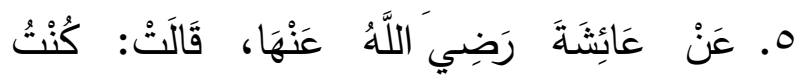

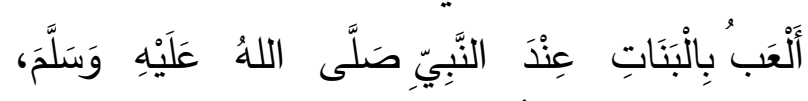

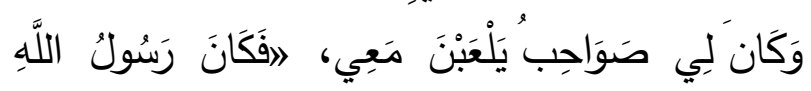

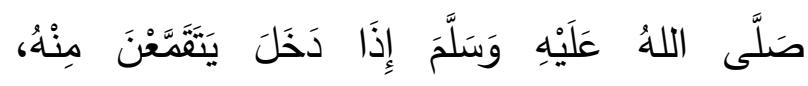

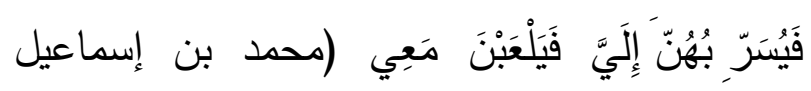

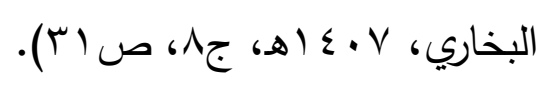
المبحث الرابع: آداب المزاح وأبعاده في الإسلام المطلب الأول: الضوابط التي ينبغي مراعاتها في التراحي المزاح 
إلى هزل (محمد بن محمد الغزالي، بسء اهـ، جه، صט ( )

V. استعمال حسن الفعل والقول في المزاح: بأن يتجنب الكلام الفاحش والبذيء والثقيل الذي لا تقبله النفوس، ويتعد في مزاحه عن القذف أو الغيبة أو النميمة، ويختار من أساليب الكلام أطيبها وأحبها إلى النفوس (أحمد بن علي بن حجر العسقلاني،

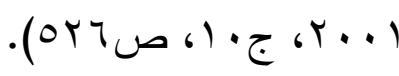

المطلب الثاني: الأبعاد الخُلققية للمزاح في الإسدلام. الناظر في المزاح النبوي ومزاح الصحابة والتابعين رضي الله عنهم؛ يجد في الأحاديث الواردة عددًا كبيرًا من الآثار والأبعاد التربوية، التي يمكن تصنيفها في البعد الخُلُقي، ومن أهم الأبعاد الخلقية ما يلي: ا ـ التحلي بخلق الصبر: يُعد الصبر فضيلة نبيلة من أمهات الفضائل التي تقوم عليها سعادة الفرد والمجتمع، ومن هنا كان نصف الإيمان، بل ربما كان الصبر هو الإيمان

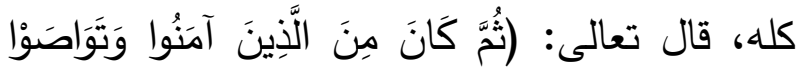

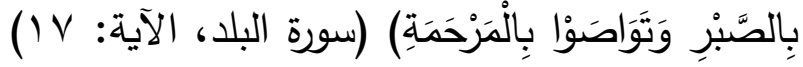
(قاسم غني، د.ت، صع عب). وقد بين الله تعالى ملامح جيل الدعوة القادر على تحمل المسؤولية، فقال: (وَكَأَيَّنْ مِنْ نَبِيّ قَانَلَ مَعَهُ

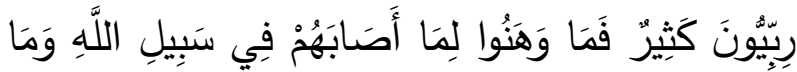
ضَعُفُوا وَمَا اسْتَكَانُوا وَاللَّهُ يُحِبُ الصَّابِرِينَ) (سورة آل عمران، الآية: 7٪ ()). أي وكم من نبي قاتلت معه
ع. تجنب المزاح المحرِّك للأحقاد والضغائن: وقد أشار النبي صلى الله عليه وسلم إلى التلازم الواقع بين المزاح والمخاصمة في كثير من الحالات؛ فقال: 》لا تمار أخالك ولا تمازحه" (محمد بن عيسى

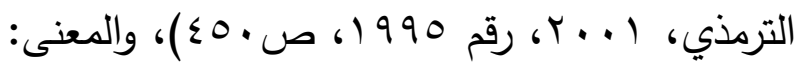
لا تجادل أخالك ولا تخاصمه ولا تمازحه بما يتأذى منه (محمود بن أحمد العيني، ( . . ب، ص997 ()). فما يؤدي إلى تحريك العداوة بين الناس، وإشعال نار الحقد بينهم، أمر مذموم شرعا ولو كان مزاحًا، أو غرضنه المزاح. ه. عدم الترويع والتخويف: حيث شرع المزاح في الإسلام لإدخال السرور والسعادة على النفس، لا لإل لإدخال الخوف عليها، وذلك كأن يحمل طفلاً ويقذفه إلى أعلى بشكل يخيفه، أو يخفي متاعًا لصاحبه يعلم أن قلبه ينخلع عند فقده، أو يلقي على إنسان خبرًا حقيقيًّا ولكن بصورة مروِعة، والأصل في ذلك قول النبي صلى الله عليه وسلم ״لا يأخذ أحدكم متاع صاحبه لاعبًا ولا جادًا، وإذا أخذ أحدكم عصا صاحبه فليردها إليه؛ (سليمان بن أحمد الطبراني، (9 צ. تجنب المزاح مع غير المحارم من النساء: لا سيما إذا كان المزاح مع غير المحارم بابًا إلى

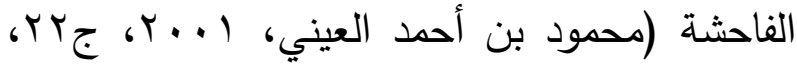
ص 9V). وقد كان مزاحه صلى الله عليه وسلم مع بعض النساء معالجة لضعف قلوبهن، من غير ميل 
غضب أبيها عليها، بلون رقيق من المزاح القولي، أنما،

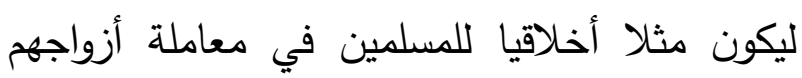
بالصبر والحلم (محمد بن شمس الحق العظيم

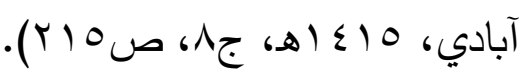

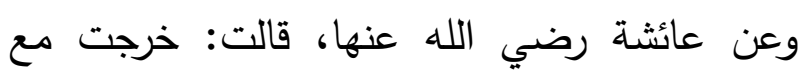

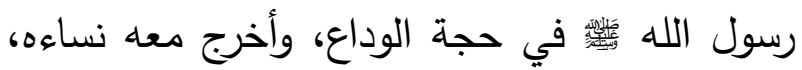
قالت: وكان متاعي فيه خف، وكان على جمل ناج،

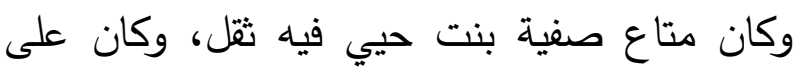
جمل ثقال بطيء يتباطأ بالركب، فقال رسول الله بـان

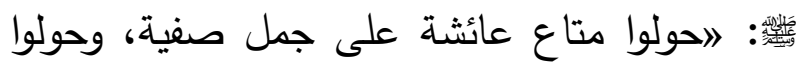
متاع صفية على جمل عائشة، حتى يمضي

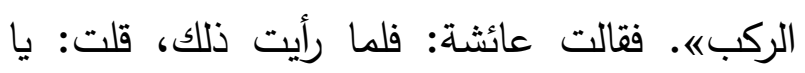

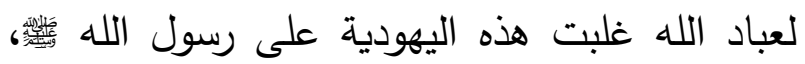

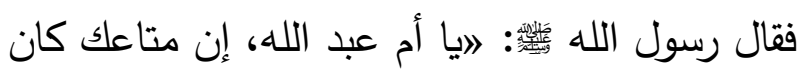
فيه خف، وكان متاع صفية فيه ثقل، فأبطأ بالركب،

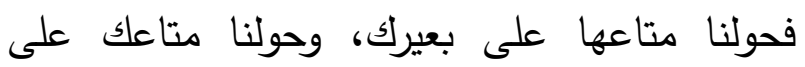
بعيرهاه، قالت: فقلت: ألست تزعم أنك رسول الله؟ فتبسم، وقال: 》أفي شك أنت يا أم عبد الله؟هاء، قالت: ألست تزعم أنك رسول الله؟، فهلا عدلت. وسمعني أبو بكر، وكان فيه غرب، أي حدة، فأقبل

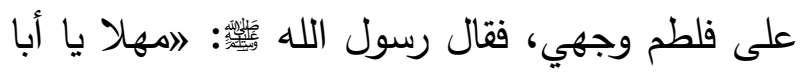
بكر «، فقال: يا رسول الله، أما سمعت ما قالت

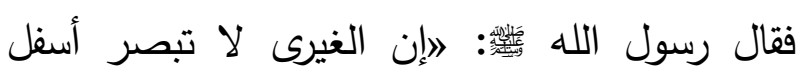

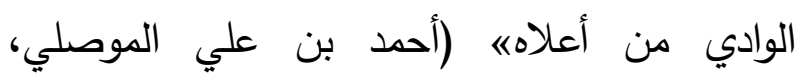

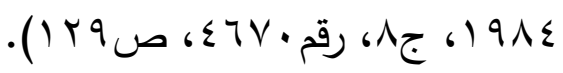

جماعات كثيرة، فما ضعفت نفوسهح لما أصابهح من

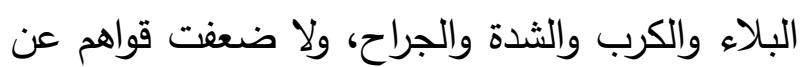
الاستمرار في الكفاح، وما استسلموا للجزع ولا

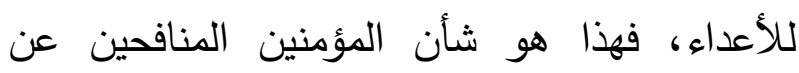

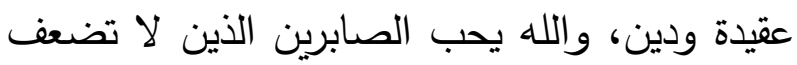
نفوسهم ولا تتضعضع قواهم ولا تلين عزائمهم ولا يستكينون أو يستسلمون. ويتجلى ذلك البعد الأخلاقي في عدد من الأحاديث الدالة على المزاح، حيث يظهر فيها بوضوح تام، صبر رسول الله صورها، من صبر على الزوج، والصاحب، والخادم.

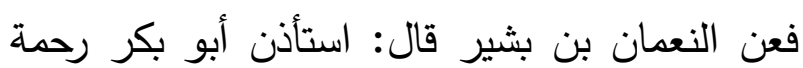

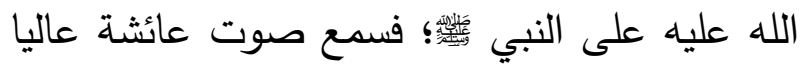
وهي تقول: والله لقد علمت أن عليَّا أحب إليك من أبي، فلما دخل تناولها ليلطمها، وقال: لا وأراك

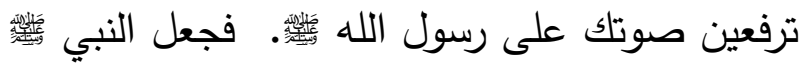

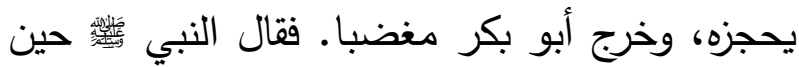
خرج أبو بكر: ״كيف رأيتني أنقذتك من الرجلهـ قال: فمكث أبو بكر أياما ثم استأذن على رسول الله

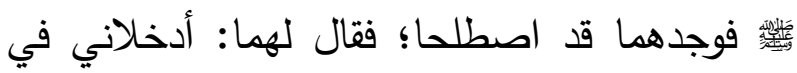

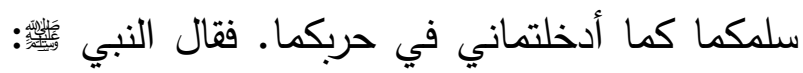
》قد فعلنا.. قد فعلنا《 (سليمان بن أبي داود

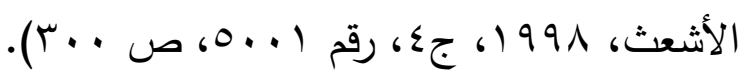

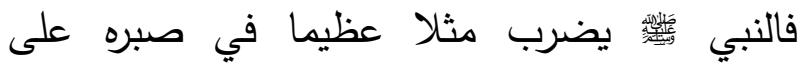
زوجته، إذ يحتمل منها رفع صوتها، ثم يتحمل هبل جفوتها وغضبها، بل ويسعى في تطييب خاطرها بعد 
r. ب. التحلي بخلق الصدق قولاً وعملاً: يمثل الصدق ذروة الأخلاق، وأعلى مراتبها، لذلك وعملك

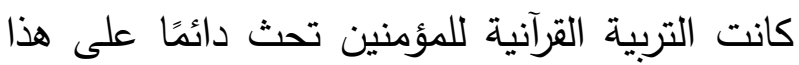
الخلق، فجاءت أغلبها في سياق تكريس الصدق كمنهج تقوم عليه حياة المؤمن في سكناته وحركاته،

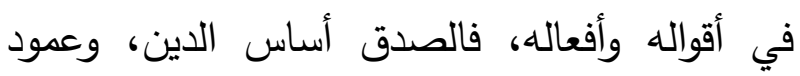

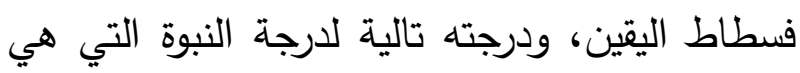
أرفع درجات العالمين، وبالصدق يميز أهل النفاق

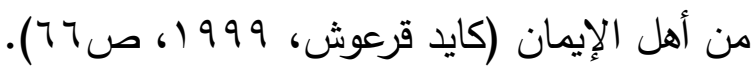
ويقول عز وجل في محكم التنزيل: (طَاعَةُّ وَقَّوْلِّ

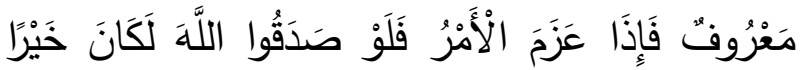

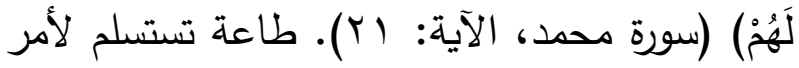
الله عن طمأنينة، وتتهض بأمره عن ثقة، وقول معروف يشي بنظافة الحس، واستقامة القلب، وطهارة الضمير، وأولى لهم إذا عزم الأمر، وجدّ الجد، لهُ

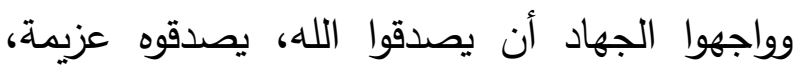
ويصدقوه شعورًا، فيربط على قلوبهم، ويشد من عزائمهم، ويثبت أقدامهم، وييسر المشقة عليهم. وتأتي التوجيهات القرآنية للمؤمنين ليلتزموا بمنهج الصدق في حياتهم وأخلاقهم وسلوكياتهم، فقال

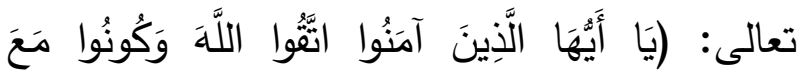
الصَّادِقِينَ) (سورة التوبة، الآية: 9 (1) (1). وقد نزلت إِلت هذه الآية بحق الذين تخلفوا عن رسول الله في له موقعة تبوك، ومنهم كعب بن مالك رضي الله عنه،

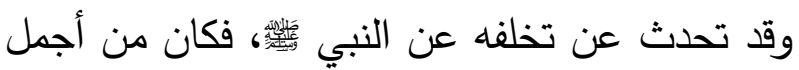
ما ورد في حديثه قوله وقد أدرك قيمة الصدق من

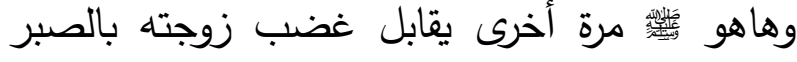
الجميل، بل ويعالج ذلك الغضب باللين والحكمة، حتى إذا رأى أبا بكر يغضب لما يرى من فعل ابنته، يقول له: 》ههلا《، داعيا إياه إلى الصبر والحلم

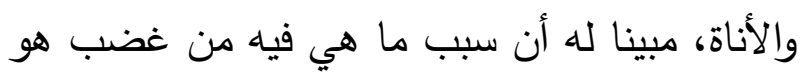
الغيرة، والغيرى لا تفرق بين الحق والباطل والصواب والغلط، بل لا تكاد تبصر أسفل الوادي من أعلاه، لما يغلب على عقلها من شدة الغيرة (الحسين بن

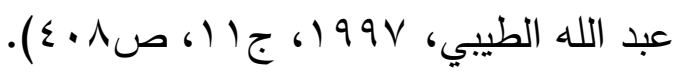
وعن أنس قال: كان رسول الله جله من أحسن الناس

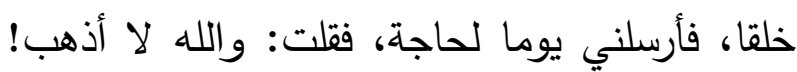
وفي نفسي أن أذهب لما أمرني به نبي الله فئسئ.

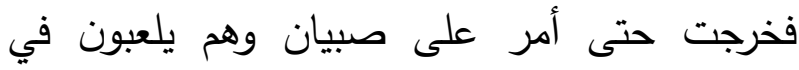

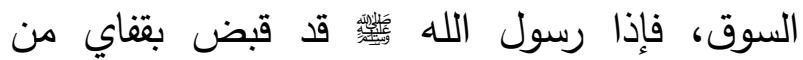
ورائي، قال: فنظرت إليه وهو يضحك، فقال: يا لإن أنيس أذهبت حيث أمرتك؟ قال: قلت: نعم أنا أذهب لصب يا رسول الله (مسلم بن الحجاج النيسابوري القشيري،

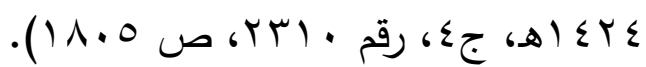
ومرة ثالثة يظهر الصبر على خادمه في معنى لطيف، فلا يقابل استهانة خادمه الصغير بأوامره، ولهوه عن حاجاته بالعقاب والثدة، بل بالحلم والصبر، فلا يفزعه، ولا يقهره، بل لا يزيد على بلى بعاب إرشاده إلى امتثال الأمر الذي كلفه به (محي الدين يحيى بن شرف النووي، د.ت، جل، صـ1 • ( ). 
إن الصدق هو الذي يشكل المسلم الحقيقي بأخلاقه

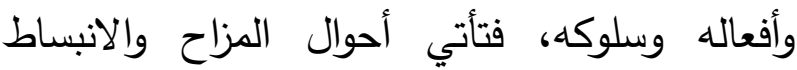
لتظهر حقيقة هذا الصدق في قلبه، فهذه القلوب يكثف مخبؤها أمثال تلك الأحوال التي يغلب عليها التبسط وعدم الانتباه، فهذه التربية القرآنية هي التي توجه وتربي وتزرع القيم والمفاهيم في القلوب. وقد تجلى هذا البعد التربوي في عدد من الأحاديث الخاصة بالمزاح. فعن أنس رضي الله عنه، أن رجلا

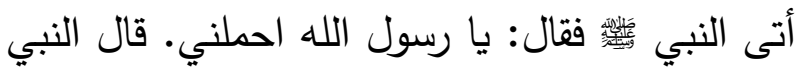

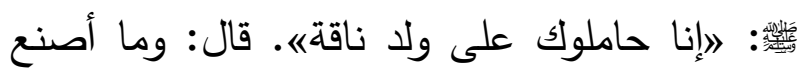
بولد الناقة!! فقال النبي النُوقُهُ (أحمد بن حنبل الثيباني، د.ت، جَّ، رقم ( )

فهو يمزح مع صاحبه في وقت ربما يظن الإنسان أنه ليس من أوقات المزاح والمداعبة؛ إذ هو وقت ولت لهن الاستعداد للقتال مع العدو، والرجل قد جاء ليحمله

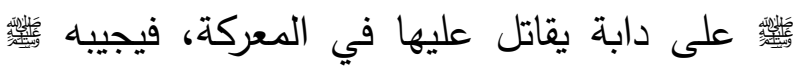
بقوله: 》إنا حاملوك على ولد ناقة《، فيتوهم الرجل

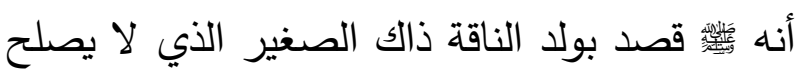

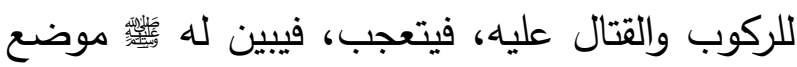

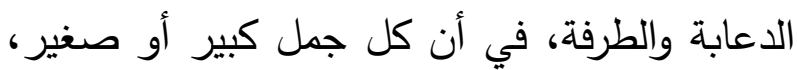
ما هو إلا ولد ناقة، وهو في هذا لا يقول إلا حقا، ولا

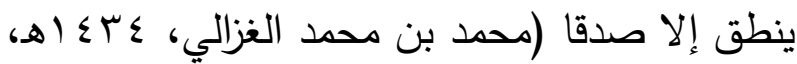

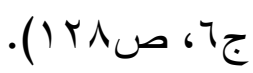

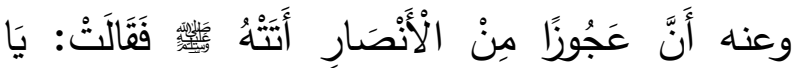

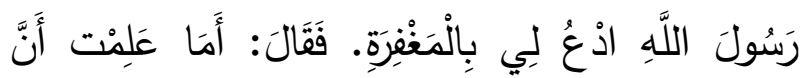

خلال الابتلاء الذي تعرض له: 》افقلت: يا رسول الله إن الله إنما نجاني بالصدق، وإن من توبتي أن لأن

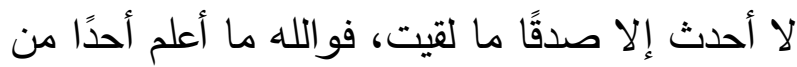
المسلمين أبلاه الله في صدق الحديث منذ ذكرت ذلك لرسول الله

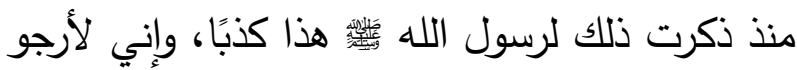
أن يحفظني الله فيما بقيته (محمد بن إسماعيل

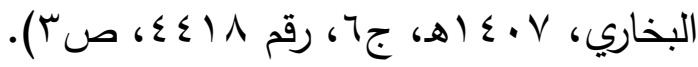
ولفظ الصدق يستعمل في ستة معان: صدق القول، وصدق النية والإرادة، وصدق العزيمة، وصدق لنقان الوفاء، وصدق العمل، وصدق في تحقيق مقامات الدين، فمن اتصف بالصدق في جميع ذلك فهو صديق؛ لأنه مبالغة في الصدق (محمد بن محمد

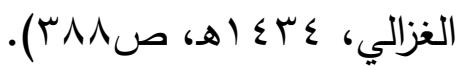
وقسّم بعضهم الصدق إلى ثلاثة أقسام، هي: الصدق صن

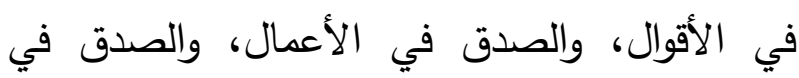

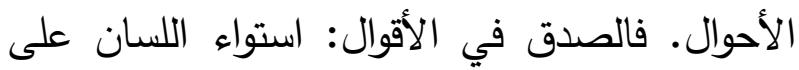

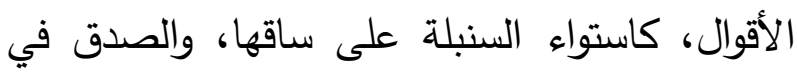
الأعمال: استواء الأفعال على الأمر والمتابعة، الهاء كاستواء الرأس على الجسد، والصدق في الأحوال:

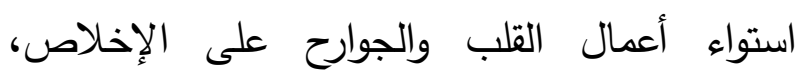
واستقراغ الوسع، وبذل الطاقة، فبذلك يكون العبد من

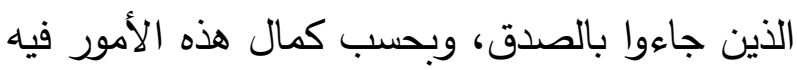
وقيامها باه تكون صديقتيه (محمد بن أبي بكر بن بن

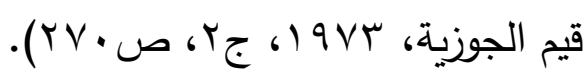




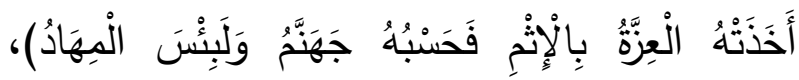

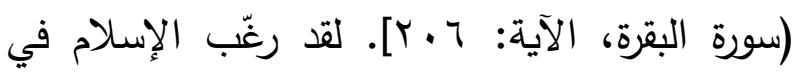
التواضع وحث عليه، وأثنى على المتواضعين، وحذّر من الكبر، لأنه من أقبح الانحرافات الخلقية وأسوأها

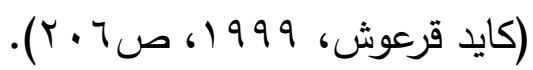

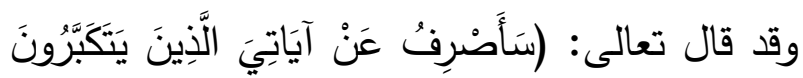

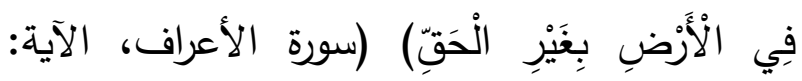

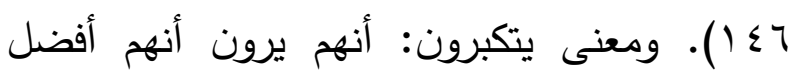
الخلق، وأن لهم من الحق ما ليس لغيرهم، وهذه الصفة . أعنى التكبر ـ لا تكون إلا لله تعالى، لأنه لئه

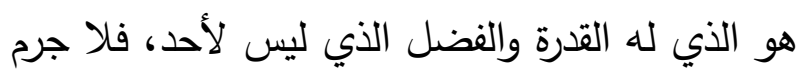
يستحق كونه الدتكبر ، وقال بعضهم: التكبر : إظهار كبر النفس على غيرها، وصفة التكبر صفة ذم في جميع العباد، وصفة مدح في الله جل جلالهاله، لأنه يستحق إظهار ذلك على من سواه، لأن ذلك في حقه جلى حق، وفي حق غيره باطل (محمد بن أبي بكر لإن

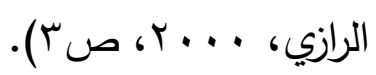

ووردت في السنة النبوية المطهرة أحاديث كثيرة للتتنير والترهيب من الكبر ، فمن ذلك ـ مثلا ـ قول

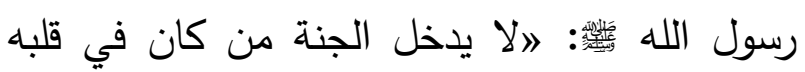
مثقال ذرة من كبره (مسلم بن الحجاج النيسابوري

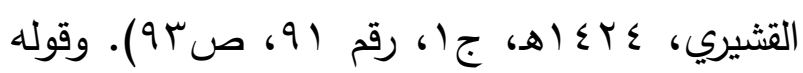

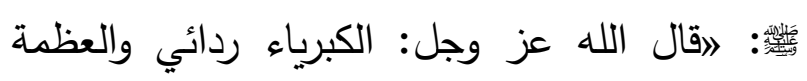
إزاري، فمن نازعني واحدًا منهما قذفته في النار هان

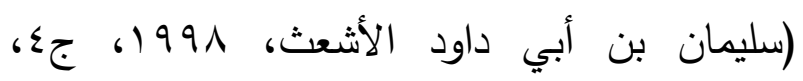

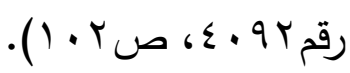

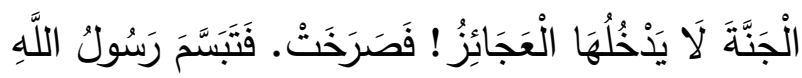

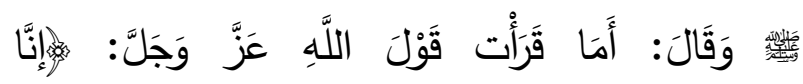

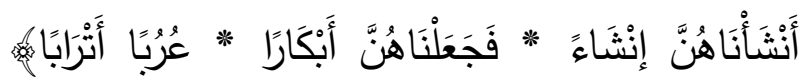

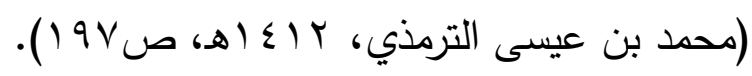

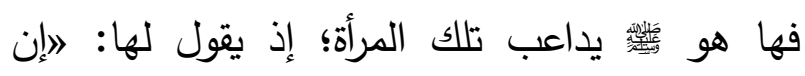
الجنة لا يدخلها العجائزه، وهو حق لا شأبك فيه، وصدق ليس بكذب، ثم يرجع فيشرح لها أنها يومئذ

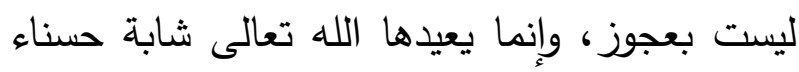

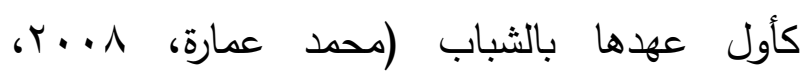
صغ (1) ( ).

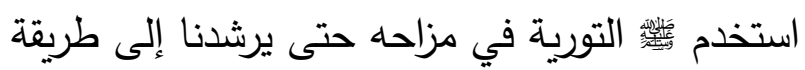
الابتعاد عن الكذب فيه. وقد قال له صحابته رضي فئه

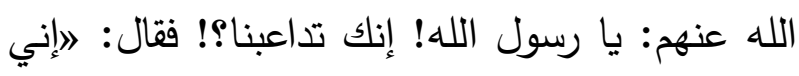
لا أقول إلا حقاه (محمد بن عيسى الترمذي،

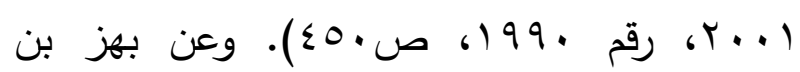
حكيم، عن أبيه، عن جده قال: سمعت رسول الله بـ يقول: اويل للذي يحدث فيكذب ليضحك به به القوم،

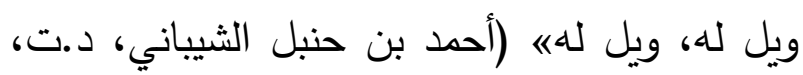

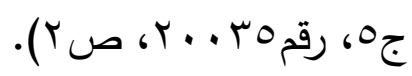
ب. التحلي بالتواضع وترك الكبر: يُعد التواضع من القيم الخلقية التي ينبغي أن يتحلى بلئ

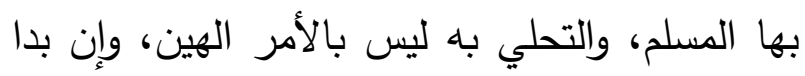
للوهلة الأولى أنه خلق يمكن التحلي به، غير ألن النهان

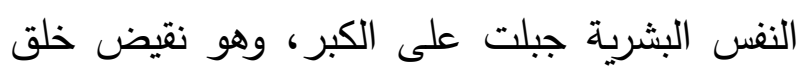

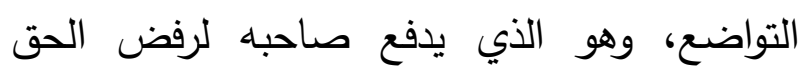

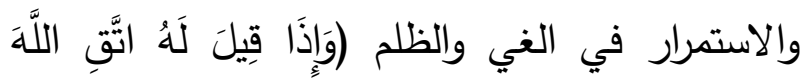


الأخلاق، وهو يكمل صاحبه بجميل الخصال، وقد وعد الله تعالى الصبر على تحمل الأنى والمغفرة

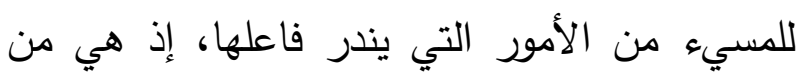

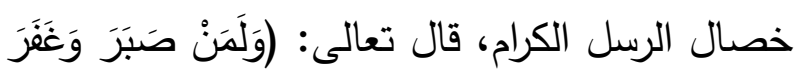

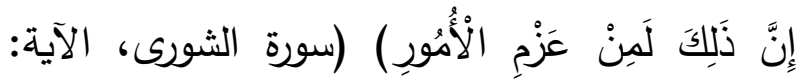

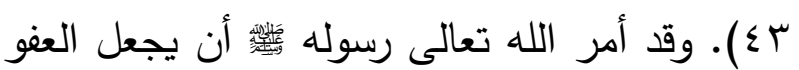

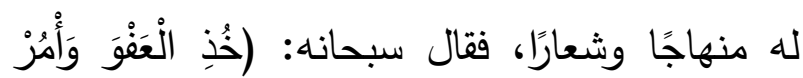

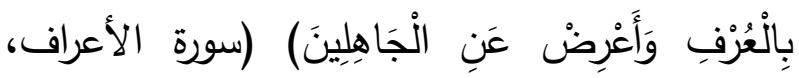
الآية: 99 (1). والجزع وعدم تحمل الأذى من صفات الحمقى وأهل الطيش، ودليل عدم الرزانة وفقدان الاتزان، وصفة الحلم علامة مميزة بين إنسان ذي ودي عقيدة راسخة وإيمان قويم، وآخر تتقصه هذه المزايا

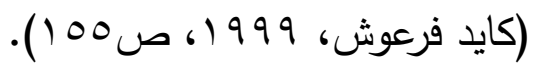
وتحض التوجيهات القرآنية على الالتزام والتحلي بخلق الحلم والعفو، وليس هناك أدل من حادثة الإفك

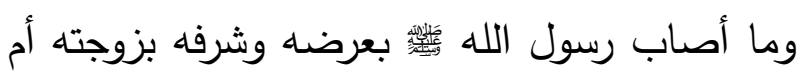
المؤمنين عائشة رضي الله عنها، فقد كان تعامل النبي العفو والحلم حتى عفوا عمن تكلم بعرضهما وشرفهما، وهذا ما يعجز الإنسان أن يصل إليه، فقد

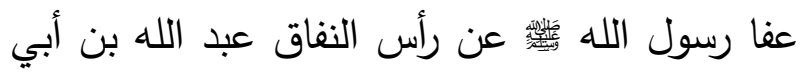

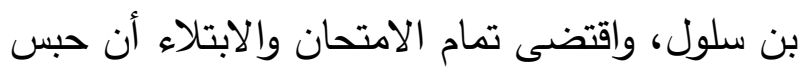

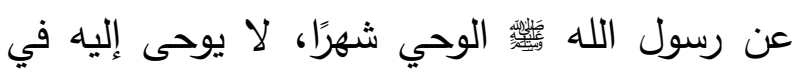
ذلك شيء، لتتم كلمته التي قدرها وقضاها وتظهر لتهري على كل الوجوه، ويزداد المؤمنون الصـادقون إيمانًا وثباتًا على العدل والصدق وحسن الظن بالله ورسوله
ويدور الكبر على ثمانية أسباب، وهي: العلم، والعمل والعبادة، والحسب والنسب، والجمال، والمال، والقوة

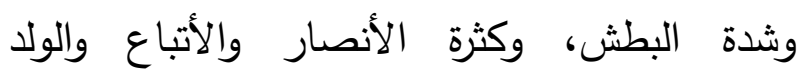
والعشيرة، والغرور والوهم (كايد قرعوش، 999 19،

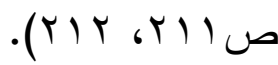
وكثير من العلماء أشار إلى كيفية الخلاص من داء

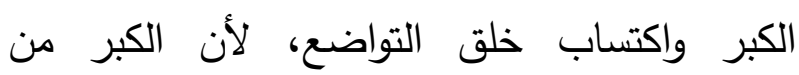

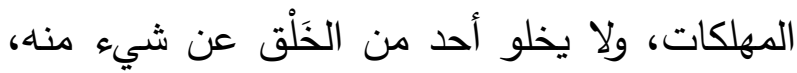
وإزالته فرض عين، ولا يزول بمجرد التمني، بل بل بل

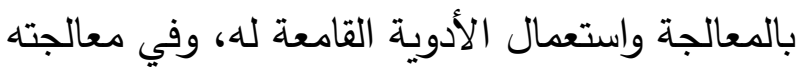

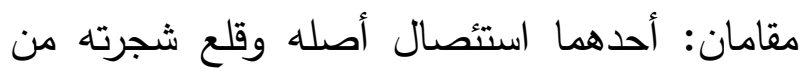
مغرسها في القلب، والثاني دفع العارض منه بالأسباب الخاصة التي بها يتكبر الإنسان على غيره

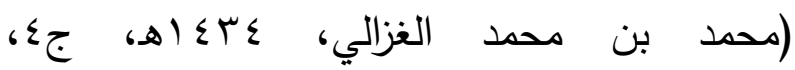

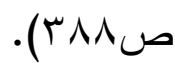
فالتواضع من أعظم ما يتخلق به المره، فهو جامع

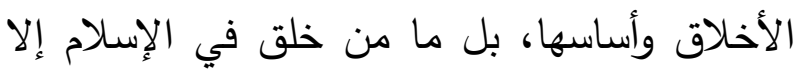
وللتواضع منه نصيب، فبه يزول الكبر، وينشرح

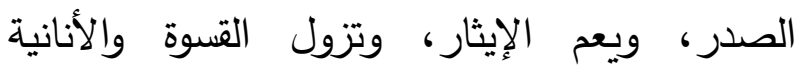
والتشفي وحب الذات. فيقول تعالى: (وَعبََادُ الرَّحْمَنِ

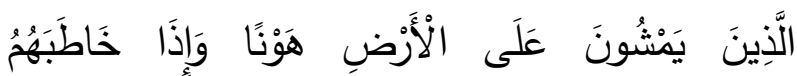

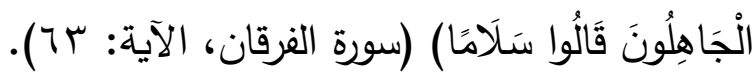
ـ. ـ التحلي بخلق العلم والعفو والصفح: الحلم هو ضبط النفس عند ثورة الغضب، حال وجود ما يدعو إليه، وتملك عنانها حذار الاسترسال في هيجائها فيحدث ما لا تحمد عقباه، والحلم سيد 


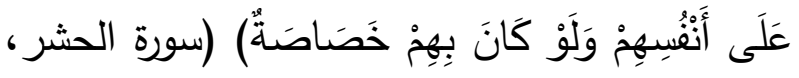
الآية: 9) (مسلم بن الحجاج النيسابوري التشيري،

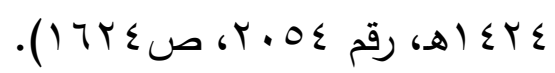
فخلق الكرم من الخلال النبيلة التي ينبغي أن يتحلى الألى

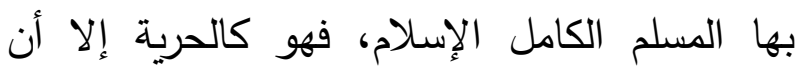
الحرية قد تقال في المحاسن الصغيرة والكبيرة، والكرم لا يقال إلا في الكبيرة كإنغاق مال في تجهيز جيش الغزاة، ونحوه. ويندرج الكرم في الإسلام تحت نداء البر والتقوى في باب المشاركة والدعاونة والترابط، ويندرج تحته العمل الصالح في مجموعه. لقد جاءت التوجيهات القرآنية والنبوية للتحلي بالإيثار

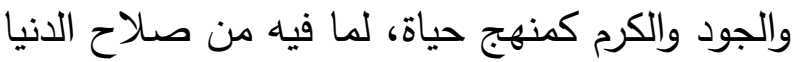
والآخرة، وبنفس القدر كان التحذير الرباني والنبوي من البخل والثح بما يحمله من آثار مدمرة للمجتمع.

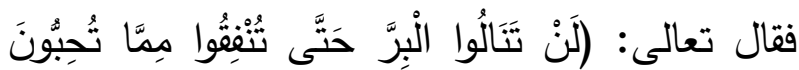

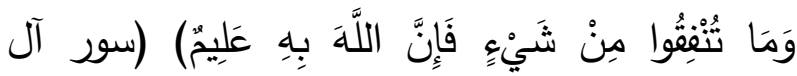

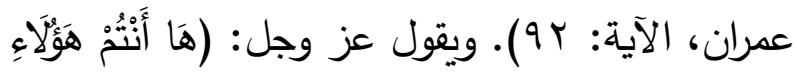

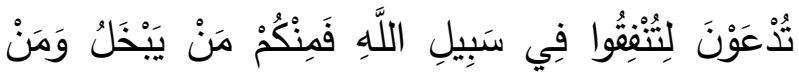

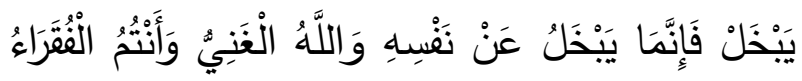

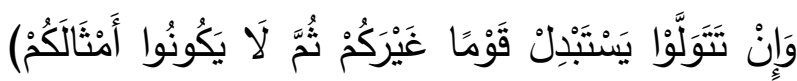
(سورة محمد، الآية: ^یץ).

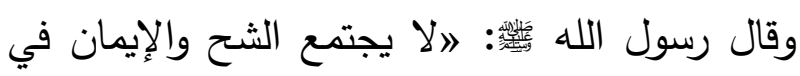
قلب عبد أبدًاء (أحمد بن حنبل الثيباني، د.ت،

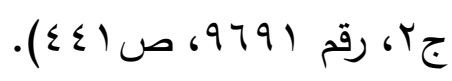
ويظهر الإيثار والجود في مظاهر شتى من سلوك المسلم، وهو بمفهومه العام والأشمل يعني إيثار
وأهل بيته والصديقين والصالحين من عباده، ويزداد

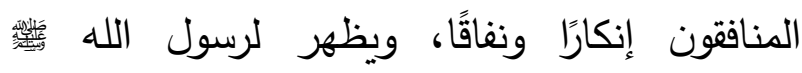

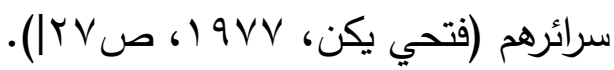
وليس أعظم من الموقف التاريخي الإنساني في فتح

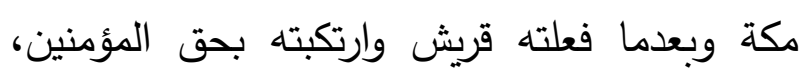

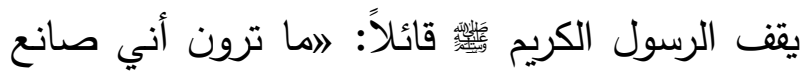
بكم؟ه قالوا: خيرًا! أخّ كريم، وابن أخِ كريم، قال: ״اذهبوا، فأنتم الطلقاءه (أحمد بن الحسين البيهقي،

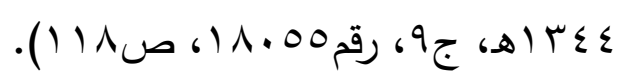
ه. التحلي بخلق الكرم والبذل والإيثار: يعد الجود والبذل والإيثار والسخاء والعطاء معاني لخلق وقيمة إنسانية واحدة، يقابلها الثخح والبخل والحرص والأثرة. فالجود والسخاء والإيثار بمعنى

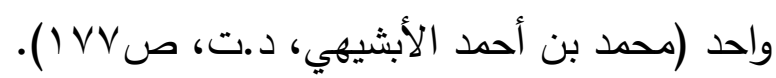
وقيل: الإيثار هو تقديم الغير على النفس وحظوظها

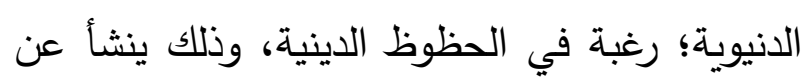

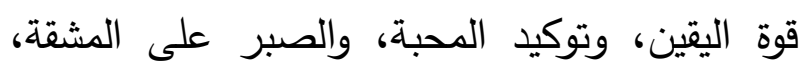
يقال: آثرته بكذا، أي: خصصته به وفضلته (محمد

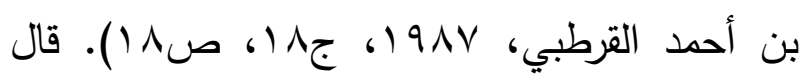

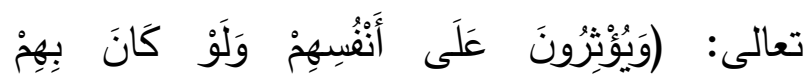

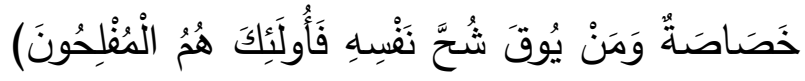

$$
\text { (سورة الحشر ، الآية: 9). }
$$

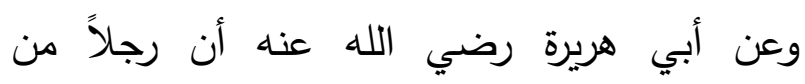
الأنصار بات به ضيف فلم يكن عنده إلا قوته وقوت رضات

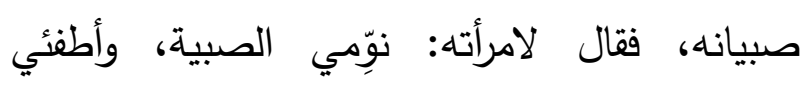

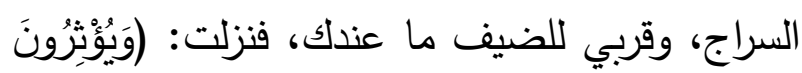


7. . تحقيق القدوة الحسنة والنموذج الصادق:

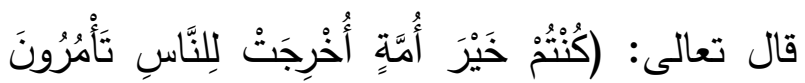

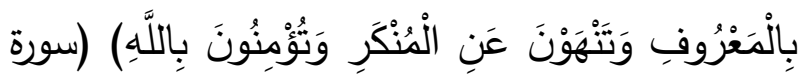

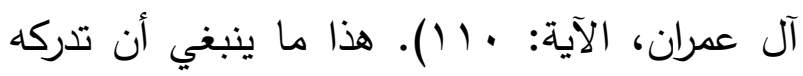

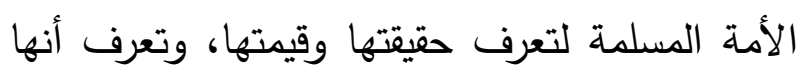
أخرجت لتكون طليعة، ولتكون لها القيادة بما أنها خير أمة، والله يريد أن تكون القيادة للخير لا للشر في هذه الأرض.

ويجب على هذه الأمة أن تكون نموذجًا صادقًا

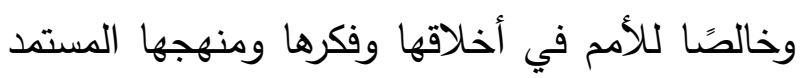
من الله عز وجل، بحيث تمثل بأخلاقها ومنهجها

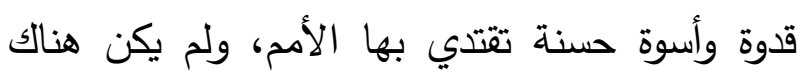

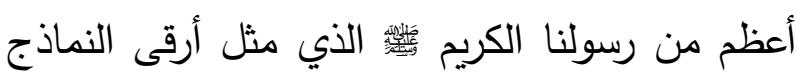

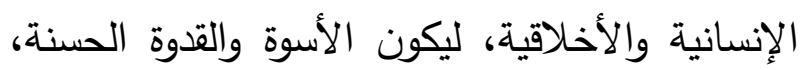

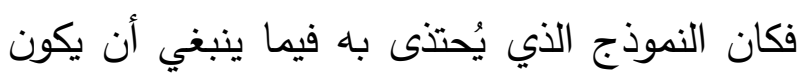
عليه حال الفرد المسلم. وقد أثار القرآن الكريم إلى أهمية القدوة الحسنة في

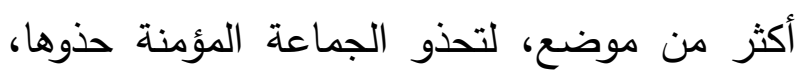

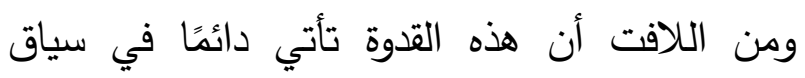
الصراع بين الحق والباطل، وفي سياق الدحن

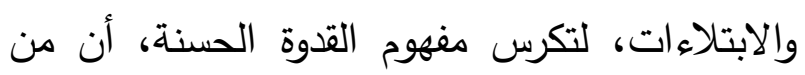
يحمل هذا المنهج لديه من الإمكانات والطاقات والمؤهلات الأخلاقية والفكرية أن يكون بحق نموذجًا

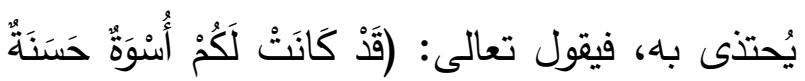

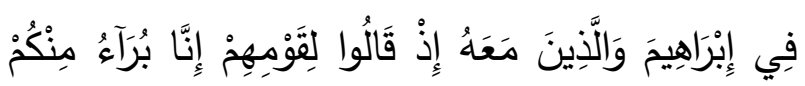

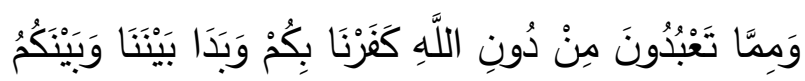

الآخرة على الدنيا، والتي يندرج تحتها كل معاني الإيثار والجود في الحياة الدنيا، بدءًا من الجود بالنفس من أجل الله، وانتهاء بالجود بالمال وإنفاقه

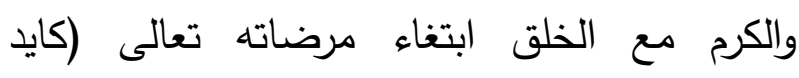

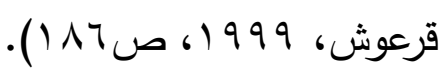

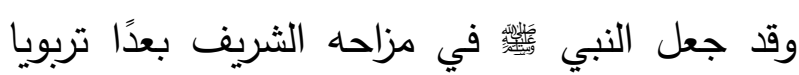
يرشد إلى ضرورة التحلي بالإيثار والسخاء والجود، فقد روى عباد بن مصعب، عن ربيعة بن عثمان

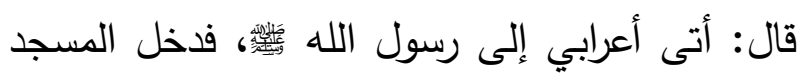

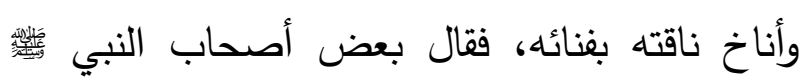

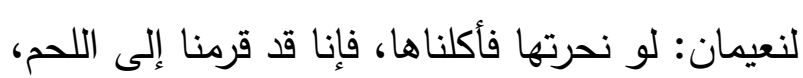

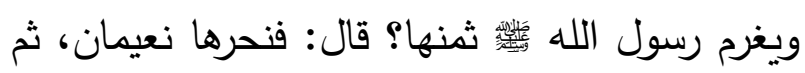
خرج الأعرابي فرأى راحلته، فصاح: واعقراه يا محمد!

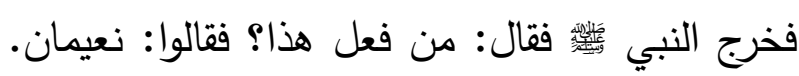

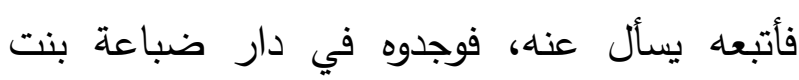
الزبير بن عبد المطلب مستخفياً، فأشار إليه رجل فيله ورفع صوته يقول: ما رأيته يا رسول الله. وأثار

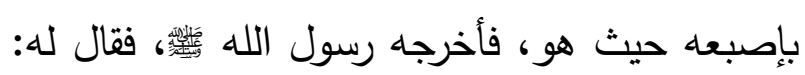

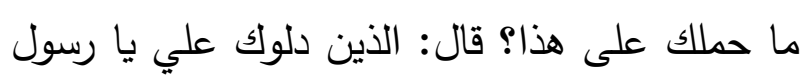

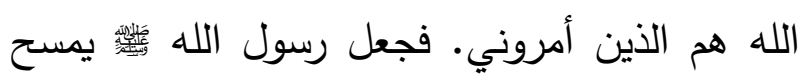
وجها ويضحك، وغرم ثمنها (يوسف بن عبد الله بن

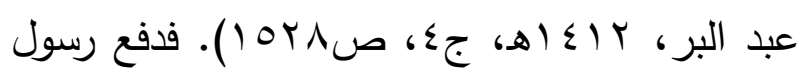

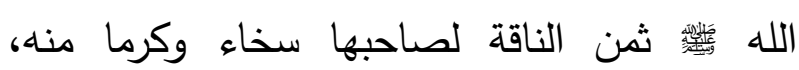
وتطييبا لنفس أصحابه. 


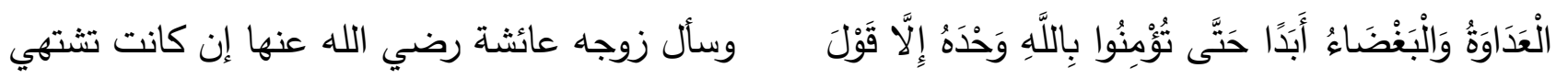

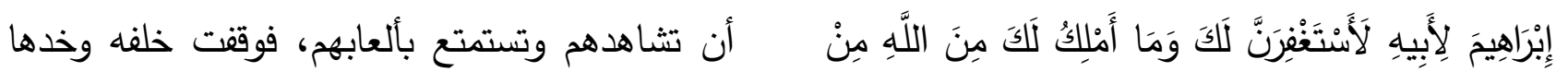

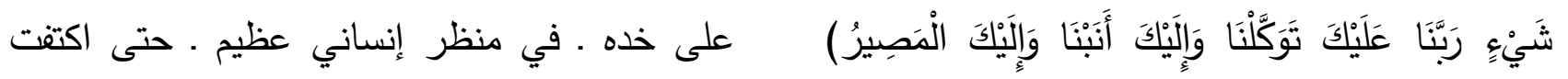

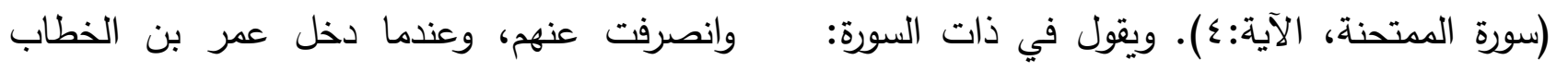

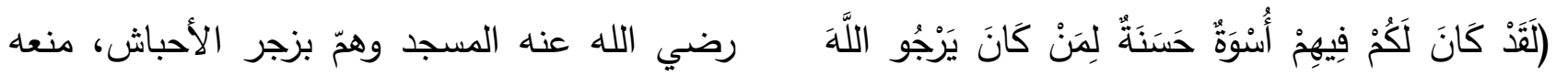

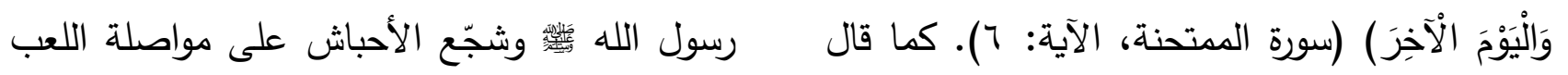

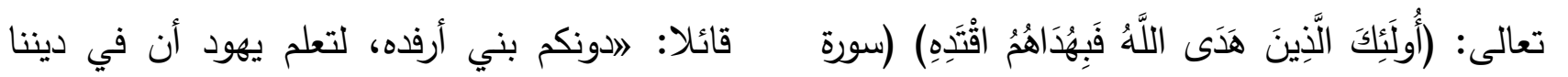

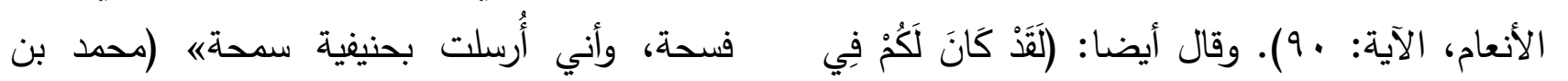

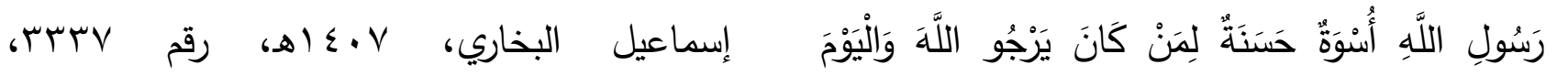

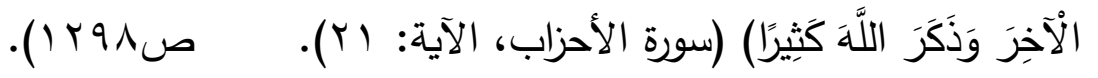

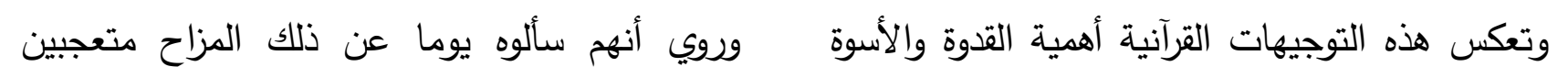

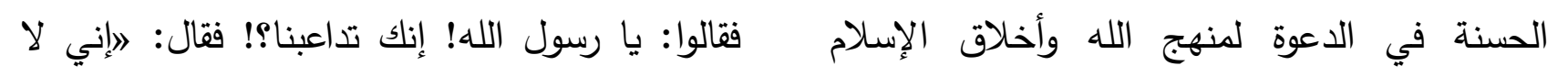

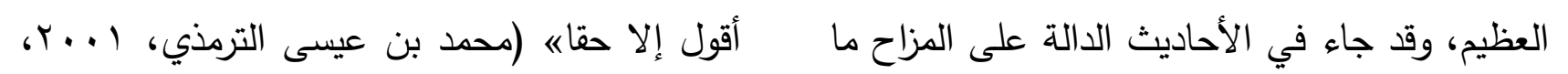

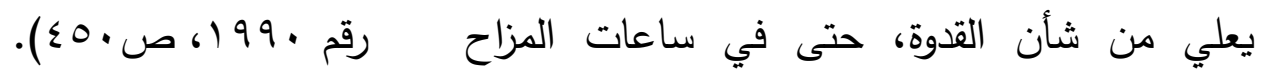

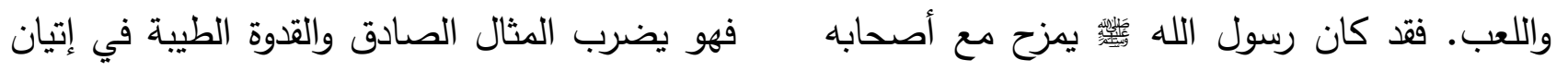
رجالا ونساءً ويداعبهم، ففي حديث عبد الله بن ما يتوافق مع الميول الإنسانية والطبائع البشرية، لكنه

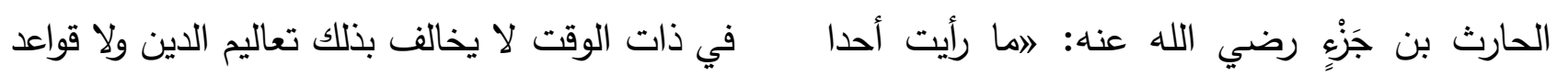

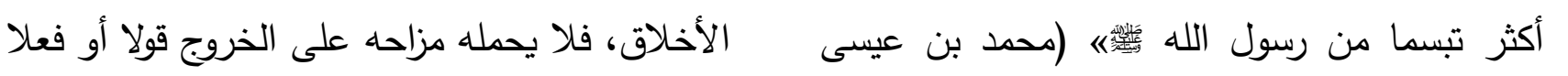

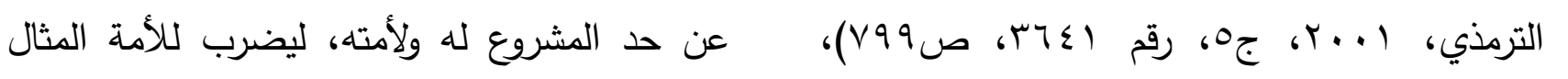

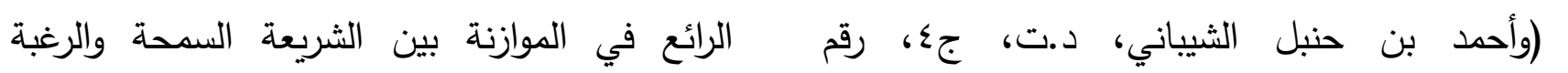

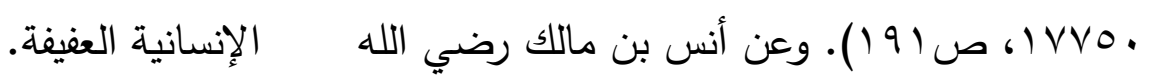

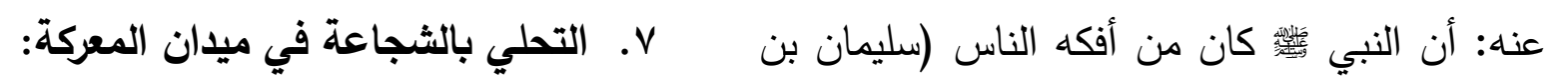

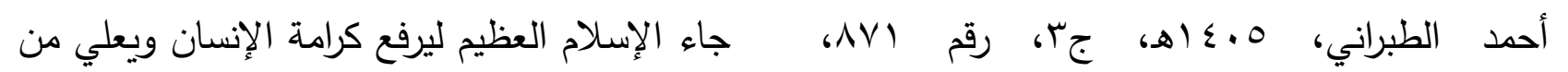

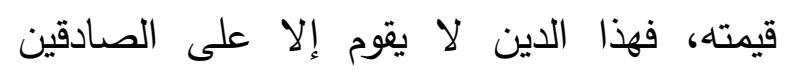

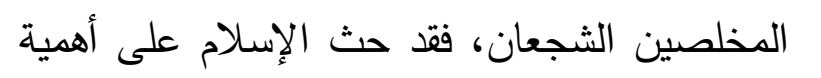

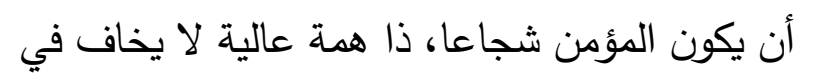

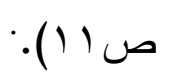

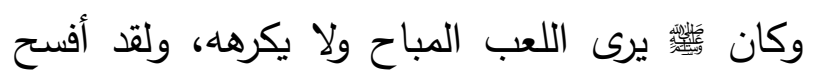
لفرقة من الأحباش ترقص وتغني بمسجد المدينة، 
الله هذه أم سليم معها خنجر! فقال لها رسول الله

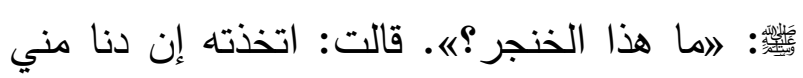
أحد من المشركين بقرت به بطنه. فجعل رسول الله

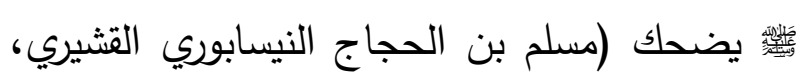

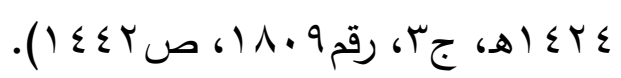

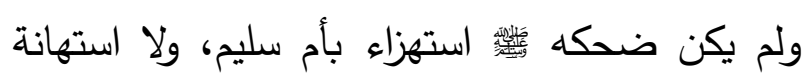

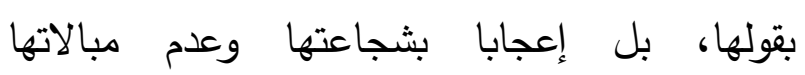

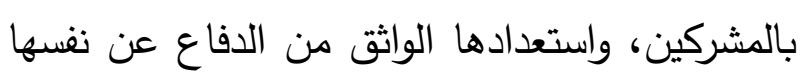
إذا احتاجت إلى ذلك (محمد بن يوسف الكرماني،

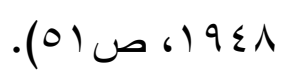

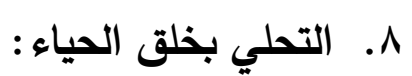

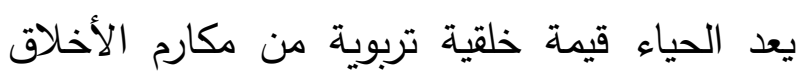

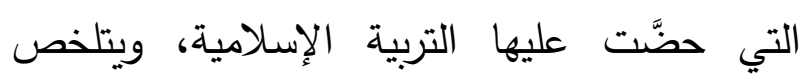
مفهومه في التوبة والحشمة، والحياء في حقيقته: خلق يبعث على ترك القبيح، ويمنع من التقصير في

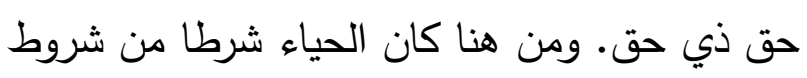
الفعل الخلقي يبعث على ترك القبيح، ويمنع من ون هن التقصير في حق صاحب الحق (محي الدين يحيى

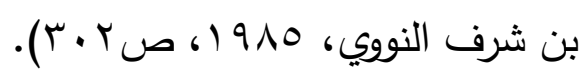

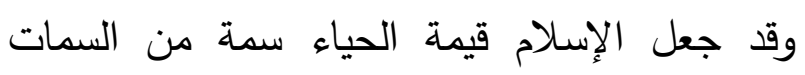

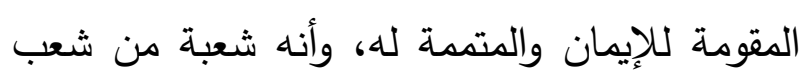
الإيمان، كما ربط الإسلام أيضا بين الحياء وبين طرق الخير كلها، وهذا مصدر من مصادر السعادة والرضوان الذي ضل عنه المعرضون وجافوا طريق الفطرة والتوحيد.
الله لومة لائم، فقال تعالى: (يَا أَيْهَها الَّذَينَ آَتَنُوا إِذَا

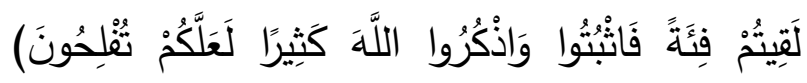

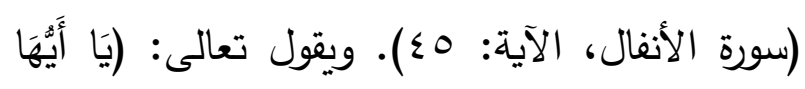

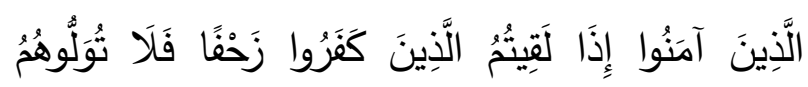

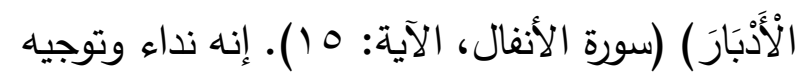
رباني للمؤمنين بالقوة والثجاعة والعزيمة.

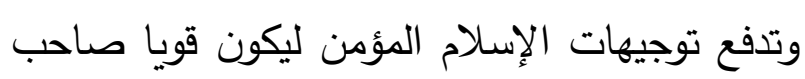

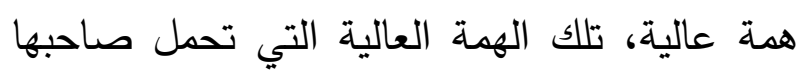

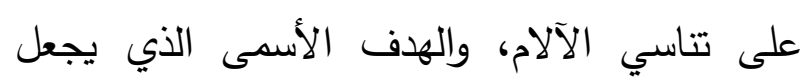

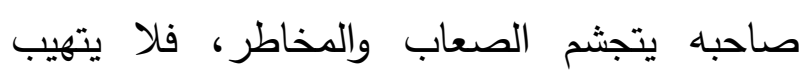
صعود الجبال (محد عبد القادر أبو فارس، د.ت، ص ص1 ( ). وجاء في الحديث الشريف أن رسول الله سيفا يوم أحد فقال من يأخذ هذا السيف؟ فأخذه قوم فجعلوا ينظرون إليه. فقال من يأخذه بحقه؟ فأحجم

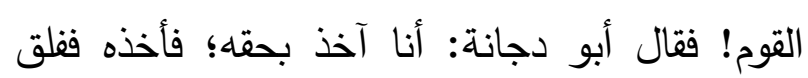

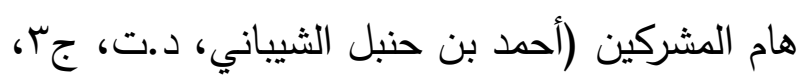

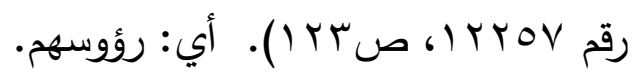
وفي هذا الحديث دلالة واضحة أنه يجوز للمسلم المقاتل أن يظهر قوته وشجاعته في ساحة المعركة أمام عدوه لإرهابه والتأثير على نفسيته التتالية، كما

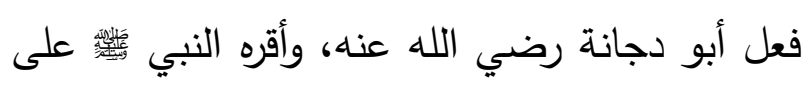

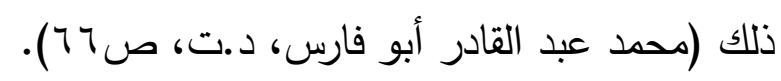

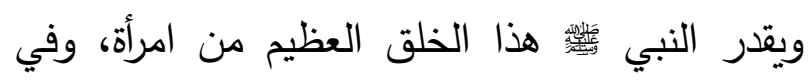

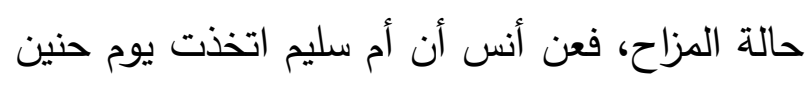

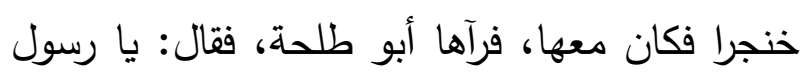


الثالث عن: التأصيل الإسلامي للمزاح، وتكون من

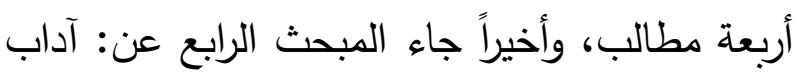
المزاح وأبعاده في الإسلام، وتكون من مطلبين، وكان من أبرز نتائج البحث ما يلي:

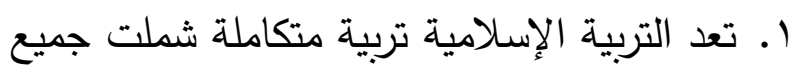

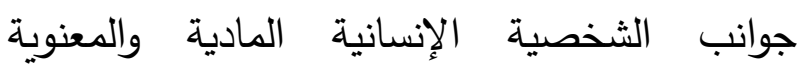
والوجدانية بما تشمله من متغيرات وانفعالات. r. يعد المزاح والمزاح من الجوانب التي تئثر في نئي شخصية الفرد وفي تعامله مع الآخرين، كما أن لهما مردود إيجابي على جوانب النمو المختلفة خاصة النه النفسية إذا تم توظيفهما بصورة سليمة. r. كانت الثقافة الإسلامية أكثر الثقافات ولَعًَا بالمزاح، حتى ظهر فيها على مرِ العصور في صور الإسله مختلفة، وعبرت عنه بمغردات متتوعة، مثل 》الهزل

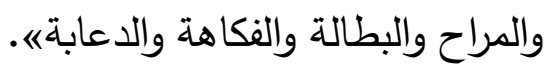

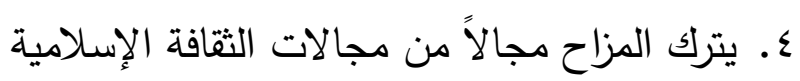
إلا دخله، فهو موجود في الثعر والنثر والمقامة، ولا

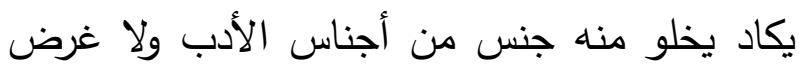

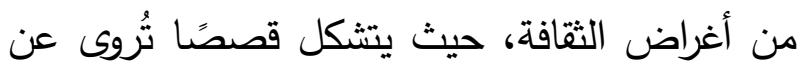
البخلاء، ونوادر في الحمقى والمغفلين، وأخبارًا في سير الأولين، ورواية يرويها راو عن أعرابي. ه. تتعدد سمات الثخصية ما بين سمات وراثية وسمات مكتسبة وسمات مشتركة وسمات سطحية وسمات مصدرية وسمات ديناميكية وسمات قدرة،

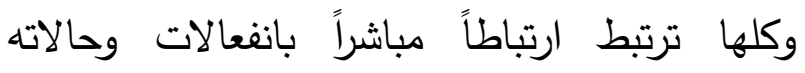
الوجدانية ومن بينها رغبته في المزاح من عدمه برنها
وفي حديث خوات بن جبير لما قال له رسول الله

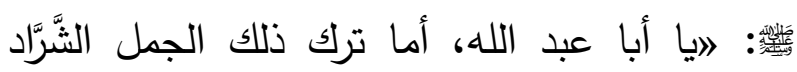
بعد؟!ه. قال: فسكتُّ واستحييتُ، وكنتُ بعد ذلك

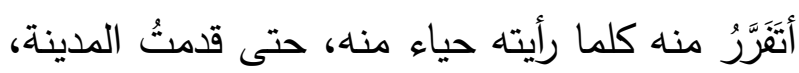
فرآني في المسجد يوما أصلي، فجلس إليّ فطوَّلتُ، فنهاء

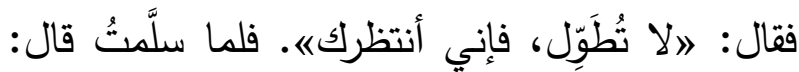
״يا أبا عبد الله، أما ترك ذلك الجمل الثِّراد بعد؟!ه. فقلت: والذي بعثلك بالحق ما شرد منذ أسلمت. فقال:

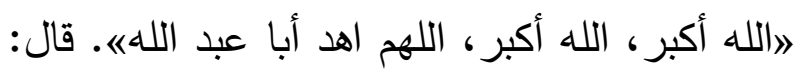
فحسن إسلامه وهداه الله (سليمان بن أحمد الطبراني،

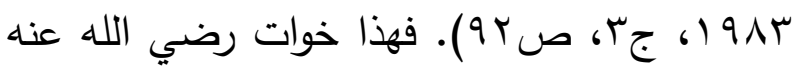
قد سكت عند سؤال الرسول في له عن سبب وقوفه

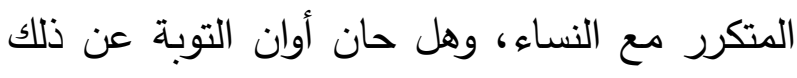

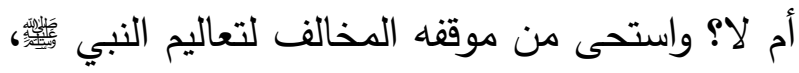
وكان بعد ذلك يتحاشى ملاقاة الرسول مله في الطريق استحياء من ذنبه الذي وقع فيه من قبل (عبد الله بن

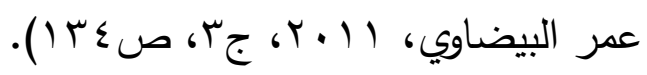

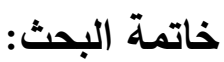
أولاً: النتائج هدف البحث عرض أحكام وآداب المزاح في الشريعة الإسلامية، وتم استخدام المنهج الاستتباطي، وجاء البحث مكوناً من إطار عام، ثم أربعة مباحث وعدة الإنداء مطالب على النحو التالي: المبحث الأول عن: ملامح الثخصية الإنسانية وعلاقتها بالمزاح، وكان المبحث الثاني عن: ضبط بعض المظاهر الانفعالية في الإسلام، وتكون من ثلاثة مطالب، وجاء المبحث 
والطريقة التي يتبعها في المزاح وغير ذلك من تجنب المزاح مع غير المحارم من النساء، استعمال حسن الفعل والقول في المزاح. الأمور المرتبطة به.

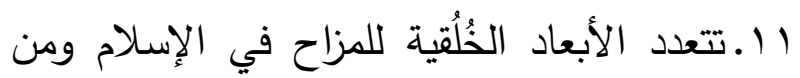

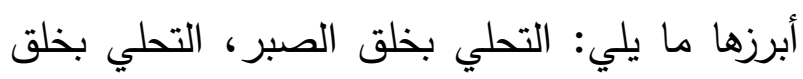

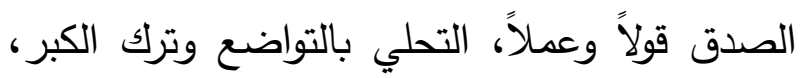

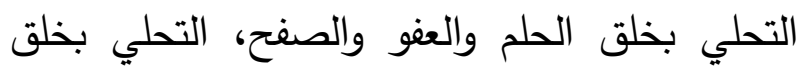
الكرم والبذل والإيثار، تحقيق القدوة الحسنة والنموذج ولج

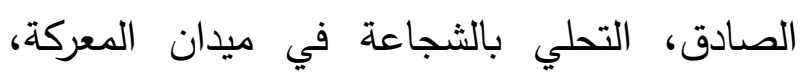
التحلي بخلق الحياء. توصيات البحث: ا ـ ضرورة إخضاع البرامج التي تتضمن مزاحاً

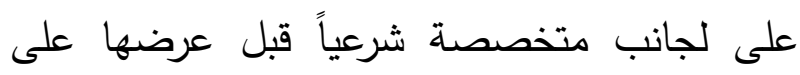
الجمهور r. توجيه الأسرة المسلمة لكيفية تتشئة أبنائها على الالتزام بآداب المزاح وضوابطه في الإسلام.

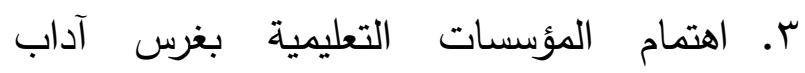
وضوابط المزاح لدى المتعلمين.

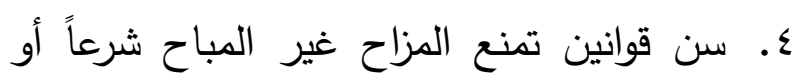
الذي يتضمن إساءة للآخرين أو ترويع لهم. مقترحات البحث: 1. دراسة نقدية للبرامج الكوميدية بوسائل الإعلام المرئية في ضوء الضوابط الشرعية.

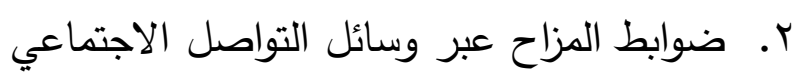
وكيفية تحققها في ضوء الشريعة الإسلامية. r. موقف الفقه الإسلامي من الترويح وأحكامه.
7. تتكون الثخصية الإنسانية من مكونات جسمية بله

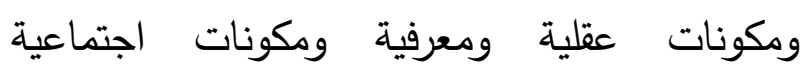

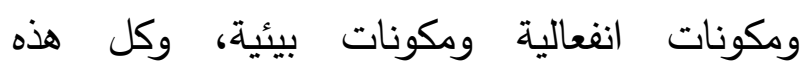

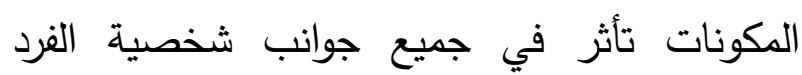
خاصة الوجدانية والانفعالية. V. يمكن وصف الشخصية وصفاً كاملاً من خلال خمسة عوامل أساسية هي: العصابية والانبساط والانفتاح على الخبرة والمقبولية ويقظة الضمير .

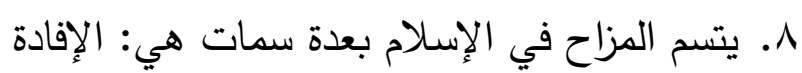

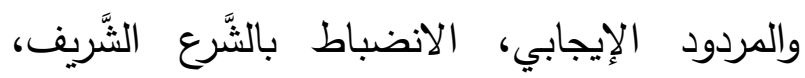

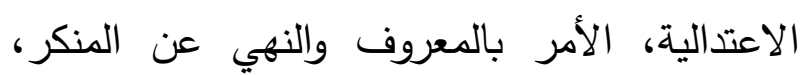
الإشباع، الاختيارية، تحقيق التوازن النفسي.

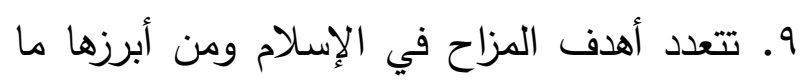

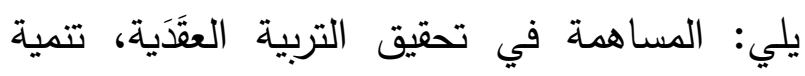
القدرات العقلية، الدحافظة على الصحة الجسمية،

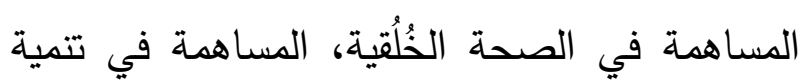
المهارات المعرفية، تحقيق التوافق النفسي السليم،

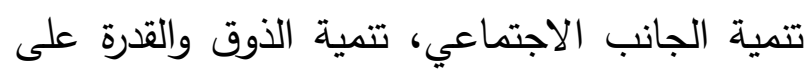

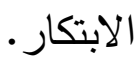
• ا.تتعدد الضوابط التي ينبغي مراعاتها في المزاح

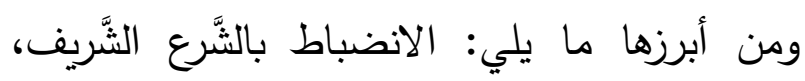

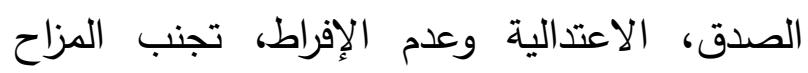
المحرِّك للأحقاد والضغائن، عدم الترويع والتخويف، الاعند 
ماجستير غير منشورة - كلية التربية - جامعة دمشق، 0 ( 10 • ب م.

• ـ.الأنصاري، بدر محمد. (r . . r). المرجع في إ. مقاييس الشخصية، تقنين على المجتمع الكويتي، دار الكتاب الحديث، القاهرة. ا ا. البيضاوي (عبد الله بن عمر): تحفة الأبرار

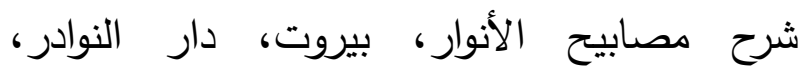
. 11 ץ ا. البيهقي (أحمد بن الحسين): السنن الكبرى، حيدر آباد، المعارف النظامية، ؟ ؟ب آ هـ. س ا ـالترمذي (محمد بن عيسى): الجامع المختصر،

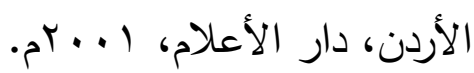
ع ا ـ الترمذي (محمد بن عيسى): الشمائل المحمدية، بيروت، مؤسسة الكتب الثقافية، ب إ؛ اهـ. ما ـ تهاني عبد السلام: أسس الترويح، القاهرة، دار

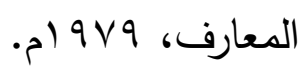
ד1.الجاحظ (عمرو بن بحر)، الحيوان، جاج، بيروت، دار ومكتبة الهلال، ب99 أم. IV مكتبة الفلاح، 1 . ع 1 هـ. 1 ا. حسن شحاتة: النشاط المدرسي، القاهرة، الدار المصرية اللبنانية، • (1 أ هـ. 9 1. حسن عبد الغني أبو غدة: المزاح في الإسلام، سلسلة دعوة الحق، العدد جابك، السنة الثالثة والعشرون، إدارة الدعوة والتعليم، الرياض، ه ه . . بم.
ع. دور الأسرة في غرس آداب المزاح وضوابطه لاى أبنائها من منظور شرعي.

\section{قائمة المراجع}

ا. إبراهيم أنيس: المعجم الوسيط، طب، بيروت، دار إحياء التراث العربي، د.ت. r. الأبشيهي (محمد بن أحمد): المستطرف في كل فن مستظرف، القاهرة، التوفيقية، د. ت. r. ابن حجر (أحمد بن علي): فتح الباري شرح صحيح البخاري، بيروت، دار المعرفة، ا . . بم. ء. ابن عبد البر (يوسف بن عبد الله): الاستيعاب في معرفة الأصحاب، بيروت، دار الجيل، باء أه. ه. ابن قيم الجوزية (محمد بن أبي بكر): مدارج السالكين، ج ج، بيروت، دار الكتاب العربي، •) $9 \vee$ 7. ابن منظور (محمد بن مكرم): لسان العرب، بيروت، دار صادر ، د. ت. V. أبو داود (سليمان بن الأشعث): السنن، بيروت، دار الكتاب العربي، 991 (م. ^. أحمد عبد اللطيف وحيد: علم النفس الاجتماعي. عمان، دار المسرة للنشر والتوزيع

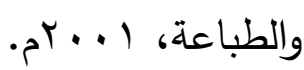

9. أنس وحمد شحاتة: التعاطف والنرجسية وعلاقتهما بالرضا المهني لدى عينة من المرشدين النفسيين في مدارس محافظة دمشق الرسمية- رسالة 
• r.الحسين بن عبد الله الطيبي: الكاشف عن طلاب الجامعة، كلية التربية، جامعة الزقازيق،

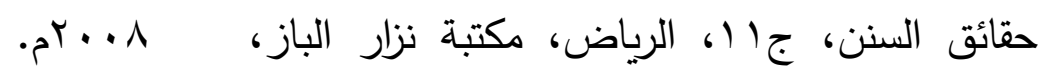

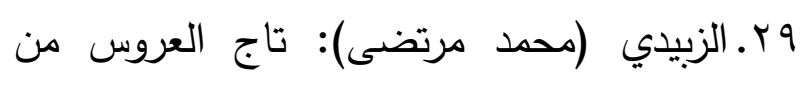
جواهر القاموس، تحقيق: مصطفى حجازي، بيروت،

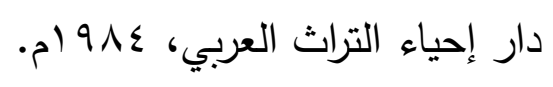

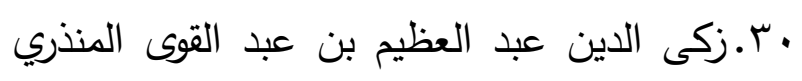
(الإمام): الترغيب والترهيب، القاهرة، دار الحديث-

اس.سعيد إسماعيل علي: أصول التربية الإسلامية،

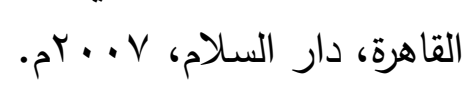

rr.شاكر عبد الحميد: الفكاهة والضحك... دعوة للتفاؤل، الكويت، المجلس الوطني للثقافة والفنون

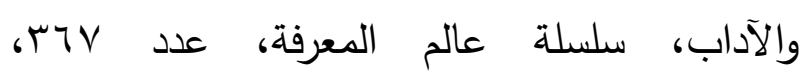

$$
\text { فبراير r + . rم. }
$$

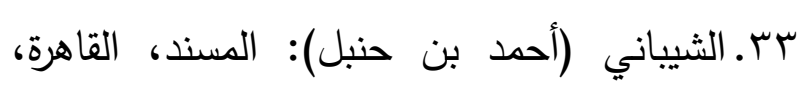

$$
\text { مؤسسة قرطبة، د.ت. }
$$

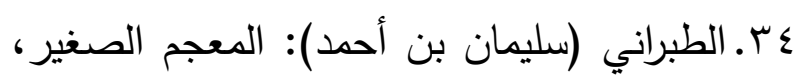

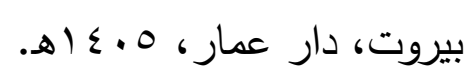

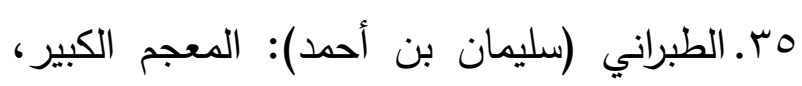

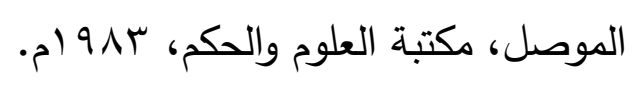

צr.طه، فرج عبد القادر: موسوعة علم النفس ولته

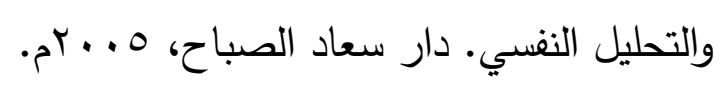

rV

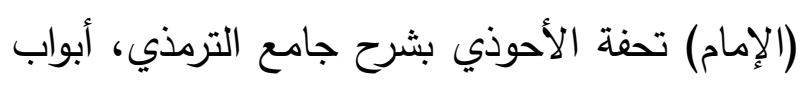

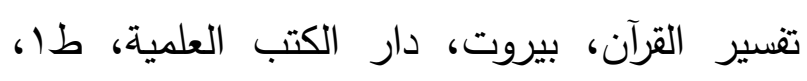

.199.
. $199 \mathrm{~V}$

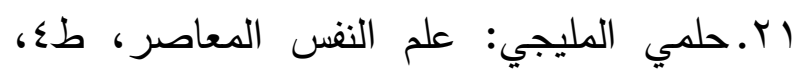
الإسكندرية، دار المعرفة الجامعية، ل ...بام. r..حمادي صمّود، بلاغة الهزل وقضية الأجناس

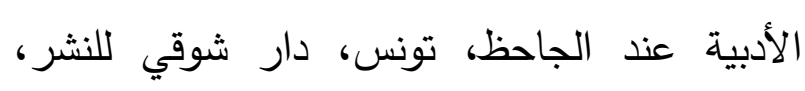
. بr.حمد الله حافظ محمد إبراهيم: الأبعاد التربوية

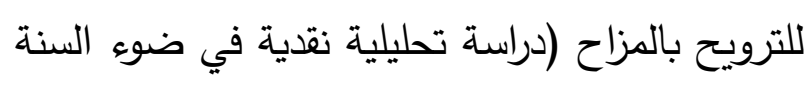

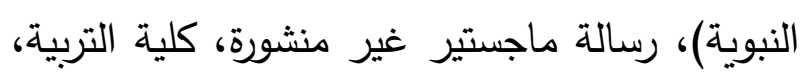

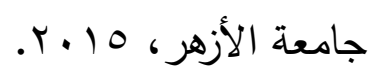
؟r.خالد فهر العودة: الترويح التربوي. رؤية إسلامية، الرياض، دار المسلم للنشر والتوزيع، عا إله Or.ختام عبد الله غنام: السمات الشخصية والولاء التتظيمي لاعى معلمات المرحلة الأساسية في المدارس الحكومية في محافظة نابلس، رسالة جامعية غير منشورة، جامعة النجاح الوطنية، نابلس،

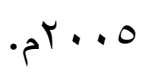
דr.الرازي (محمد بن أبي بكر): مختار الهِّحاح،

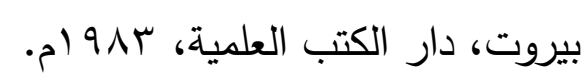
جه

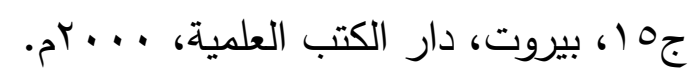

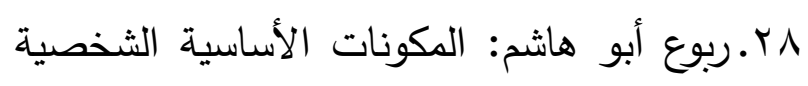

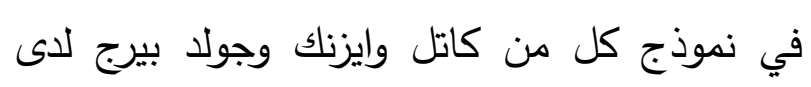


\& V بيروت، مؤسسة الرسالة، 9 أم أ. ^ــ.فواز بن مبيريك حماد الصعيدي: الأساليب التربوية النبوية المتبعة في التوجيه وتعديل السلوك وكيفية تفعيلها مع طلاب المرحلة الثانوية بنين (تصور مقترح)، رسالة ماجستير غير منشورة، كلية التربية، جامعة أم القرى، 9 . . ب م. 9ء. فيليب فنكس: فلسفة التربية، القاهرة، دار النهضة العربية، ب19 ام. •0.قاسم غنى: تاريخ التصوف الإسلامي، القاهرة،

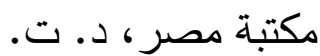

1. القرطبي (محمد بن أحمد): الجامع لأحكام القرآن، بيروت، دار الفكر ، 9NV (م. r.Or كايد قرعوش: التربية الأخلاق في الإسلام، عمان، دار المناهج، 999 (م. rه. الكرماني (محمد بن يوسف): الكواكب الدراري شرح صحيح البخاري، ج"، القاهرة، مكتبة مصطفى

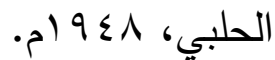
؟ه. مأمون المبيض، الذكاء العاطفي والصحة العاطفية، المكتب الإسلامي، بيروت، د.ت. 0. محمد الحمامى، وعايدة عبد العزيز: الترويح بين النظرية والتطبيق، بيروت، مركز الكتاب للنشر، . $) 9.0$ 07.محمد الغزالي: جدد حياتك. الإسكندرية، دار

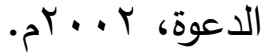

^ץ. عبد الله ناصر السدحان: قضاء وقت الفراغ وعلاقته بانحراف الأحداث، رسالة ماجستير غير منشورة، المعهد العالي اللعنية، الرياض، بـ9 99 (م. وس. عبد النبي عبد الرسول: جامع العلوم في اصطلاحات الفنون، جب، حيدر آباد، دائرة

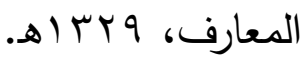
• ع.عجاج خيري: الذكاء الوجداني، الأسس والتطبيقات، مكتبة زهران الشرق، القاهرة، 0 ا • بم. اءـ. عدنان جلوان: دليل التربية الرياضية، المدينة المنورة، دار التراث، 9 ، ع ا هـ. rء. العظيم آبادي (محمد بن شمس الحق): عون المعبود شرح أبي داود، بيروت، دار الكتب العلمية، . () 10 بــ العيني (محمود بن أحمد): عمدة القاري بشرح صحيح البخاري، جrr، بيروت، دار الكتب العلمية،

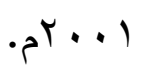

ـــ غازي بن محمد بن دميس القرني: أساليب النبي صلى الله عليه وسلم في عملية الضبط الاجتماعي وتطبيقاتها في الواقع المعاصر ، رسالة ماجستير غير

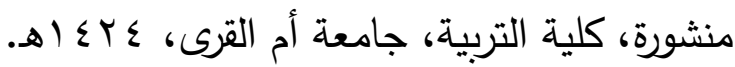
هـ ـالغزالي (محمد بن محمد): إحياء علوم الدين، جدة، دار المنهاج للنشر والتوزيع، بrع إ هـ. جــ.الغزي (محمد بن محمد): المراح في المزاح، تحقيق: السيد الجميلي، القاهرة، مكتبة الثقافة الدينية، .2) 917 
77.محمد عثمان نجاتي: القرآن وعلم النفس،

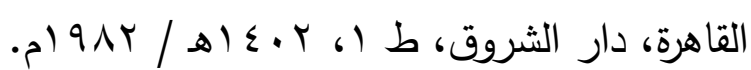
TV. محمد علي الصابوني: صفوة التفاسير، دمشق، مكتبة الغزالي، 99 مبا (هـ. 1..محمد عمارة: المنهاج النبوي في المداعبة والمزاح، مجلة حراء، مجلة فصلية تصدر عن مركز النيل بالقاهرة، العدد ب ا، ^ . . بم. 7. 9 . محمود أبو دف، ومحمد الأغا: التلوث الثقافي لاى الشباب في المجتمع الفلسطيني ودور التربية في مواجهته. مجلة الجامعة الإسلامية. موه. ع ع.

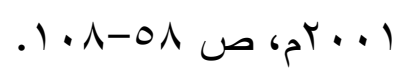

• V. . محمود حب الله: الحياة الوجدانية والعقيدة الدينية، (علم النفس الاجتماعي والديني) القاهرة، دار إحياء الكتب العربية، 19 أهـ. ا.V. محي الدين يحي بن شرف النووي: المنهاج في شرح صحيح مسلم، بيت الأفكار الدولية للتوزيع والنشر • الرياض، (د-ت). VY.VY بيروت: دار الكتاب، ع \& اهـ. rV. الموصلي (أحمد بن علي)، المسند، ج^، دار المأمون للتراث، دمشق، ع 9 (م. أ. ع V. النووي (يحيى بن شرف): رياض الصالحين، بيروت، دار الكتب العلمية، 9 ام (م. 0. هناء يحيى أبو شهبة: السنة النبوية وتوجيه المسلم إلى الصحة النفسية، (مؤتمر السنة النبوية في ov.ov محمد بن إسماعيل البخاري: صحيح البخاري، بيروت. دار ابن كثير • V • ع أهـ. هـ.محمد بن جرير الطبري (الإمام أبى جعفر):

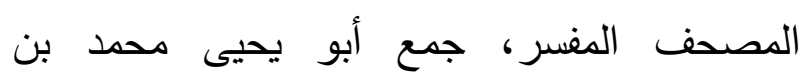
صمادح النجيبى، القاهرة - دار الغد العربي . 994 هو. محمد بن يزيد ابن ماجة: سنن ابن ماجة، تحقيق محمد فؤاد عبد الباقي، بيروت. دار إحياء التراث العربي. • 7. محمد خليفة إسماعيل: أثر لعب المعلمة مع الطفل على الامتثال لدى الأطفال الصغار، مجلة

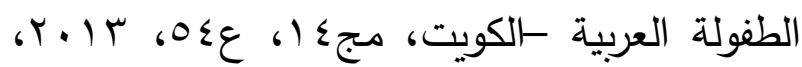

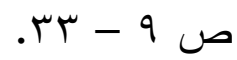
آ. محمد رشيد رضا: تقسير القرآن الحكيم، المشتهر بتفسير المنار، القاهرة، دار المنار، طس، s ITV r7. محمد شحات الخطيب: أصول التربية الإسلامية، طب، الرياض، دار الخريجي للنشر

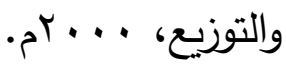
با..محمد صالح العلوي: خطاب النبي صلى الله عليه وسلم للطفل المسلم وتطبيقاته التربوية. رسالة

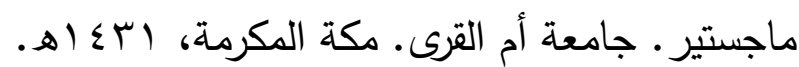
ـا.محمد عبد القادر أبو فارس: تزكية النفس، القاهرة، بيروت، دار الفرقان للنشر، د. ت. 07. محمد عبد الله: مدخل إلى الصحة النفية،

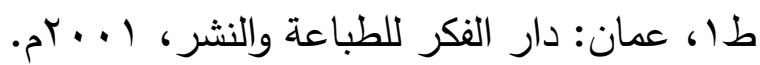


79. Crow, Lester D. (1968). Psychology of Human Adjustment. New York: Alfred. A. Knopf.

80. Rieger A. \& MC Grail, J. P. (2013). Coping humor and family functioning in parents of children with disabilities. Rehabilitation Psychology, 58(1), 89-97.

81. Schultz, D. P \& Schultz, S. E. (2005). Theories of Personality. Belmont, CA: Thomson Wadsworth.

82. Turner, Diane and Creco, Thelma (1998). The Personality Compass. Boston: Element Books.
الدراسات المعاصرة، جامعة اليرموك، إربد، الأردن، $. \varepsilon-11,+r \cdot v$ T. VT هيام عبود: بعض السمات الشخصية لدى الممارسات وغير الممارسات للأنشطة الرياضية، بحث منشور، مركز أبحاث الطفولة والأمومة، جامعة ديالي، · ( · 'بم. . يحيى بسيوني مصطفى: البدائل الإسلامية لوسائل الترويح المعاصرة (عرض الكتاب في مقال)، جr (ا، بيروت، عالم الكتب، ب99 99 (م. 78. Block, J. (2001) The Five-Factor Approach to Personality Description 5years Later, Journal of Research in Personality (35) 98-107. 


\title{
Provisions and Etiquette of Humor in Islamic Sharia
}

\author{
D.ENSAF HAMZAH ALSHAREEF \\ Co-Professor \\ Department of General Studies - College of Arts and Humanities \\ King Abdulaziz University
}

\begin{abstract}
Islamic Sharia, and used the deductive method. The research consisted of a general framework that included the introduction, the research problem, questions, objectives, methodology, and previous studies, and then four investigations and several demands. The first topic is features of the human personality and its relationship to humor, and it consists of three demands: The first demand is the concept of personality traits, the second demand is the personality components, and the third demand is personality styles and its five factors. The second topic discussed controlling some emotional aspects in Islam, and consisted of three demands: The first demand is emotional eloquence, the second demand is the call to express feelings, and the third demand is educating Muslim on emotional control and emotional independence. The third topic discussed the Islamic founding of humor, and consisted of four demands: The first demand is the concept of humor in language and convention, the second demand is characteristics of humor in Islam, the third demand is aims of joke in Islam, and the fourth demand is forms of the Prophet joking (peace and blessings be upon him). Finally, the fourth topic discussed the etiquette of humor and its dimensions in Islam, it consisted of two demands: The first demand is controls that should be taken into account in humor, the second demand is the moral dimensions of joking. The research concluded with the most prominent results, recommendations and suggestions, then a list of references.
\end{abstract}

Key words: Controls - Etiquette - Recreation - Humor - Emotions. 